Prepared in cooperation with the Colorado Department of Iransportation

\title{
Peak Discharge, Flood Frequency, and Peak Stage of Floods on Big Cottonwood Greek at U.S. Highway 50 Near Coaldale, Colorado, and Fountain Creek below U.S. Highway 24 in Colorado Springs, Colorado, 2016
}

Scientific Unvestigations Peport $2017 \times 5107$

U.S. Department of the-interior. U.S. Geologital su ver:

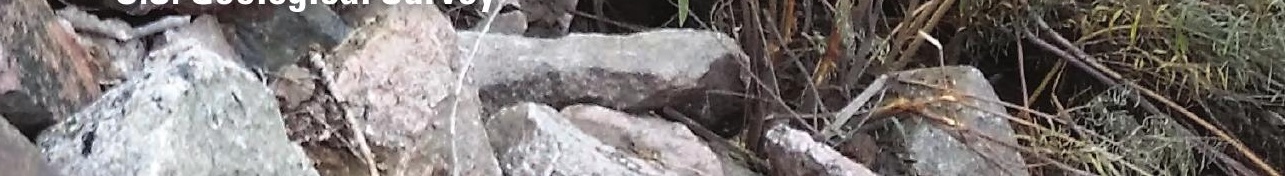


Cover. Looking upstream at Big Cottonwood Creek from US Highway 50 near Coaldale, Colorado with evidence of the August 23, 2016 flood visible. Photograph by Michael R. Stevens. 


\section{Peak Discharge, Flood Frequency, and Peak Stage of Floods on Big Cottonwood Creek at U.S. Highway 50 Near Coaldale, Colorado, and Fountain Creek below U.S. Highway 24 in Colorado Springs, Colorado, 2016}

By Michael S. Kohn, Michael R. Stevens, Amanullah Mommandi, and Aziz R. Khan

Prepared in cooperation with the Colorado Department of Transportation

Scientific Investigations Report 2017-5107 


\title{
U.S. Department of the Interior \\ RYAN K. ZINKE, Secretary
}

\section{U.S. Geological Survey William H. Werkheiser, Deputy Director exercising the authority of the Director}

\author{
U.S. Geological Survey, Reston, Virginia: 2017
}

For more information on the USGS - the Federal source for science about the Earth, its natural and living resources, natural hazards, and the environment-visit https://www.usgs.gov or call 1-888-ASK-USGS.

For an overview of USGS information products, including maps, imagery, and publications, visit https://store.usgs.gov.

Any use of trade, firm, or product names is for descriptive purposes only and does not imply endorsement by the U.S. Government.

Although this information product, for the most part, is in the public domain, it also may contain copyrighted materials as noted in the text. Permission to reproduce copyrighted items must be secured from the copyright owner.

Suggested citation:

Kohn, M.S., Stevens, M.R., Mommandi, Amanullah, and Khan, A.R., 2017, Peak discharge, flood frequency, and peak stage of floods on Big Cottonwood Creek at U.S. Highway 50 near Coaldale, Colorado, and Fountain Creek below U.S. Highway 24 in Colorado Springs, Colorado, 2016: U.S. Geological Survey Scientific Investigations Report 2017-5107, 58 p., https://doi.org/10.3133/sir20175107.

ISSN 2328-0328 (online) 


\section{Acknowledgments}

The authors would like to thank Mark Smith and Zachary Martin of the U.S. Geological Survey (USGS) for their constructive comments as technical reviewers. The authors would also like to thank William Payne, Krystal Brown, Erica Rau, and Ivan Valles of the USGS for their contributions during the field data collection.

Tony Anderson of the National Weather Service provided assistance identifying and compiling precipitation data that enriched the content of this report.

\section{Contents}

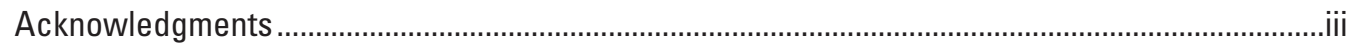

Abstract

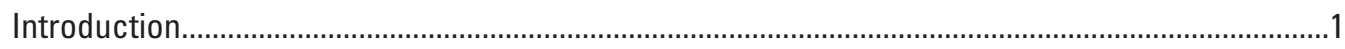

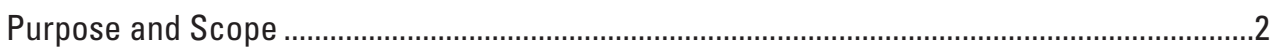

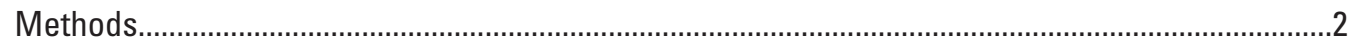

High-Water Mark and Cross Section Surveys ......................................................................

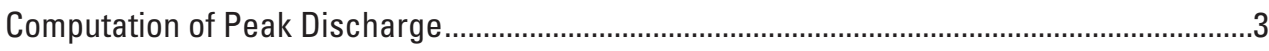

Flood-Frequency Analysis of Peak Discharge ........................................................................

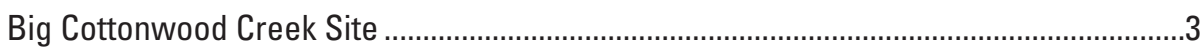

Fountain Creek Site .................................................................................................

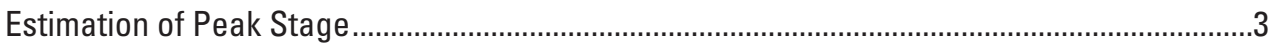

Big Cottonwood Creek at U.S. Highway 50 near Coaldale, Colorado ...............................................

Description of the Study Area ..............................................................................................

High-Water Mark and Cross Section Surveys .................................................................. 6

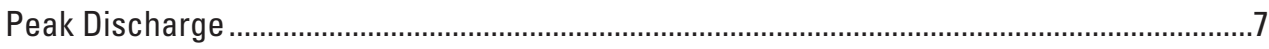

Hydraulic Modeling Results of Peak Discharge .............................................................

Evaluation and Uncertainty Analysis of Peak Discharge _...............................................9

Flood-Frequency Analysis of Peak Discharge ......................................................................

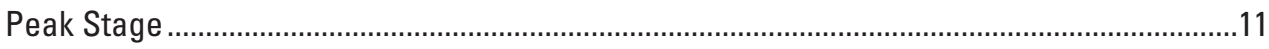

Fountain Creek below U.S. Highway 24 in Colorado Springs, Colorado ...........................................11

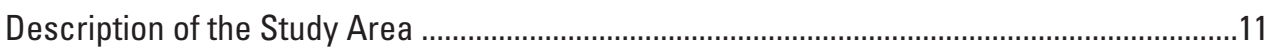

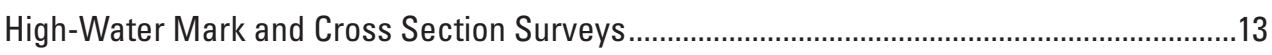

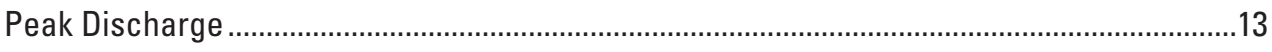

Hydraulic Modeling Results of Peak Discharge ............................................................18

Evaluation and Uncertainty Analysis of Peak Discharge............................................18

Flood Frequency of Peak Discharge ................................................................................2

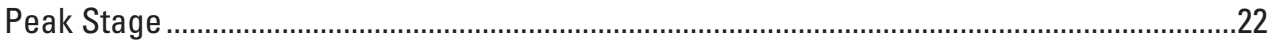

Summary

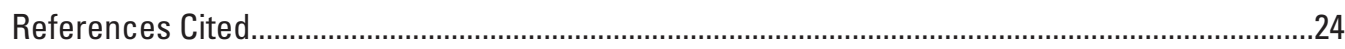

Appendix 1. Survey field Notes from Big Cottonwood Creek at U.S. Highway 50 near Coaldale, Colorado .......................................................................................................... 
Appendix 2. Photos of High-Water Marks from Big Cottonwood Creek at U.S. Highway 50 near Coaldale, Colorado link

Appendix 3. Photos of Cross Sections from Big Cottonwood Creek at U.S. Highway 50 near Coaldale, Colorado link

Appendix 4. Manning Roughness Coefficient (n) Assignments and Channel Conditions for the Cross Sections on Big Cottonwood Creek at U.S. Highway 50 near Coaldale, Colorado.

Appendix 5. Plots Showing the Cross Sections with Manning Roughness Coefficients ( $\mathrm{n}$ ) Assignments for Big Cottonwood Creek at U.S. Highway 50 near Coaldale, Colorado......38

Appendix 6. Survey Field Notes from Fountain Creek below U.S. Highway 24 in Colorado Springs, Colorado

Appendix 7. Photos of High-Water Marks from Fountain Creek below U.S. Highway 24 in Colorado Springs, Colorado... link

Appendix 8. Photos of Cross Sections from Fountain Creek below U.S. Highway 24 in Colorado Springs, Colorado. link

Appendix 9. Manning Roughness Coefficient (n) Assignments and Channel Conditions for the Cross Sections on Fountain Creek below U.S. Highway 24 in Colorado Springs, Colorado.

Appendix 10. Plots Showing the Cross Sections with Manning Roughness Coefficients (n) Assignments for Fountain Creek below U.S. Highway 24 in Colorado Springs, Colorado.

\section{Figures}

1. Location of the Big Cottonwood Creek watershed and August 23, 2016, storm near Coaldale, Colorado

2. Location of the site at the mouth of Big Cottonwood Creek at U.S. Highway 50 near Coaldale, Colorado

3. Plan view of the site showing the left and right bank high-water marks (HWMs) and cross sections for Big Cottonwood Creek at U.S. Highway 50 near Coaldale, Colorado; generated using the Slope-Area Computation Graphical User Interface ........6

4. Profile view of the left and right bank high-water marks (HWMs) and cross sections for Big Cottonwood Creek at U.S. Highway 50 near Coaldale, Colorado; generated using the Slope-Area Computation Graphical User Interface.

5. The Slope-Area Computation Graphical User Interface (SACGUI) model output summary for Big Cottonwood Creek at U.S. Highway 50 near Coaldale, Colorado.........10

6. The StreamStats output summary for Big Cottonwood Creek at U.S. Highway 50 near Coaldale, Colorado.

7. The envelope curve for Region 13 from Crippen and Bue (1977) with the flood of August 23, 2016, on Big Cottonwood Creek at U.S. Highway 50 near Coaldale, Colorado

8. Location of the Fountain Creek watershed and August 29, 2016, storm in Colorado Springs, Colorado

9. Location of the site for Fountain Creek below U.S. Highway 24 in Colorado Springs, Colorado

10. Plan view of the site showing the left and right bank high-water marks (HWMs) and cross sections for Fountain Creek below U.S. Highway 24 in Colorado Springs, Colorado; generated from the Slope-Area Computation Graphical User Interface........17 
11. Profile view of the left and right bank high-water marks (HWMs) and cross sections for Fountain Creek below U.S. Highway 24 in Colorado Springs, Colorado; generated using the Slope-Area Computation Graphical User Interface........................19

12. The Slope-Area Computation Graphical User Interface (SACGUI) model output summary for Fountain Creek below U.S. Highway 24 in Colorado Springs, Colorado ....20

13. The PeakFQ output summary for Fountain Creek below U.S. Highway 24 in Colorado Springs, Colorado

14. The envelope curve for Region 12 from Crippen and Bue (1977) with the flood of August 29, 2016, on Fountain Creek below U.S. Highway 24 in Colorado Springs, Colorado.

15. The current (2017) stage-discharge rating for the U.S. Geological Survey streamgage 07105530 with the August 29, 2016, flood at Fountain Creek below U.S. Highway 24 in Colorado Springs, Colorado

1-1. The field notes from the September 20, 2016, survey on Big Cottonwood Creek at U.S. Highway 50 near Coaldale, Colorado

4-1. The Manning roughness coefficient ( $\mathrm{n}$ ) assignment for cross section 1 on Big Cottonwood Creek at U.S. Highway 50 near Coaldale, Colorado

4-2. The Manning roughness coefficient ( $\mathrm{n}$ ) assignment for cross section 2 on Big Cottonwood Creek at U.S. Highway 50 near Coaldale, Colorado

4-3. The Manning roughness coefficient ( $\mathrm{n}$ ) assignment for cross section 3 on Big Cottonwood Creek at U.S. Highway 50 near Coaldale, Colorado

4-4. The Manning roughness coefficient ( $\mathrm{n}$ ) assignment for cross section 4 on Big Cottonwood Creek at U.S. Highway 50 near Coaldale, Colorado

4-5. The Manning roughness coefficient ( $\mathrm{n}$ ) assignment for cross section 5 on Big Cottonwood Creek at U.S. Highway 50 near Coaldale, Colorado

4-6. The Manning roughness coefficient ( $n$ ) assignment worksheet using the Cowan method, page 1

4-7. The Manning roughness coefficient ( $n$ ) assignment worksheet using the Cowan method, page 2 .

5-1. Cross section 1 with the Manning roughness coefficient (n) assignment for Big Cottonwood Creek at U.S. Highway 50 near Coaldale, Colorado; generated from the Slope-Area Computation Graphical User Interface. [X1, cross section 1; 0 , discharge; ft3/s, cubic foot per second; K, conveyance; Vel., velocity; ft/s, foot per second]....

5-2. Cross section 2 with the Manning roughness coefficient (n) assignment for Big Cottonwood Creek at U.S. Highway 50 near Coaldale, Colorado; generated from the Slope-Area Computation Graphical User Interface.

5-3. Cross section 3 with the Manning roughness coefficient (n) assignment for Big Cottonwood Creek at U.S. Highway 50 near Coaldale, Colorado; generated from the Slope-Area Computation Graphical User Interface.

5-4. Cross section 4 with the Manning roughness coefficient (n) assignment for Big Cottonwood Creek at U.S. Highway 50 near Coaldale, Colorado; generated from the Slope-Area Computation Graphical User Interface.

5-5. Cross section 5 with the Manning roughness coefficient ( $\mathrm{n}$ ) assignment for Big Cottonwood Creek at U.S. Highway 50 near Coaldale, Colorado; generated from the Slope-Area Computation Graphical User Interface.

6-1. The field notes from the September 21, 2016, survey for Fountain Creek below U.S. Highway 24 in Colorado Springs, Colorado...

9-1. The Manning roughness coefficient ( $n$ ) assignments for cross section 1 on Fountain Creek below U.S. Highway 24 in Colorado Springs, Colorado 
9-2. The Manning roughness coefficient ( $\mathrm{n}$ ) assignments for cross section 2 on Fountain Creek below U.S. Highway 24 in Colorado Springs, Colorado.

9-3. The Manning roughness coefficient ( $\mathrm{n}$ ) assignments for cross section 3 on Fountain Creek below U.S. Highway 24 in Colorado Springs, Colorado.

9-4. The Manning roughness coefficient ( $\mathrm{n}$ ) assignments for cross section 4 on Fountain Creek below U.S. Highway 24 in Colorado Springs, Colorado.

9-5. The Manning roughness coefficient ( $\mathrm{n}$ ) assignment for cross section 5 on Fountain Creek below U.S. Highway 24 in Colorado Springs, Colorado

9-6. The Manning roughness coefficient (n) assignment worksheet using the Cowan method, page 1

9-7. The Manning roughness coefficient ( $n$ ) assignment worksheet using the Cowan method, page 2

10-1. Cross section 1 with the Manning roughness coefficient (n) assignment for Fountain Creek below U.S. Highway 24 in Colorado Springs, Colorado; generated from the Slope-Area Computation Graphical User Interface.

10-2. Cross section 2 with the Manning roughness coefficient (n) assignment for Fountain Creek below U.S. Highway 24 in Colorado Springs, Colorado; generated from the Slope-Area Computation Graphical User Interface.

10-3. Cross section 3 with the Manning roughness coefficient (n) assignment for Fountain Creek below U.S. Highway 24 in Colorado Springs, Colorado; generated from the Slope-Area Computation Graphical User Interface.

10-4. Cross section 4 with the Manning roughness coefficient (n) assignment for Fountain Creek below U.S. Highway 24 in Colorado Springs, Colorado; generated from the Slope-Area Computation Graphical User Interface.

10-5. Cross section 5 with the Manning roughness coefficient ( $\mathrm{n}$ ) assignment for Fountain Creek below U.S. Highway 24 in Colorado Springs, Colorado; generated from the Slope-Area Computation Graphical User Interface.

\section{Tables}

1. Summary of the 49 high-water marks collected at Big Cottonwood Creek at US Highway 50 near Coaldale, Colo. and were used to determine the peak discharge for the August 23, 2016 flood.

2. The Manning roughness coefficient and cross section condition for all cross sections on Big Cottonwood Creek at U.S. Highway 50 near Coaldale, Colorado.

3. Summary of the $\mathbf{1 0 2}$ high-water marks collected at Fountain Creek below US Highway 24 in Colorado Springs, Colo. and were used to determine the peak discharge for the August 29, 2016 flood.

4. The Manning roughness coefficient and cross section conditon for all cross sections at Fountain Creek below U.S. Highway 24 in Colorado Springs, Colorado 


\section{Conversion Factors}

U.S. customary units to International System of Units

\begin{tabular}{lcl}
\hline \multicolumn{1}{c}{ Multiply } & \multicolumn{1}{c}{ By } & \multicolumn{1}{c}{ To obtain } \\
\hline inch (in.) & Length & \\
inch (in.) & 2.54 & centimeter $(\mathrm{cm})$ \\
foot (ft) & 25.4 & millimeter $(\mathrm{mm})$ \\
mile (mi) & 0.3048 & meter $(\mathrm{m})$ \\
\hline & 1.609 & kilometer $(\mathrm{km})$ \\
\hline square mile $\left(\mathrm{mi}^{2}\right)$ & Area & hectare $(\mathrm{ha})$ \\
square mile $\left(\mathrm{mi}^{2}\right)$ & 259.0 & square kilometer $\left(\mathrm{km}^{2}\right)$ \\
\hline & 2.590 & \\
\hline cubic foot $\left(\mathrm{ft}^{3}\right)$ & Volume & cubic decimeter $\left(\mathrm{dm}^{3}\right)$ \\
cubic foot $\left(\mathrm{ft}^{3}\right)$ & 28.32 & cubic meter $\left(\mathrm{m}^{3}\right)$ \\
\hline & 0.02832 & \\
\hline foot per second $(\mathrm{ft} / \mathrm{s})$ & Velocity & meter per second $(\mathrm{m} / \mathrm{s})$ \\
\hline cubic foot per second $\left(\mathrm{ft}^{3} / \mathrm{s}\right)$ & 0.3048 & cubic meter per second $\left(\mathrm{m}^{3} / \mathrm{s}\right)$ \\
\hline
\end{tabular}

Vertical coordinate information is referenced to the North American Vertical Datum of 1988 (NAVD 88).

Horizontal coordinate information is referenced to the North American Datum of 1983 (NAD 83).

Elevation, as used in this report, refers to distance above the vertical datum.

Water year in this report is defined as the 12-month period from October 1 through September 30 and is designated by the year in which it ends.

\section{Abbreviations}

$\begin{array}{ll}\text { CDOT } & \text { Colorado Department of Transportation } \\ \text { GIS } & \text { geographic information system } \\ \text { GNSS } & \text { Global Navigation Satellite Systems } \\ \mathrm{n} & \text { Manning roughness coefficient } \\ \text { NAD83 } & \text { North American Datum of 1983 } \\ \text { NAVD88 } & \text { North American Vertical Datum of } 1988 \\ \text { NOAA } & \text { National Oceanic and Atmospheric Administration } \\ \text { RC } & \text { reach contraction coefficient } \\ \text { RX } & \text { reach expansion coefficient } \\ \text { RTK } & \text { real-time kinematic } \\ \text { SACGUI } & \text { Slope-Area Computation Graphical User Interface } \\ \text { USGS } & \text { U.S. Geological Survey } \\ \text { UTM } & \text { Universal Transverse Mercator }\end{array}$





\title{
Peak Discharge, Flood Frequency, and Peak Stage of Floods on Big Cottonwood Creek at U.S. Highway 50 Near Coaldale, Colorado, and on Fountain Creek below U.S. Highway 24 in Colorado Springs, Colorado, 2016
}

\author{
By Michael S. Kohn, ${ }^{1}$ Michael R. Stevens, ${ }^{1}$ Amanullah Mommandi, ${ }^{2}$ and Aziz R. Khan ${ }^{2}$
}

\section{Abstract}

The U.S. Geological Survey (USGS), in cooperation with the Colorado Department of Transportation, determined the peak discharge, annual exceedance probability (flood frequency), and peak stage of two floods that took place on Big Cottonwood Creek at U.S. Highway 50 near Coaldale, Colorado (hereafter referred to as "Big Cottonwood Creek site"), on August 23, 2016, and on Fountain Creek below U.S. Highway 24 in Colorado Springs, Colorado (hereafter referred to as "Fountain Creek site"), on August 29, 2016. A one-dimensional hydraulic model was used to estimate the peak discharge. To define the flood frequency of each flood, peak-streamflow regional-regression equations or statistical analyses of USGS streamgage records were used to estimate annual exceedance probability of the peak discharge. A survey of the high-water mark profile was used to determine the peak stage, and the limitations and accuracy of each component also are presented in this report. Collection and computation of flood data, such as peak discharge, annual exceedance probability, and peak stage at structures critical to Colorado's infrastructure are an important addition to the flood data collected annually by the USGS.

The peak discharge of the August 23, 2016, flood at the Big Cottonwood Creek site was 917 cubic feet per second $\left(\mathrm{ft}^{3} / \mathrm{s}\right)$ with a measurement quality of poor (uncertainty plus or minus 25 percent or greater). The peak discharge of the August 29, 2016, flood at the Fountain Creek site was 5,970 $\mathrm{ft}^{3} / \mathrm{s}$ with a measurement quality of poor (uncertainty plus or minus 25 percent or greater).

The August 23, 2016, flood at the Big Cottonwood Creek site had an annual exceedance probability of less than 0.01 (return period greater than the 100-year flood) and had an annual exceedance probability of greater than 0.005 (return

${ }^{1}$ U.S. Geological Survey

${ }^{2}$ State of Colorado Department of Transportation period less than the 200-year flood). The August 23, 2016, flood event was caused by a precipitation event having an annual exceedance probability of 1.0 (return period of 1 year, or the 1-year storm), which is a statistically common (high probability) storm. The Big Cottonwood Creek site is downstream from the Hayden Pass Fire burn area, which dramatically altered the hydrology of the watershed and caused this statistically rare (low probability) flood from a statistically common (high probability) storm. The peak flood stage at the cross section closest to the U.S. Highway 50 culvert was 6,438.32 feet (ft) above the North American Datum of 1988 (NAVD 88).

The August 29, 2016, flood at the Fountain Creek site had an estimated annual exceedance probability of 0.5505 (return period equal to the 1.8-year flood). The August 29, 2016, flood event was caused by a precipitation event having an annual exceedance probability of 1.0 (return period of 1 year, or the 1 -year storm). The peak stage during this flood at the cross section closest to the U.S. Highway 24 bridge was $5,832.89 \mathrm{ft}$ (NAVD 88).

Slope-area indirect discharge measurements were carried out at the Big Cottonwood Creek and Fountain Creek sites to estimate peak discharge of the August 23, 2016, flood and August 29, 2016, flood, respectively. The USGS computer program Slope-Area Computation Graphical User Interface was used to compute the peak discharge by adding the surveyed cross sections with Manning roughness coefficient assignments to the high-water marks. The Manning roughness coefficients for each cross section were estimated in the field using the Cowan method.

\section{Introduction}

The U.S. Geological Survey (USGS), in cooperation with the Colorado Department of Transportation (CDOT), determined the peak discharge, annual exceedance probability (flood frequency), and peak stage of two floods that took place on Big Cottonwood Creek at U.S. 
Highway 50 near Coaldale, Colorado (hereafter referred to as the "Big Cottonwood Creek site"), on August 23, 2016, and on Fountain Creek below U.S. Highway 24 in Colorado Springs, Colorado (hereafter referred to as the "Fountain Creek site"), on August 29, 2016. Reliable peak-discharge information is critical for the proper design of streamrelated infrastructure, such as bridges and dams, and for generating flood-plain inundation maps (Kohn and others, 2016). Collection and computation of flood data, such as peak discharge, annual exceedance probability, and peak stage at structures critical to Colorado's infrastructure are an important addition to the streamflow data collected annually by the USGS.

Floods in Colorado often take place at CDOT hydraulic structures (such as bridges or culverts) where no streamgage is operating. Currently (2017), CDOT does not have the resources to document floods at hydraulic structures for which the department is responsible (Al Gross, CDOT State Senior Hydraulics Engineer, written commun., October 17, 2014). As a result, when a bridge is to be replaced, peak discharges and stages of major floods that took place at the location of the hydraulic structure often are not available for inclusion in the flood-frequency analysis and design for the new bridge. Floods in Colorado generally are only documented by the USGS if they took place at an active USGS or Colorado Division of Water Resources streamgage (Kimbrough and Holmes, 2015). Thus, some of the most extreme floods that take place remain undocumented, with little information available about their location, magnitude, or frequency. Beyond their use in the design of hydraulic structures, additional flood data can be used to verify or refine the regional envelope curves (graph plotting the largest documented flood in a region as a function of drainage area) for floods in Colorado and characterize flood hydrology at miscellaneous sites where the USGS has historically collected streamflow data.

\section{Purpose and Scope}

The purpose of this report is to estimate the peak discharge, flood frequency, and peak stage of two floods that took place in 2016 at CDOT hydraulic structures in Colorado. Quantification of the flood magnitude will improve the understanding of the hydrology at these hydraulic structures and will help to ensure they are properly designed. The two sites were chosen collaboratively with CDOT staff based on the magnitude of each flood, availability of flood evidence, and location of the sites in relation to a wildfire or urban area. A one-dimensional hydraulic model was used to estimate the peak discharge. To define the flood frequency of each flood, peak-streamflow regional-regression equations or statistical analyses of USGS streamgage records were used to estimate annual exceedance probability of the peak discharge. A survey of the high-water mark profile was used to determine the peak stage, and the limitations and accuracy of each component also are presented in this report.

\section{Methods}

Standard USGS techniques and methods for indirect discharge measurements and flood-frequency analysis were followed as described in Benson and Dalrymple (1967), Dalrymple and Benson (1968), and Interagency Advisory Committee on Water Data $(1982 ; 2014)$.

\section{High-Water Mark and Cross Section Surveys}

High-water marks are postflood evidence that mark the highest elevation and water-surface slope of floodwaters (Koenig and others, 2016). High-water marks were identified and documented following the techniques and methods in Koenig and others (2016). All high-water marks and cross sections were surveyed following the techniques and methods in Rydlund and Densmore (2012). High-water marks are used to identify the peak water-surface elevation at each cross section and water-surface slope through the study reach, which are two of the main components used to estimate peak discharge.

The survey was carried out using a real-time kinematic (RTK) Global Navigation Satellite Systems (GNSS) survey. All survey data are referenced to Universal Transverse Mercator (UTM) Zone 13 north projection; the North American Datum of 1983 (NAD83); and the North American Vertical Datum 1988 (NAVD88), GEOID2012B model. Throughout this report, locations and elevations will be presented relative to these datums and projection.

The Big Cottonwood Creek site was surveyed using a Trimble R8 GNSS base unit receiver (serial number: 4638122276) equipped with a Trimble TDL450H radio (serial number: 12489653), and a rover unit that consisted of a Trimble R8 GNSS receiver (serial number: 5242498441) and a Trimble TSC3 data controller (serial number: RS1GC29459) mounted on a 6.562-foot survey rod. The Fountain Creek site was surveyed using aTrimble R8 GNSS base unit receiver (serial number: 4638122276) equipped with a Trimble TDL450H radio (serial number: 12489653) and two rover units that each consisted of a Trimble R8 GNSS receiver (serial number: 5242498441 and 4638122169 ) and a Trimble TSC2 or a TSC3 data controller (serial number: RS1GC29459 and SS28A20026) mounted on 6.562-foot survey rods. At the Big Cottonwood Creek site, the survey began and was completed with the instrument setup on reference mark 1, which was established September 20, 2016. The closure error was 0.083 feet (ft) for the northing, $0.117 \mathrm{ft}$ for the easting, and $0.022 \mathrm{ft}$ for the elevation. At the Fountain Creek site, the survey began and was completed with the instrument setup on reference mark 10, which was established January 5, 2010. The closure error was $0.048 \mathrm{ft}$ for the northing, $0.015 \mathrm{ft}$ for the easting, and $0.021 \mathrm{ft}$ for the elevation.

After the cross sections were surveyed, the condition (bed material, channel irregularity, variation, obstructions, and vegetation) of each cross section was documented and the Manning roughness coefficients for each cross section were estimated in the field using the Cowan method (Cowan, 1956). 


\section{Computation of Peak Discharge}

The peak-discharge computation was carried out following the guidelines identified in Benson and Dalrymple (1967) and Dalrymple and Benson (1968). The slope-area indirect discharge method uses high-water marks, three or more cross sections, and Manning roughness coefficients at each cross section to estimate peak discharge of a stream. Dalrymple and Benson (1968) present the application of the slope-area indirect discharge method and provide examples of its use. The USGS computer program Slope-Area Computation Graphical User Interface (SACGUI) (Fulford, 1994; Bradley, 2012) was used to compute the peak discharge by adding the surveyed cross sections with Manning roughness coefficient assignments to the high-water marks that were previously plotted by SACGUI in the field. The slope-area method computes discharge on the basis of a uniform-flow equation involving channel characteristics, water-surface profiles, and a roughness or retardation coefficient (Dalrymple and Benson, 1968). The slope-area method is based on one-dimensional, gradually varied, steady-flow equations and uses the conservation of energy and mass and the normal-flow equation to estimate discharge (Fulford, 1994).

\section{Flood-Frequency Analysis of Peak Discharge}

Two different methods were used to perform floodfrequency analyses based on each site's proximity to a streamgage. The Big Cottonwood Creek site was not located near any streamgages; therefore, peak-streamflow regionalregression equations were used to perform flood-frequency analyses at ungaged sites. The peak-streamflow regional-regression equations are based on statistical relations between peak-streamflow data at streamgages on a regional scale and watershed or climatic characteristics. The Fountain Creek site was located approximately $370 \mathrm{ft}$ downstream from a USGS streamgage with more than 25 years of record; therefore, the historical streamgage data were used in the flood-frequency analysis.

\section{Big Cottonwood Creek Site}

The USGS web-based computer program, StreamStats, (http://water.usgs.gov/osw/streamstats/index.html) (Ries and others, 2004; USGS, 2016c) was used to compute the flood-frequency analysis at the Big Cottonwood Creek site. StreamStats uses peak-discharge regional-regression equations published in Capesius and Stephens (2009) and Kohn and others (2016) to estimate the annual exceedance probability discharge for streams in Colorado not significantly affected by regulation, diversions, channelization, backwater, or urbanization.

\section{Fountain Creek Site}

The USGS software program, PeakFQ version 7.1 (Veilleux and others, 2014), was used to compute the flood-frequency analysis at the Fountain Creek site using statistical analysis of USGS streamgage record. Due to the site's proximity to the USGS streamgage 07105530 , the flood-frequency analysis was determined using 26 years of peak-streamflow data from USGS streamgage 07105530 from water year 1990 through 2015 (October 1, 1989, through September 30, 2015) and the flood discharge from the August 29, 2016, flood event (USGS National Water Information System, 2016b). Because a large portion of the watershed upstream from this site is urbanized, weighting the flood-frequency estimate with the regional estimate from the peak-discharge regional-regression equations was not appropriate and thus, only the at-site flood frequency analysis was estimated. Additional information on performing flood-frequency analyses with PeakFQ can be found in Veilleux and others (2014).

\section{Estimation of Peak Stage}

The SACGUI determines the water-surface elevation at every cross section in the study based on the surveyed watersurface profile. Peak stage associated with the computed discharge for each site was estimated from the water-surface elevation at the cross section nearest to the culvert or bridge located at the site.

\section{Big Cottonwood Creek at U.S. Highway 50 near Coaldale, Colorado}

Hourly precipitation data obtained from the National Weather Service (2016) provide evidence that the flood event on August 23, 2016, on the Big Cottonwood Creek site was caused by a local storm 5 hours in duration. Rainfall totals from the storm ranged from 0.31 to 1.20 inches (in.) within the Big Cottonwood Creek watershed upstream from the Big Cottonwood Creek site (National Weather Service, 2016) (fig. 1). The watershed-averaged total precipitation upstream from the Big Cottonwood Creek site for the storm was determined using a geographic information system (GIS) to be 0.76 in. (Esri, 2016). From National Oceanic and Atmospheric Administration (NOAA) Atlas 14 (Perica and others, 2013), the watershed-averaged 6-hour, 1-year precipitation for Big Cottonwood Creek above the Big Cottonwood Creek site is 1.08 in. Because NOAA Atlas 14 (Perica and others, 2013) does not publish precipitation estimates for 5-hour storm events, the 5-hour storm from August 23, 2016, was compared to the 6-hour storm in NOAA Atlas 14 (Perica and others, 2013). As a result, the August 23, 2016, flood event was caused by a precipitation event having an annual exceedance probability of 1.0 (return period of 1 year, or the "1-year storm"), which is a statistically common (high probability) storm. 
Floods on Big Cottonwood Creek, Coaldale, and Fountain Creek, Colorado Springs, Colo.

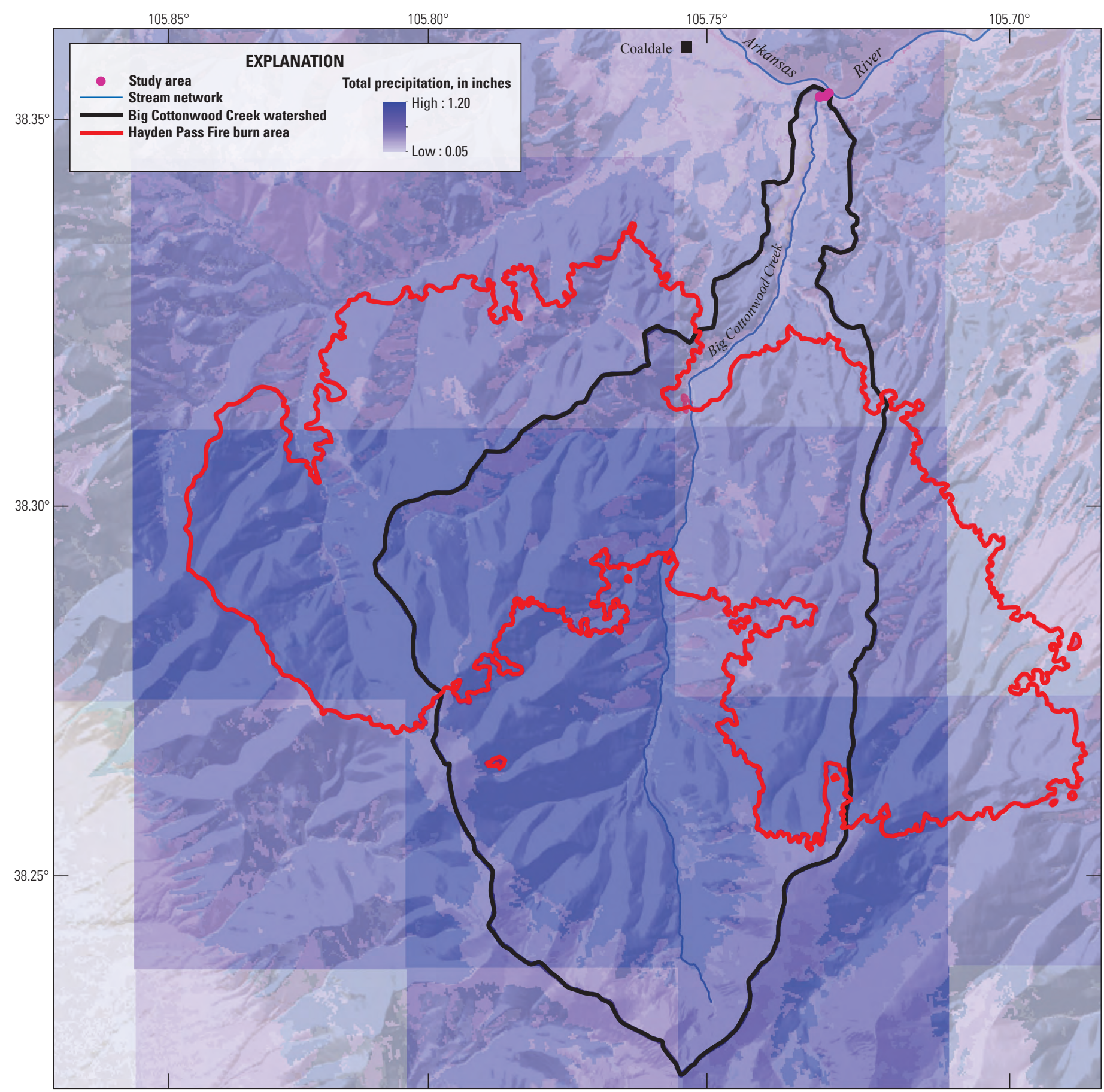

Base map modified from Esri ArcGIS Online, 2016

Universal Transverse Mercator, Zone 13 North, North American Datum of 1983
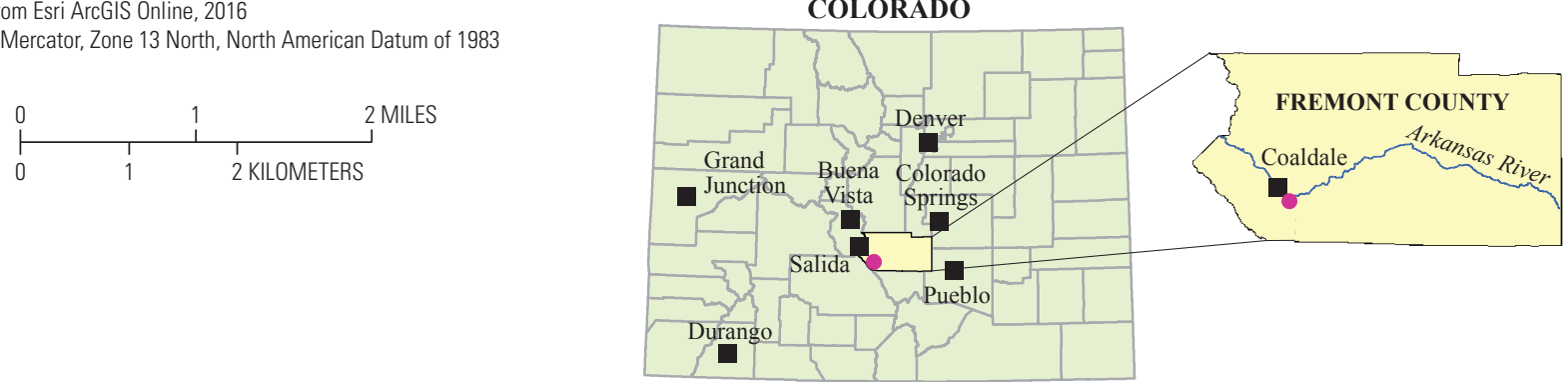

Figure 1. Location of the Big Cottonwood Creek watershed and August 23, 2016, storm near Coaldale, Colorado. 


\section{Description of the Study Area}

The Big Cottonwood Creek watershed is 24.5 square miles $\left(\mathrm{mi}^{2}\right)$ (USGS, 2016c) and drains into the Arkansas River near the town of Coaldale, Colorado (fig. 1). Big Cottonwood Creek is a high gradient, mountain stream consisting mostly of cobble and boulder in the channel with the mouth at an elevation of approximately 6,430 ft (USGS, 2016c). The mouth of Big Cottonwood Creek is approximately $100 \mathrm{ft}$ from the upstream side of the U.S. Highway 50 culvert (fig. 2) (Esri, 2016). The Big Cottonwood Creek site is downstream from the burn area caused by the 2016 Hayden Pass Fire (fig. 1), which has dramatically altered the hydrology of the watershed (USGS, 2016a).
The Big Cottonwood Creek site is located near the mouth of Big Cottonwood Creek about 0.9 miles (mi) eastsoutheast of Coaldale (fig. 2). The upstream extent of the site is at $38^{\circ} 21^{\prime} 31.89^{\prime \prime} \mathrm{N}$. latitude and $105^{\circ} 43^{\prime} 59.80^{\prime \prime} \mathrm{W}$. longitude, and the downstream extent of the site is at $38^{\circ} 21^{\prime} 33.41^{\prime \prime}$ N. latitude and $105^{\circ} 43^{\prime} 54.79^{\prime \prime}$ W. longitude. The reach associated with the Big Cottonwood Creek site begins $500 \mathrm{ft}$ upstream from the upstream side of the U.S. Highway 50 culvert and extends downstream to $69 \mathrm{ft}$ upstream from the upstream side of the U.S. Highway 50 culvert (Esri, 2016). The reach was chosen because of the good channel uniformity, availability of flood evidence, and proximity to the U.S. Highway 50 culvert.

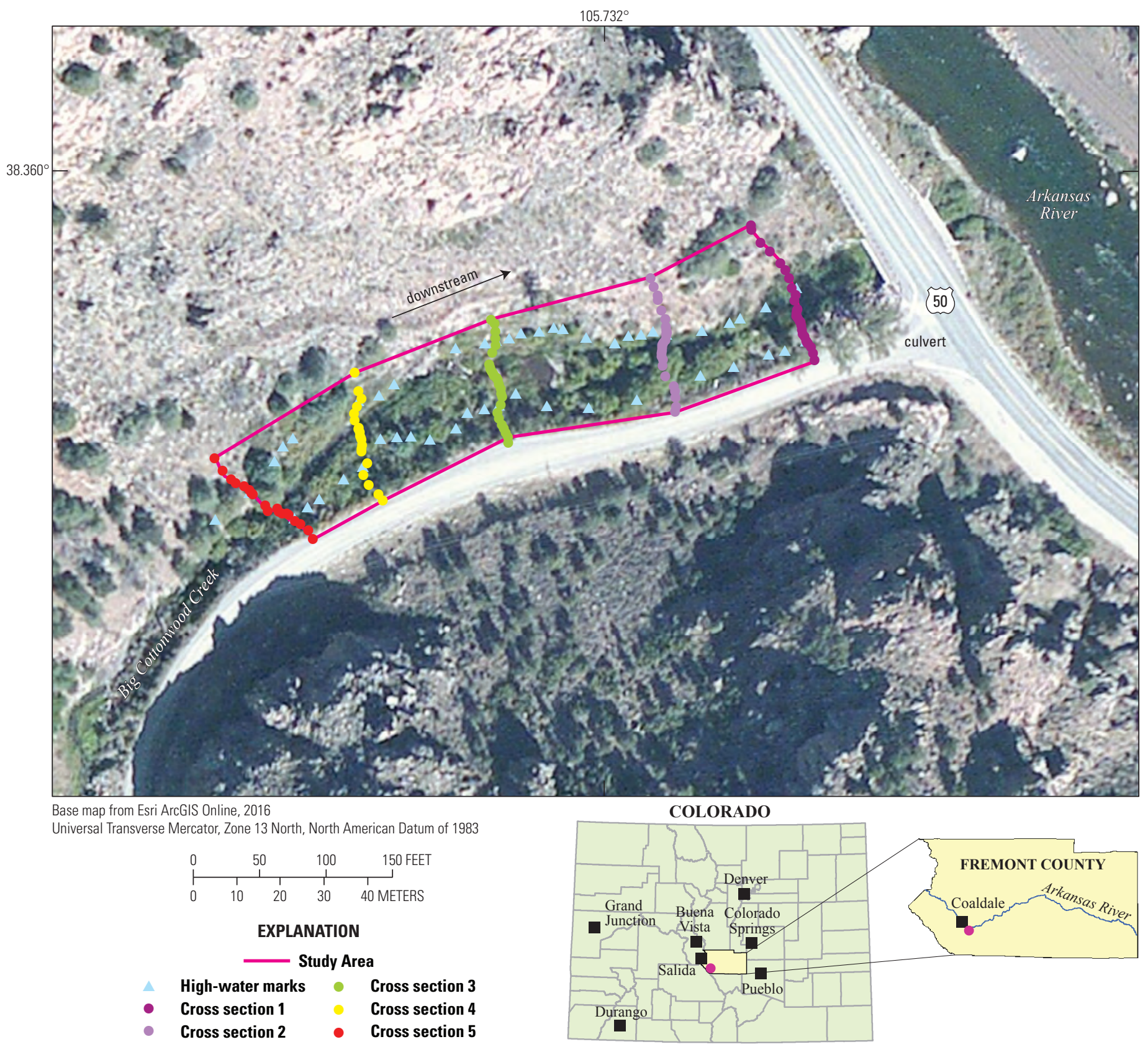

Figure 2. Location of the site at the mouth of Big Cottonwood Creek at U.S. Highway 50 near Coaldale, Colorado. 


\section{High-Water Mark and Cross Section Surveys}

The 431-ft reach where the slope-area measurement was located has a west to east orientation with a very slight right bend near the upstream end (figs. 2, 3) and a total measured fall (defined by change in elevation of the high-water mark profile through the reach) of approximately $18.5 \mathrm{ft}$. Five cross sections were surveyed as part of the slope-area measurement, with cross section 5 being the most upstream and cross section 1 the most downstream, closest to the U.S. Highway 50 culvert (figs. 2, 3). Based on the high-water mark evidence at the Big Cottonwood Creek site, effects of backwater from the culvert were contained within the wingwalls leading into the culvert and no backwater effects were present at cross section 1 .
The USGS personnel identified, flagged, and surveyed 49 high-water marks at the Big Cottonwood Creek site on September 20, 2016. All high-water marks and cross sections were surveyed on September 20, 2016, by USGS personnel. Additional information on the survey is in the field notes in appendix 1 .

A summary of the 49 high-water marks (27 on the left bank, 22 on the right bank) collected at the Big Cottonwood Creek site used to estimate the peak discharge for the August 23,2016 , flood are listed in table 1 and photographs of the high-water marks are shown in appendix 2 . The quality of the high-water marks ranged from fair to very poor due to the size of the debris that was used for the high-water marks and the time elapsed between the flood event and when the high-water marks were flagged; quality determinations followed criteria in

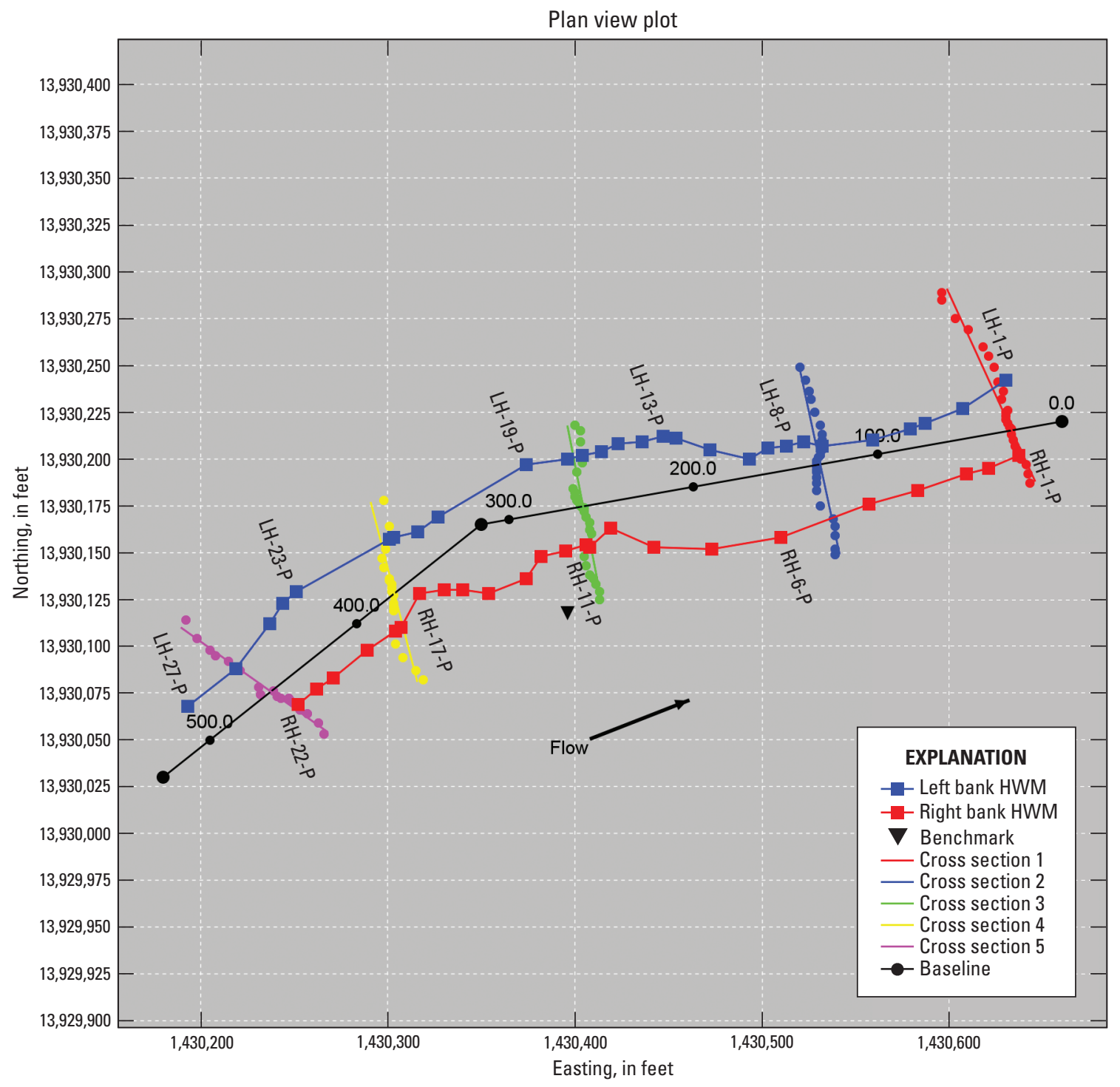

Figure 3. Plan view of the site showing the left and right bank high-water marks (HWMs) and cross sections for Big Cottonwood Creek at U.S. Highway 50 near Coaldale, Colorado; generated using the Slope-Area Computation Graphical User Interface. For readability, not all data points are labeled. 
Table 1. Summary of the 49 high-water marks collected at Big Cottonwood Creek at US Highway 50 near Coaldale, Colo. and were used to determine the peak discharge for the August 23, 2016 flood.

[ID, identification; HWM, high-water mark from Koenig and others (2016); fair, \pm 0.20 foot; poor, \pm 0.40 foot; very poor, greater than \pm 0.40 foot; NAVD88, North American Vertical Datum of 1988; LH, left high-water mark; P, poor; VP, very poor; F, fair; RH, right high-water mark]

\begin{tabular}{|c|c|c|c|c|c|c|c|c|c|}
\hline Point ID & Type & $\begin{array}{l}\text { HWM } \\
\text { rating }\end{array}$ & Bank & $\begin{array}{l}\text { Elevation, } \\
\text { in feet } \\
\text { (NAVD88) }\end{array}$ & Point ID & Type & $\begin{array}{l}\text { HWM } \\
\text { rating }\end{array}$ & Bank & $\begin{array}{l}\text { Elevation, } \\
\text { in feet } \\
\text { (NAVD88) }\end{array}$ \\
\hline LH-1-P & seed line & poor & left & $6,437.34$ & RH-1-P & debris line & poor & right & $6,439.01$ \\
\hline LH-3-P & seed line & poor & left & $6,439.59$ & RH-3-P & debris line & poor & right & $6,439.97$ \\
\hline LH-4-P & seed line & poor & left & $6,440.38$ & RH-4-P & seed line & poor & right & $6,441.03$ \\
\hline LH-7-P & seed line & poor & left & $6,444.24$ & RH-7-P & debris line & poor & right & $6,446.35$ \\
\hline LH-8-P & seed line & poor & left & $6,444.61$ & RH-8-P & seed line & poor & right & $6,446.29$ \\
\hline LH-9-P & seed line & poor & left & $6,445.34$ & RH-9-P & seed line & poor & right & $6,447.92$ \\
\hline LH-10-P & seed line & poor & left & $6,445.16$ & RH-10-P & seed line & poor & right & $6,449.45$ \\
\hline LH-11-VP & debris line & very poor & left & $6,446.46$ & RH-11-P & debris line & poor & right & $6,449.61$ \\
\hline LH-15-P & seed line & poor & left & $6,447.63$ & RH-15-P & seed line & poor & right & $6,450.77$ \\
\hline LH-16-P & seed line & poor & left & $6,447.68$ & RH-16-P & seed line & poor & right & $6,451.83$ \\
\hline LH-17-P & debris line & poor & left & $6,449.24$ & RH-17-P & seed line & poor & right & $6,452.38$ \\
\hline LH-18-P & debris line & poor & left & $6,449.60$ & RH-18-P & seed line & poor & right & $6,454.19$ \\
\hline LH-19-P & seed line & poor & left & $6,451.53$ & RH-19-P & seed line & poor & right & $6,455.28$ \\
\hline LH-20-P & seed line & poor & left & $6,451.59$ & RH-20-P & debris line & poor & right & $6,455.77$ \\
\hline LH-21-P & seed line & poor & left & $6,452.03$ & RH-21-P & wash line & poor & right & $6,456.32$ \\
\hline LH-22-P & seed line & poor & left & $6,452.38$ & RH-22-P & debris line & poor & right & $6,456.78$ \\
\hline LH-23-P & seed line & poor & left & $6,454.89$ & & & & & \\
\hline LH-24-P & seed line & poor & left & $6,455.53$ & & & & & \\
\hline LH-25-P & debris line & poor & left & $6,455.68$ & & & & & \\
\hline
\end{tabular}

table 2 of Koenig and others (2016). The SACGUI was used to establish a longitudinal baseline (for downstream stationing) on the plan-view plot of the Big Cottonwood Creek site (fig. 3). High-water marks were plotted (fig. 4) in the field on September 20,2016, to determine the optimal cross section locations, as recommended in Benson and Dalrymple (1967) (fig. 4).

Channel roughness was characterized by the Manning roughness coefficient (Chow, 1959). The USGS personnel documented the condition of each cross section and estimated the Manning roughness coefficients in the field for each cross section based on the Cowan method at the Big Cottonwood Creek site, which are listed in table 2.

The channel reach at the Big Cottonwood Creek site was generally straight, with a minor right bend at the upstream end of the reach. The streambed material throughout the reach consisted primarily of cobbles and boulders. Minor to moderate bank scalloping and irregularity were present throughout the reach because of the occasional presence of bank sloughing and bank erosion. There were minor obstructions in the channel caused by boulders and small amounts of debris piles in the channel. There were also a number of willows and small trees adjacent to the channel, which is common in riparian ecosystems; in general, vegetation along the right bank was denser than along the left bank. Photographs of the cross section are shown in appendix 3. Additional information on the Manning roughness coefficients and channel condition is in the field notes in appendix 4 and plots of each of the cross sections including Manning roughness assignments from SACGUI are shown in appendix 5.

\section{Peak Discharge}

A slope-area indirect discharge measurement of five cross sections was carried out at the Big Cottonwood Creek site to estimate peak discharge of the August 23, 2016, flood. 


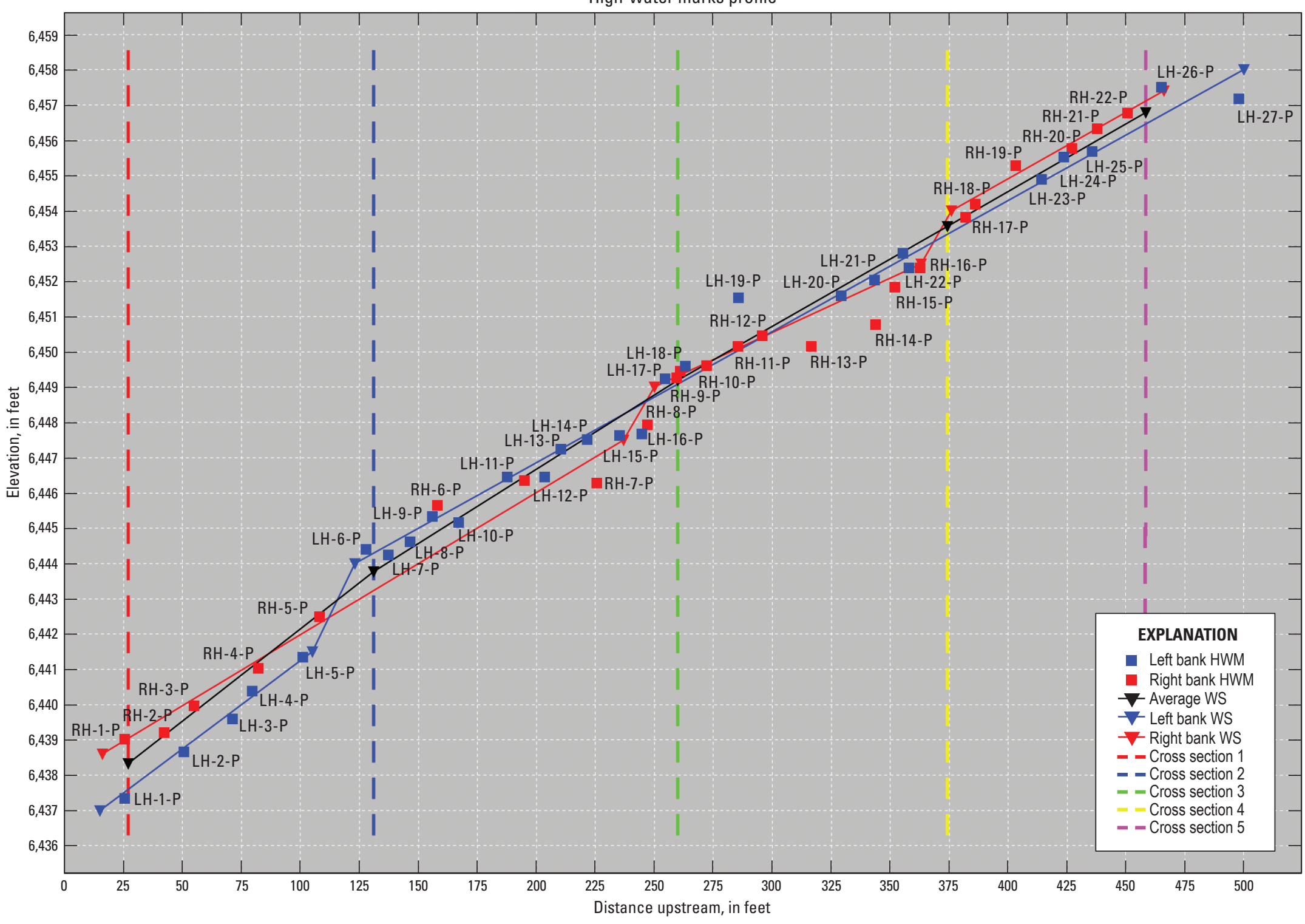

Figure 4. Profile view of the left and right bank high-water marks (HWMs) and cross sections for Big Cottonwood Creek at U.S. Highway 50 near Coaldale, Colorado; generated using the Slope-Area Computation Graphical User Interface. For readability, not all data points are labeled. [WS, water surface] 
Table 2. The Manning roughness coefficient and cross section condition for all cross sections on Big Cottonwood Creek at U.S. Highway 50 near Coaldale, Colorado.

[n, Manning roughness coefficient]

\begin{tabular}{ccl}
\hline $\begin{array}{c}\text { Cross } \\
\text { section }\end{array}$ & n & \multicolumn{1}{c}{ Condition } \\
\hline 1 & 0.083 & Cobble and boulder channel with bent over willows along banks. \\
2 & 0.079 & Cobble, boulder, and firm soil channel with grasses and willows with minor debris obstructions along banks. \\
3 & 0.084 & Cobble and boulder channel with small grasses with minor debris obstructions along banks. \\
4 & 0.084 & Sand and boulder channel with grasses and willows with minor debris obstructions along banks. \\
5 & 0.088 & Boulder channel with minimal grasses but a couple large juniper trees along banks. \\
\hline
\end{tabular}

\section{Hydraulic Modeling Results of Peak Discharge}

The high-water mark profiles used in the analysis included all 49 high-water marks and 5 cross sections that were surveyed. Water-surface elevations for each cross section were estimated by fitting a multisegmented best-fit line to all of the high-water marks throughout the reach for the left and right banks. The average water-surface elevation (determined from the left and right profiles at the location of each cross section) was used to estimate the final water-surface elevation for each cross section (fig. 4). Manning roughness coefficients in table 2 were assigned to each cross section.

During the flood, fall in the water-surface profile was approximately $18.5 \mathrm{ft}$ over a reach length of $431 \mathrm{ft}$; both characteristics were adequate because they met recommended criteria for fall (at least $0.5 \mathrm{ft}$ ) and reach length (at least 75 times the mean depth) (Dalrymple and Benson, 1968). The peak discharge of the August 23, 2016, flood at the Big Cottonwood Creek site was 917 cubic feet per second $\left(\mathrm{ft}^{3} / \mathrm{s}\right)$. The SACGUI output summary for the Big Cottonwood Creek site is in figure 5 .

\section{Evaluation and Uncertainty Analysis of Peak Discharge}

After the peak discharge is computed, a number of factors are considered to evaluate the uncertainty of the discharge measurement. Benson and Dalrymple (1967) establish an accuracy rating for the indirect discharge computations, which range from poor to good. The following factors affect the measurement quality: high-water mark quality, quality of the high-water mark profiles, water-surface fall in the reach, channel roughness uncertainty, cross section uniformity, hydraulic expansion, flow regime, and range of subreach discharges. Benson and Dalrymple (1967) and Dalrymple and Benson (1968) provide additional information on indirect discharge measurement evaluation.

Computed 2-section subreach discharges (fig. 5), using three significant figures, ranged from 719 to about $1,330 \mathrm{ft}^{3} / \mathrm{s}$ ( -21.6 to +45.0 percent compared to the accepted 5-section discharge). From the SACGUI output summary (fig. 5), the spread (defined as the percent difference between discharge computed with no expansion loss and discharge computed with full expansion loss, divided by the discharge computed with full expansion loss) between cross sections 1 and 5 was 1 percent, indicating that expansion losses in this reach were minimal. The reach contraction coefficient (RC) of 0.023 and the reach expansion coefficient (RX) of -0.022 throughout the reach indicate minor hydraulic contraction and expansion (nonuniformity) throughout the reach (fig. 5); however, because the values of RC and RX were close to zero, the reach nonuniformity does not contribute significant uncertainty to the peak-discharge estimate. Average velocities for all five cross sections of 6.0-7.9 feet per second (fig. 5) are reasonable for a steep mountain stream. For more information about the measurement diagnostics cited in this section, refer to Fulford (1994).

In cross sections 3 and 4, the Froude number is 0.87 and 0.85 , respectively, which could lead to some uncertainty in the measurement if the cross sections experienced supercritical flow (Froude number greater than 1), and Froude numbers greater than 0.8 and less than 1.2 are in the transition zone between subcritical and supercritical flow. Transitioning between subcritical and supercritical flow within SACGUI introduces uncertainty that cannot be quantified by the model (Fulford, 1994). Chow (1959) provides further discussion on the Froude number. Specific energy diagrams of cross sections 3 and 4 were developed to confirm all cross sections experienced subcritical flow (not shown). The specific energy diagrams confirmed subcritical flow was present at cross sections 3 and 4 because the minimum specific energy was located at $6,448.80 \mathrm{ft}$ and $6,453.41 \mathrm{ft}$, respectively, which was less than the water-surface elevations at cross section 3 $(6,449.19 \mathrm{ft})$ and cross section $4(6,453.56 \mathrm{ft})$, respectively.

Other than nonuniformity of the study reach, the largest field-related sources for uncertainty in this measurement are the high-water marks used to estimate the water-surface elevation at each of the cross sections and the Manning roughness coefficients assigned to each of the cross sections. Sensitivity analyses for the high-water marks and Manning roughness coefficients were carried out to evaluate these uncertainties. 


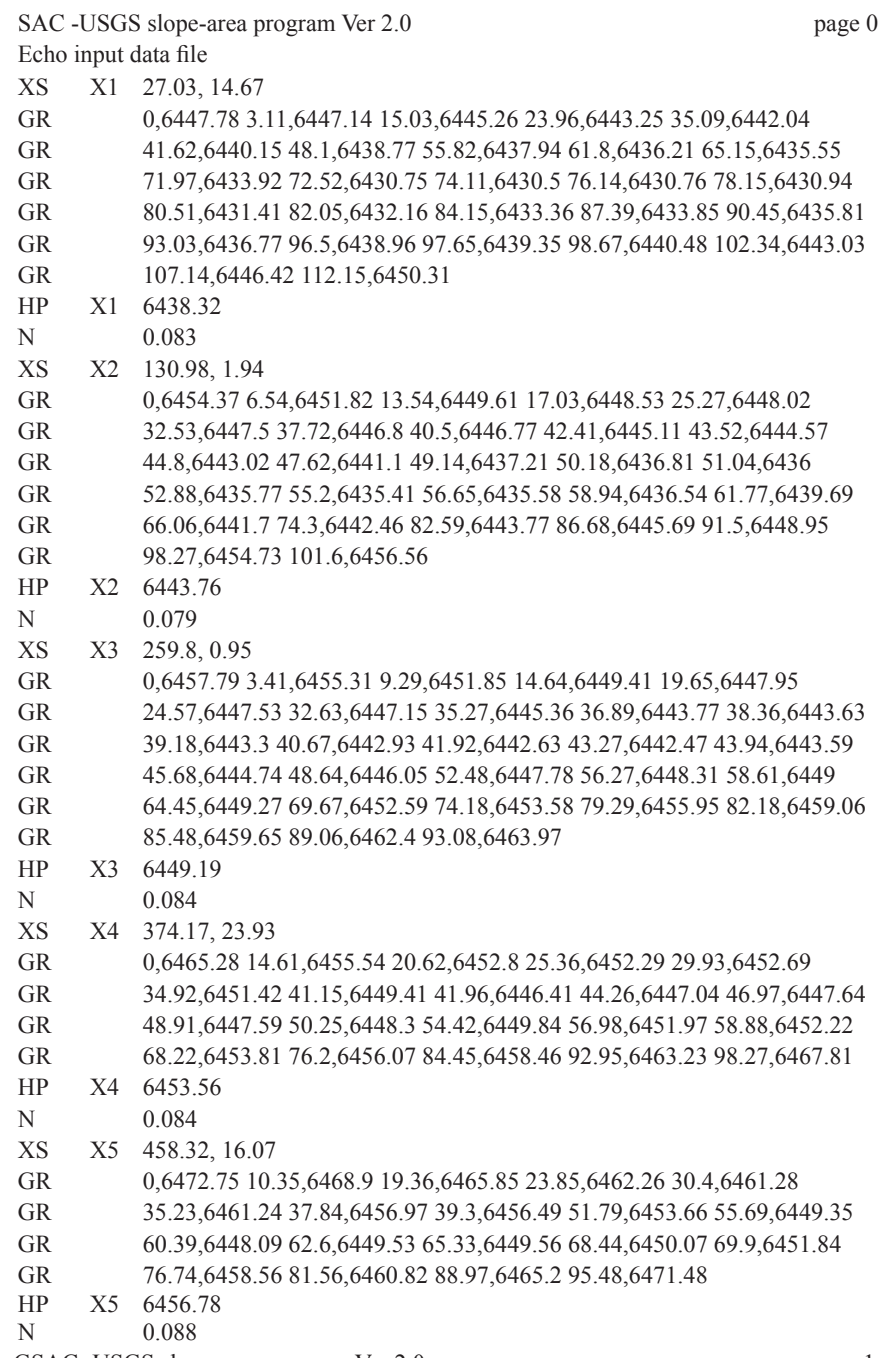

page 0

GSAC -USGS slope-area program Ver 2.0

MISCELLANEOUS Reach

dH,fall length Discharge Spread HF $\quad$ CX $\quad$ RC $\quad$ RX $\quad$ ER

\begin{tabular}{rrrrrrrrrrrr} 
& & $(\mathrm{ft})$ & $(\mathrm{ft})$ & $(\mathrm{cfs})$ & $(\%)$ & \multicolumn{1}{c}{$(\mathrm{ft})$} & & & & \\
$\mathrm{X} 5$ & $-\mathrm{X} 4$ & 3.22 & 84. & 885. & 0 & 2.836 & 1.000 & 0.135 & 0.000 & $@ \#$ \\
$\mathrm{X} 4$ & $-\mathrm{X} 3$ & 4.37 & 114. & 719. & 0 & 4.376 & 0.999 & 0.000 & -0.003 & $\#$ \\
$\mathrm{X} 3$ & $-\mathrm{X} 2$ & 5.43 & 129. & 926. & 2 & 5.556 & 0.988 & 0.000 & -0.045 & $@ \#$ \\
$\mathrm{X} 2$ & $-\mathrm{X} 1$ & 5.44 & 104. & 1333. & 2 & 5.592 & 0.986 & 0.000 & -0.055 & $\#$ \\
$\mathrm{X} 5$ & $-\mathrm{X} 3$ & 7.59 & 198. & 777. & 0 & 7.301 & 1.000 & 0.041 & -0.002 & $@ \#$ \\
$\mathrm{X} 4$ & $-\mathrm{X} 2$ & 9.80 & 243. & 814. & 1 & 9.905 & 0.995 & 0.000 & -0.021 & $@$ \\
$\mathrm{X} 3$ & $-\mathrm{X} 1$ & 10.87 & 233. & 1076. & 2 & 11.139 & 0.988 & 0.000 & -0.048 & $@$ \\
$\mathrm{X} 5$ & $-\mathrm{X} 2$ & 13.02 & 327. & 830. & 0 & 12.792 & 0.996 & 0.026 & -0.017 & \\
$\mathrm{X} 4$ & $-\mathrm{X} 1$ & 15.24 & 347. & 924. & 1 & 15.449 & 0.993 & 0.000 & -0.027 & $@$ \\
$\mathrm{X} 5$ & $-\mathrm{X} 1$ & 18.46 & 431. & 917. & 1 & 18.253 & 0.994 & 0.023 & -0.022 &
\end{tabular}

Definitions:

Spread, the percent difference between discharge computed with no expansion loss $(\mathrm{k}=0)$ and discharge computed with full expansion loss $(\mathrm{k}=1.0)$, divided by the discharge computed with full expansion loss

$\mathrm{HF}$, friction head- $\mathrm{HF}=$ sum of $\mathrm{Q}^{*} \mathrm{Q}^{*} \mathrm{~L} /(\mathrm{K} 1 * \mathrm{~K} 2)$ over subreaches; $\mathrm{Q}$, discharge; $\mathrm{L}$, reach length; $\mathrm{K} 1$, upstream section conveyance; $\mathrm{K} 2$, downstream section conveyance

$\mathrm{CX}$, the computed discharge divided by the discharge computed with no expansion loss $(\mathrm{k}=0)$

$\mathrm{RC}$, velocity head change in contracting section divided by friction head

RX, velocity head change in expanding section divided by friction head

ER, warnings, *-fall <’0.5ft, @-conveyance ratio exceeded, \#-reach too short error, 1 -negative or 0 fall

******, terms that can not be computed because' of strong expansion in reach

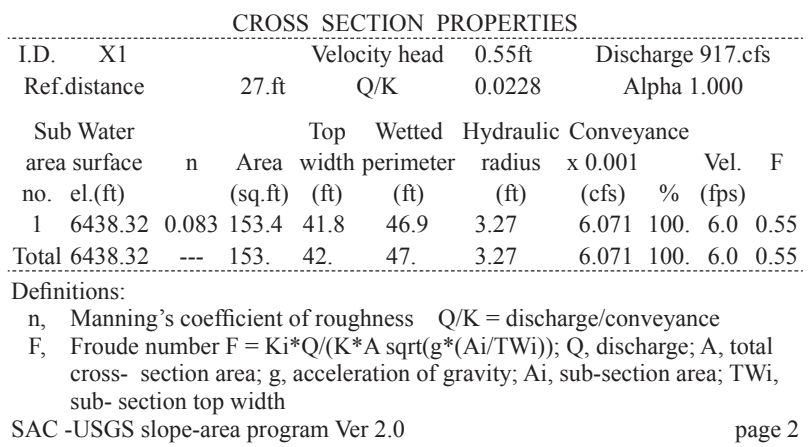

MISCELLANEOUS

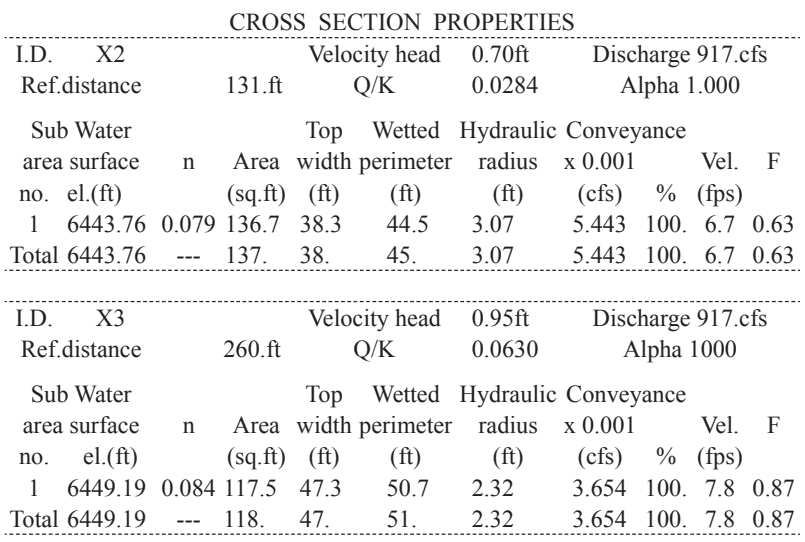

$\begin{array}{ccccc}\text { I.D. X4 } & & \text { Velocity head } & 0.97 \mathrm{ft} & \text { Discharge 917.cfs } \\ \text { Ref.distance } & \text { 374.ft } & \text { Q/K } & 0.0614 & \text { Alpha 1.000 }\end{array}$

Sub Water Top Wetted Hydraulic Conveyance

area surface $\mathrm{n} \quad$ Area width perimeter radius $\mathrm{x} 0.001 \quad$ Vel. $\mathrm{F}$ $\begin{array}{llllllll}\text { no. } & \text { el.(ft) } \quad \text { (sq.ft) } & \text { (ft) } & \text { (ft) } \quad(f t) & \text { (cfs) } & \% & \text { (fps) }\end{array}$

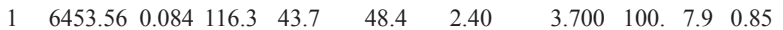
$\begin{array}{llllllllll}\text { Total } 6453.56 & -- & 116 . & 44 & 48 & 4.40 & 3.700 & 100 & 7.9 & 0.85\end{array}$

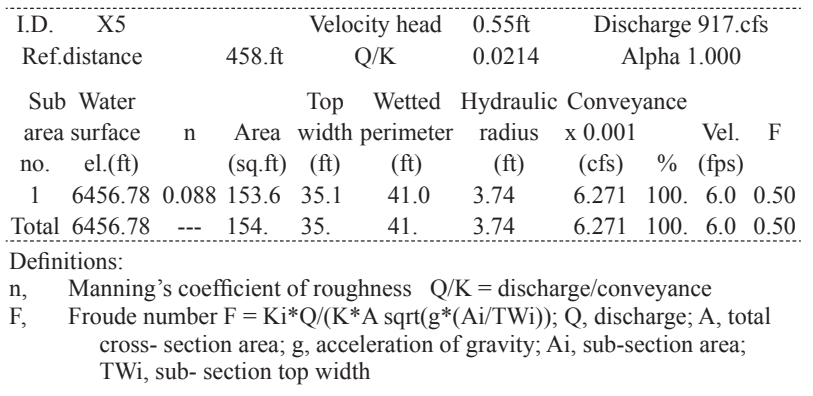

Figure 5. The Slope-Area Computation Graphical User Interface (SACGUI) model output summary for Big Cottonwood Creek at U.S. Highway 50 near Coaldale, Colorado. 
Computations assuming a range of scenarios for both main sources of uncertainty were made independently to evaluate the change in total discharge, which provides a sensitivity analysis for the measurement. Because most of the high-water marks have a quality rating of poor (table 1), the uncertainty of the high-water marks was plus or minus $( \pm) 0.40 \mathrm{ft}$ following table 2 of Koenig and others (2016). Thus, the average high-water mark profile was increased and decreased by $0.40 \mathrm{ft}$ at all cross sections, which resulted in peak discharge of $1,100 \mathrm{ft}^{3} / \mathrm{s}\left(+20.0\right.$ percent) and $771 \mathrm{ft}^{3} / \mathrm{s}(-15.9$ percent), respectively. To quantify the uncertainty in the Manning roughness coefficients, following the methods described in Kohn and others (2016) because the channel conditions and reach steepness indicated potentially large uncertainty in roughness, the Manning roughness coefficient was decreased and increased by 20 percent at all the cross sections, which resulted in a peak discharge of $1,140 \mathrm{ft}^{3} / \mathrm{s}(+24.6$ percent $)$ and $765 \mathrm{ft}^{3} / \mathrm{s}$ (-16.6 percent), respectively.

Based on the large variability in computed subreach discharges and results of the sensitivity analysis, the peak discharge of the August 23, 2016, flood at the Big Cottonwood Creek site was $917 \mathrm{ft}^{3} / \mathrm{s}$ with a measurement quality of poor (uncertainty \pm 25 percent or greater following Benson and Dalrymple [1967]).

\section{Flood-Frequency Analysis of Peak Discharge}

The annual exceedance probability discharges for the Big Cottonwood Creek site from StreamStats (USGS, 2016c) are shown in figure 6 . The 0.01 annual exceedance probability discharge (100-year flood) is $803 \mathrm{ft}^{3} / \mathrm{s}$ and 0.005 annual exceedance probability discharge (200-year flood) is $1,010 \mathrm{ft}^{3} / \mathrm{s}$. Therefore, the August 23, 2016, flood at the Big Cottonwood Creek site $\left(917 \mathrm{ft}^{3} / \mathrm{s}\right)$ had an annual exceedance probability (return period) of less than 0.01 (greater than the 100-year flood) and an annual exceedance probability (return period) of greater than 0.005 (less than the 200-year flood). The prediction error for the 0.01 and 0.005 annual exceedance probability discharge (100-year flood and 200-year flood) is 88 and 94 percent, respectively. For additional information on prediction error, see Kohn and others (2016). The peak-discharge regional-regression equations from the Foothills hydrologic region determined by StreamStats were used because the Big Cottonwood Creek site is located in the Foothills hydrologic region. Capesius and Stephens (2009) and Kohn and others (2016) developed and presented the peak-streamflow regional-regression equations in the Rio Grande hydrologic region and Foothills hydrologic region, respectively, and the corresponding prediction errors. The Big Cottonwood Creek site is downstream from the Hayden Pass Fire burn area, which dramatically altered the hydrology of the watershed (USGS, 2016a) and caused this statistically rare (low probability) flood from a statistically common (high probability) storm.

Based on the watershed drainage area of $24.5 \mathrm{mi}^{2}$, the unit discharge (defined as peak discharge divided by drainage area) for the August 23, 2016, flood at the Big Cottonwood Creek site was $37.4 \mathrm{ft}^{3} / \mathrm{s}$ per square mile. The August 23, 2016, flood at the Big Cottonwood Creek site with the envelope curve for Region 13 from Crippen and Bue (1977) is shown in figure 7. Although this flood event was rare, it still plots approximately $1 \frac{1}{2}$ orders of magnitude below the envelope curve for Region 13 established by Crippen and Bue (1977) (fig. 7).

\section{Peak Stage}

Cross section 1 was located closest to the U.S. Highway 50 culvert, so that location was used for the reference stage. Cross section 1 is located at 13,930,228.28 ft northing and $1,430,628.08 \mathrm{ft}$ easting and the peak stage from figure 5 was $6,438.32 \mathrm{ft}$.

\section{Fountain Creek below U.S. Highway 24 in Colorado Springs, Colorado}

Hourly precipitation data obtained from the National Weather Service $(2016)$ provide evidence that the flood event on August 29, 2016, on Fountain Creek below U.S. Highway 24 at Colorado Springs, Colo. (Fountain Creek site), was caused by a local storm that was 11 hours in duration (National Weather Service, 2016). Rainfall totals from the storm ranged from 0.28 to 2.55 in. within the Fountain Creek watershed upstream from the Fountain Creek site (National Weather Service, 2016) (fig. 8). The watershed-averaged precipitation for the storm upstream from the Fountain Creek site was determined to be 0.80 in. using GIS (Esri, 2016). From NOAA Atlas 14 (Perica and others, 2013), the watershed-averaged, 12-hour, 1-year precipitation for Fountain Creek above the Fountain Creek site was 1.46 in. Because NOAA Atlas 14 (Perica and others, 2013) does not publish precipitation estimates for 11-hour storm events, the 11-hour storm from August 23, 2016, was compared to the 12-hour storm in NOAA Atlas 14 (Perica and others, 2013). As a result, the storm that caused the August 29, 2016, flood event had an annual exceedance probability of 1.0 (1-year storm) in the Fountain Creek watershed above the Fountain Creek site, which is a statistically common (high probability) storm.

\section{Description of the Study Area}

The entire Fountain Creek watershed is $927 \mathrm{mi}^{2}$ (USGS, 2016c) and drains into the Arkansas River in Pueblo, Colo. (fig. 8). The Fountain Creek watershed is characterized by steep channel slopes and varied land use (Kohn and others, 2014) with elevations ranging from $4,700 \mathrm{ft}$ at the confluence with the Arkansas River to as much as $14,100 \mathrm{ft}$ at its headwaters (Stogner, 2000). These dynamics contribute to large discharges and sediment transport, which have caused periodic flooding, and sediment aggradation and deposition in Fountain Creek and its tributary streams (Kohn and others, 2014). 
Date: Fri Nov 18, 2016 10:14:51 AM GMT-7

Flow Statistics Ungaged Site Report

Study Area: Colorado

NAD 1983 Latitude: 38.3593 ( 382133 )

NAD 1983 Longitude: -105.7317 (-105 4354$)$

Drainage Area: $24.5 \mathrm{mi} 2$

\begin{tabular}{|c|c|c|c|}
\hline \multicolumn{4}{|c|}{ Peak-Flows Basin Characteristics } \\
\hline \multicolumn{4}{|c|}{ 63\% Rio Grande Region Peak Flow (Capesius and Stephens, 2009) (15.4 mi2) } \\
\hline \multirow[t]{2}{*}{ Parameter } & \multirow[t]{2}{*}{ Value } & \multicolumn{2}{|c|}{$\begin{array}{c}\text { Regression Equation Valid } \\
\text { Range }\end{array}$} \\
\hline & & Min & Max \\
\hline Drainage Area (square miles) & 24.5 & 2 & 517 \\
\hline Mean Annual Precipitation (inches) & $\begin{array}{r}17.47 \text { (below min value } \\
19) \\
\end{array}$ & 19 & 45 \\
\hline \multicolumn{4}{|c|}{ 37\% Foothills Region Peak Flow (Kohn and others, 2016) (9.14 mi2) } \\
\hline \multirow{2}{*}{ Parameter } & \multirow[t]{2}{*}{ Value } & \multicolumn{2}{|c|}{$\begin{array}{c}\text { Regression Equation Valid } \\
\text { Range } \\
\end{array}$} \\
\hline & & Min & Max \\
\hline Drainage Area (square miles) & 24.5 & 0.6 & 2,850 \\
\hline 6 Hour 100 Year Precipitation (inches) & 2.77 & 2.38 & 4.89 \\
\hline $\begin{array}{l}\text { STATSGO Percentage of Clay Soils } \\
\text { (percent) }\end{array}$ & 18.45 & 9.87 & 37.5 \\
\hline Elevation at Outlet (feet) & 6,431 & 4,290 & 8,270 \\
\hline
\end{tabular}

Warning: Some parameters are outside the suggested range. Estimates will be extrapolations with unknown errors.

\begin{tabular}{|c|c|c|c|c|c|c|}
\hline \multicolumn{7}{|c|}{ Peak-Flows Statistics Foothills Hydrologic Region (Kohn and others, 2016) } \\
\hline \multirow{2}{*}{ Statistic } & \multirow{2}{*}{ Value } & \multirow[t]{2}{*}{ Unit } & \multirow{2}{*}{$\begin{array}{l}\text { Prediction Error } \\
\text { (percent) }\end{array}$} & \multirow{2}{*}{$\begin{array}{l}\text { Equivalent years of } \\
\text { record }\end{array}$} & \multicolumn{2}{|c|}{$\begin{array}{c}\text { 90-Percent Prediction } \\
\text { Interval }\end{array}$} \\
\hline & & & & & Min & Max \\
\hline PK2 & 86.2 & $\mathrm{ft} 3 / \mathrm{s}$ & 117 & & & \\
\hline PK5 & 196 & $\mathrm{ft} 3 / \mathrm{s}$ & 87 & & & \\
\hline PK10 & 300 & $\mathrm{ft} 3 / \mathrm{s}$ & 80 & & & \\
\hline PK25 & 469 & $\mathrm{ft} 3 / \mathrm{s}$ & 80 & & & \\
\hline PK50 & 621 & $\mathrm{ft} 3 / \mathrm{s}$ & 83 & & & \\
\hline PK100 & 803 & $\mathrm{ft} 3 / \mathrm{s}$ & 88 & & & \\
\hline PK200 & 1,010 & $\mathrm{ft} 3 / \mathrm{s}$ & 94 & & & \\
\hline PK500 & 1,310 & $\mathrm{ft} 3 / \mathrm{s}$ & \begin{tabular}{|l|l|}
104 \\
\end{tabular} & & & \\
\hline
\end{tabular}

Figure 6. The StreamStats output summary for Big Cottonwood Creek at U.S. Highway 50 near Coaldale, Colorado. Image from the U.S. Geological Survey StreamStats program, accessed on Dec. 6, 2016 at https://water.usgs.gov/osw/streamstats/colorado.html. [PK100, 0.01 annual exceedance probability discharge; PK200, 0.005 annual exceedance probability discharge] 


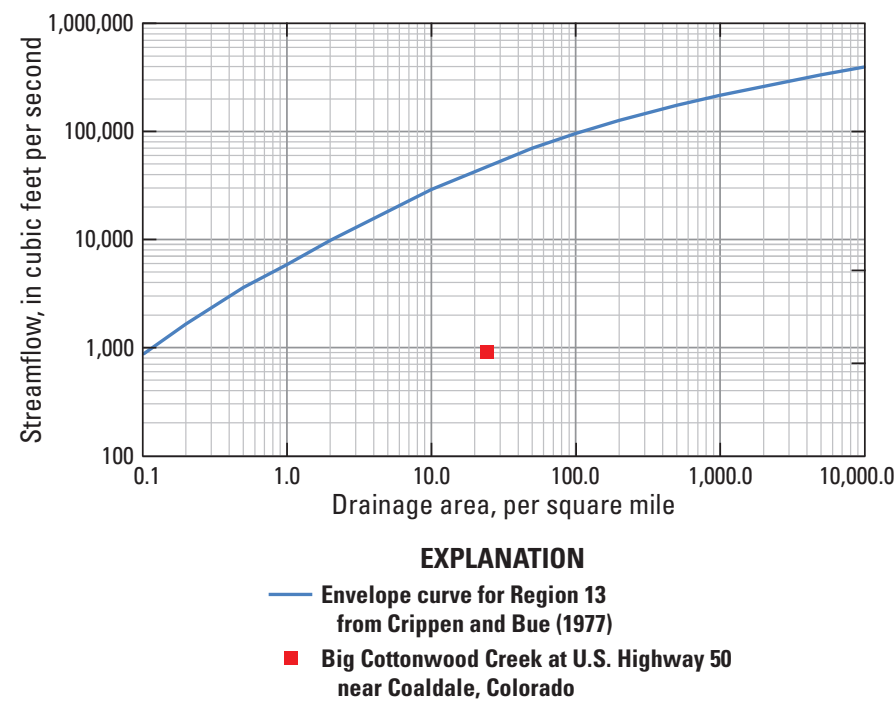

Figure 7. The envelope curve for Region 13 from Crippen and Bue (1977) with the flood of August 23, 2016, on Big Cottonwood Creek at U.S. Highway 50 near Coaldale, Colorado.

The Fountain Creek site is approximately 3,000 ft downstream from the U.S. Highway 24 bridge and approximately $370 \mathrm{ft}$ downstream from the USGS streamgage Fountain Creek below Janitell Road below Colorado Springs, Colo. (USGS streamgage 07105530) (fig. 9). The upstream extent of the site is located at $38^{\circ} 48^{\prime} 6.93^{\prime \prime} \mathrm{N}$ latitude and $104^{\circ} 47^{\prime} 37.35^{\prime \prime}$ $\mathrm{W}$ longitude, and the downstream extent of the site is located at $38^{\circ} 48^{\prime} 0.69^{\prime \prime} \mathrm{N}$ latitude and $104^{\circ} 47^{\prime} 26.61^{\prime \prime} \mathrm{W}$ longitude. The Fountain Creek site reach where the study took place begins approximately $3,000 \mathrm{ft}$ downstream from the U.S. Highway 24 bridge and extends to $4,060 \mathrm{ft}$ downstream from the U.S. Highway 24 bridge (Esri, 2016). The reach was chosen because of the good channel uniformity, availability of flood evidence, and proximity to the U.S. Highway 24 bridge. The drainage area at the U.S. Highway 24 bridge was $405 \mathrm{mi}^{2}$ compared to $412 \mathrm{mi}^{2}$ at the Fountain Creek site, a difference of 1.7 percent (USGS, 2016c). This difference is small enough that the discharge at the Fountain Creek site is assumed to be equivalent to discharge at the U.S. Highway 24 bridge and the USGS streamgage 07105530 , which also has a drainage area of $412 \mathrm{mi}^{2}$ (USGS, 2016c).

\section{High-Water Mark and Cross Section Surveys}

The 1,060-ft reach where the slope-area measurement was located has a northwest-southeast orientation with a very slight left bend near the downstream end (figs. 9, 10) and a total measured fall (defined by change in elevation of the high-water mark profile through the reach) of approximately $6.48 \mathrm{ft}$. Five cross sections were surveyed as part of the slope-area measurement, with cross section 1 being the most upstream and cross section 5 the most downstream (figs. 9, 10).
The USGS personnel identified, flagged, and documented a total of 102 high-water marks at the Fountain Creek site on August 30-31, 2016, and September 21, 2016. The USGS personnel surveyed high-water marks and cross sections on September 21, 2016. Additional information on the survey is in the field notes in appendix 6 .

A summary of the 102 high-water marks (50 on the left bank, 52 on the right bank) collected at the Fountain Creek site used to estimate the peak discharge for the August 29, 2016, flood are listed in table 3 and photographs of the high-water marks are shown in appendix 7. The quality of the high-water marks ranged from fair to poor (following criteria in table 2 of Koenig and others [2016]) due to the poor condition of the banks and minimal flood debris, which made accurate high-water mark recovery challenging. The SACGUI was used to establish a longitudinal baseline (for stationing) on the plan view plot of the Fountain Creek site (fig. 10) and high-water marks were plotted (fig. 11) in the field on September 21, 2016, to determine the optimal cross section locations per Benson and Dalrymple (1967) (fig. 9).

Channel roughness was characterized by the Manning roughness coefficient (Chow, 1959). Cross sections were subdivided on the basis of channel shape (Benson and Dalrymple, 1967) and each field-assigned roughness subdivision was evaluated in the office to check shape-ratio criteria for subdivision established by Davidian (1984). The USGS personnel documented the condition of each cross section and estimated the Manning roughness coefficients in the field for each cross section based on the Cowan method at the Fountain Creek site, which are listed in table 4.

The channel reach at the Fountain Creek site was generally straight with a gradual left bend at the downstream end of the reach. The streambed material throughout the reach consisted primarily of medium sand with scattered cobble and boulder. The left overbank had earthen bed material, consisting of firmly packed soil, and it seemed to be fairly unstable. Minor to moderate bank scalloping and irregularity was present throughout the reach, particularly along the right bank. There were only a few scattered concrete blocks and tree stumps, with no major obstructions, in the channel. There also were a number of willows and small trees adjacent to the channel, which is common in riparian ecosystems; in general, vegetation on the left overbank was denser than areas along the main channel. Photographs of the cross sections are shown in appendix 8. Additional information on the Manning roughness coefficients and channel condition are in the field notes in appendix 9. Plots of each of the cross sections including Manning roughness assignments from SACGUI are shown in appendix 10 .

\section{Peak Discharge}

A slope-area indirect discharge measurement of five cross sections was carried out at the Fountain Creek site to estimate peak discharge of the August 29, 2016, flood. 


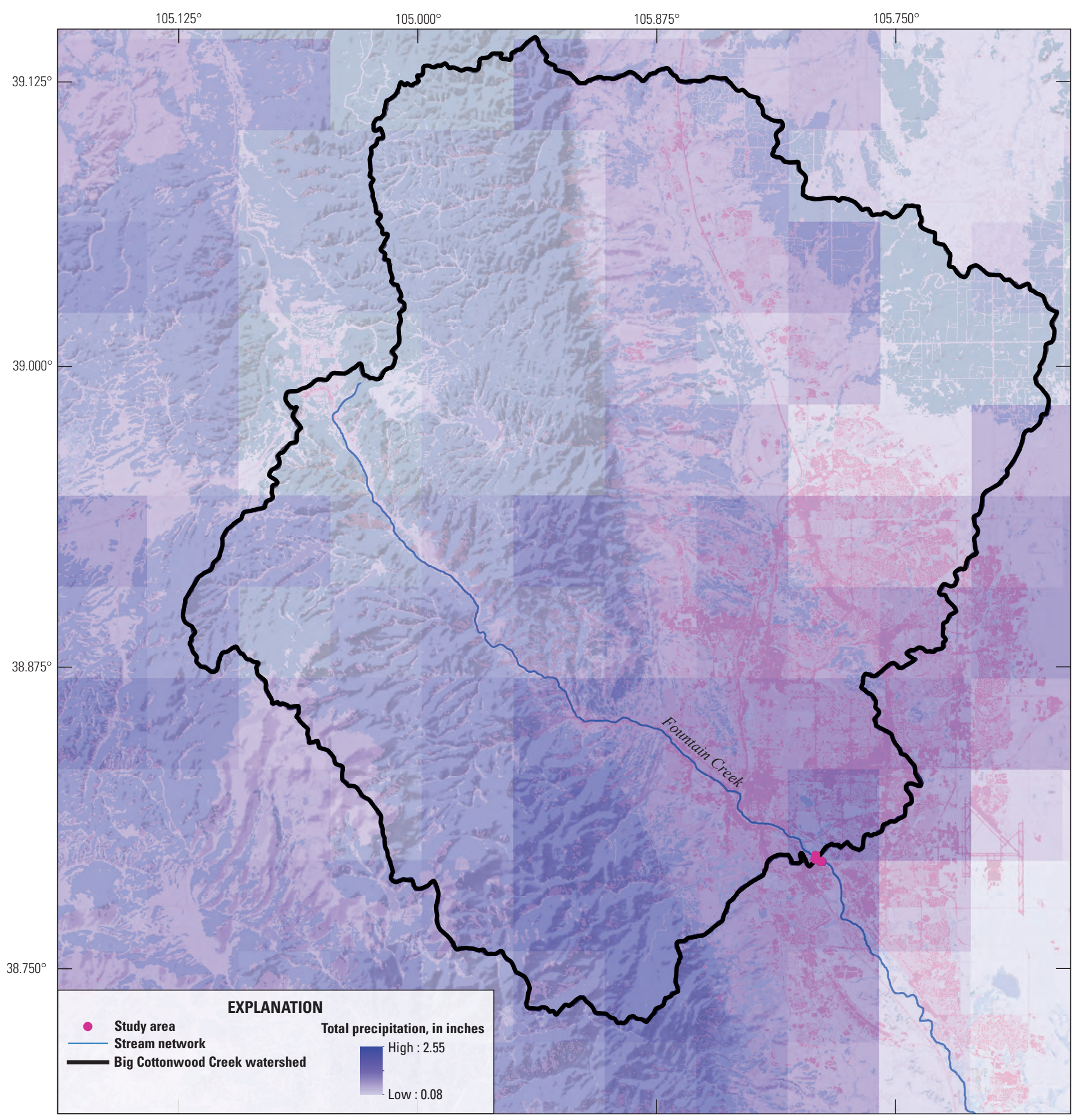

Base map modified from Esri ArcGIS Online, 2016

Universal Transverse Mercator, Zone 13 North, North American Datum of 1983

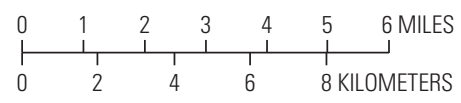

Figure 8. Location of the Fountain Creek watershed and August

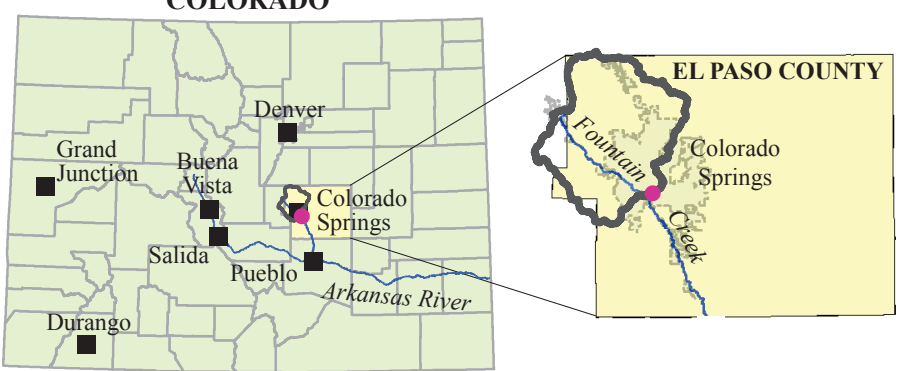
29, 2016, storm in Colorado Springs, Colorado. 


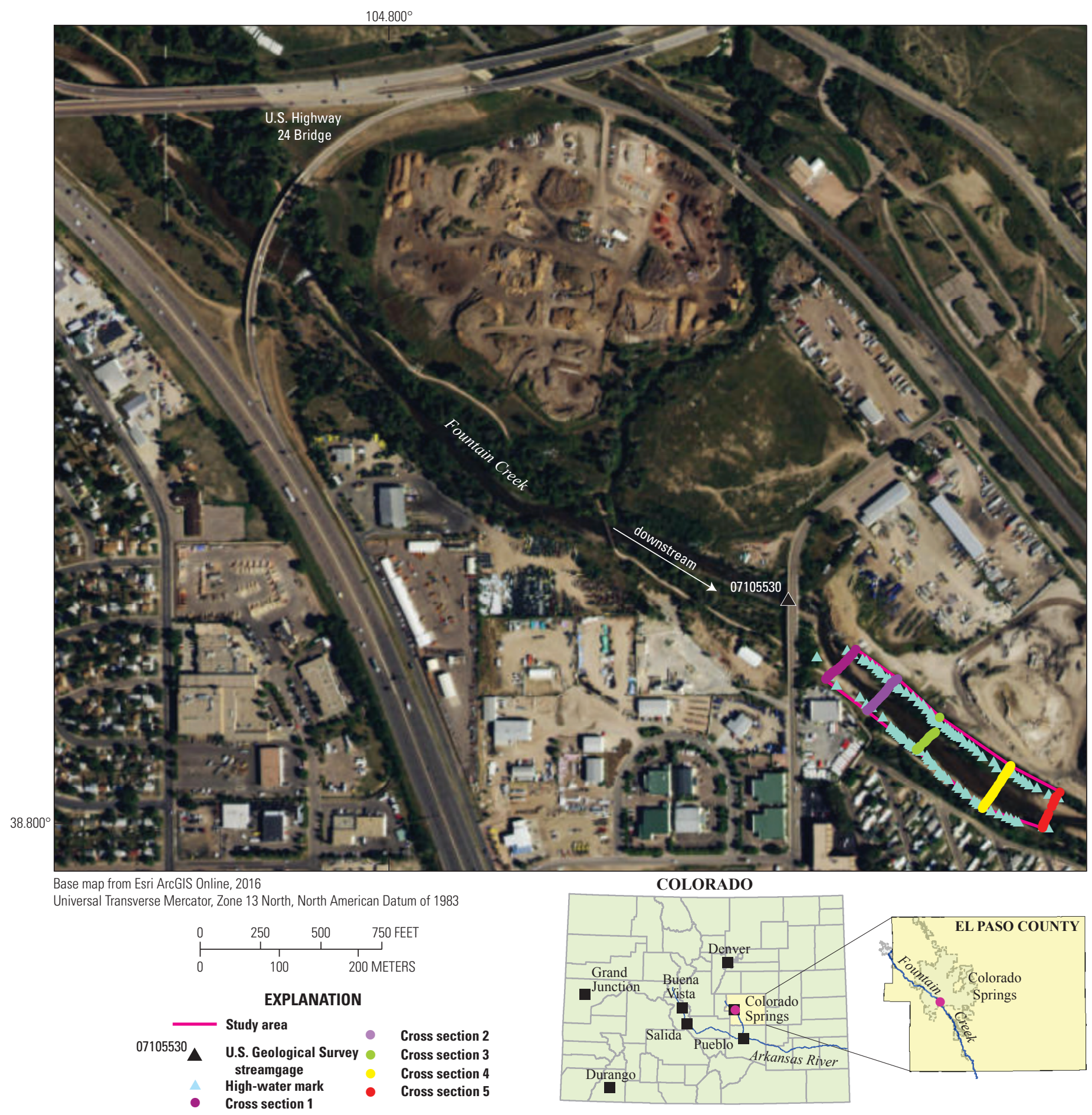

Figure 9. Location of the site for Fountain Creek below U.S. Highway 24 in Colorado Springs, Colorado. 
Table 3. Summary of the 102 high-water marks collected at Fountain Creek below US Highway 24 in Colorado Springs, Colo. and were used to determine the peak discharge for the August 29, 2016 flood.

[ID, identification; HWM, high-water mark from Koenig and others (2016); fair, \pm 0.20 foot; poor, \pm 0.40 foot; NAVD88, North American Vertical Datum of 1988; LH, left high-water mark; P, poor; F, fair; RH, right high-water mark]

\begin{tabular}{|c|c|c|c|c|c|c|c|c|c|}
\hline Point ID & Type & $\begin{array}{l}\text { HWM } \\
\text { rating }\end{array}$ & Bank & $\begin{array}{l}\text { Elevation, } \\
\text { in feet } \\
\text { (NAVD88) }\end{array}$ & Point ID & Type & $\begin{array}{l}\text { HWM } \\
\text { rating }\end{array}$ & Bank & $\begin{array}{c}\text { Elevation, } \\
\text { in feet } \\
\text { (NAVD88) }\end{array}$ \\
\hline LH-1-P & wash line & poor & left & $5,834.19$ & RH-1-P & debris line & poor & right & $5,832.05$ \\
\hline LH-3-P & debris line & poor & left & $5,830.80$ & RH-3-P & debris line & poor & right & $5,832.19$ \\
\hline LH-4-P & wash line & poor & left & $5,830.66$ & RH-4-P & debris line & poor & right & $5,830.12$ \\
\hline LH-7-P & debris line & poor & left & $5,830.87$ & RH-7-P & debris line & poor & right & $5,830.44$ \\
\hline LH-8-P & debris line & poor & left & $5,830.72$ & RH-8-P & debris line & poor & right & $5,830.36$ \\
\hline LH-9-P & debris line & poor & left & $5,830.31$ & RH-9-P & debris line & poor & right & $5,829.91$ \\
\hline LH-10-P & wash line & poor & left & $5,829.74$ & RH-10-P & wash line & poor & right & $5,829.48$ \\
\hline LH-11-P & mud line & poor & left & $5,830.02$ & RH-11-P & debris line & poor & right & $5,830.04$ \\
\hline LH-15-P & debris line & poor & left & $5,829.78$ & RH-15-P & debris line & poor & right & $5,830.03$ \\
\hline LH-16-F & debris line & fair & left & $5,830.22$ & RH-16-P & debris line & poor & right & $5,829.89$ \\
\hline LH-17-P & debris line & poor & left & $5,829.42$ & RH-17-P & debris line & poor & right & $5,829.85$ \\
\hline LH-18-P & debris line & poor & left & $5,829.37$ & RH-18-P & debris line & poor & right & $5,829.68$ \\
\hline LH-19-P & wash line & poor & left & $5,829.28$ & RH-19-P & debris line & poor & right & $5,829.23$ \\
\hline LH-20-P & wash line & poor & left & $5,829.75$ & RH-20-P & debris line & poor & right & $5,829.89$ \\
\hline LH-21-P & wash line & poor & left & $5,828.34$ & RH-21-P & debris line & poor & right & $5,830.23$ \\
\hline LH-22-P & wash line & poor & left & $5,828.14$ & RH-22-P & debris line & poor & right & $5,830.10$ \\
\hline LH-23-P & wash line & poor & left & $5,828.81$ & RH-23-P & debris line & poor & right & $5,829.50$ \\
\hline LH-24-F & wash line & fair & left & $5,829.26$ & RH-24-P & debris line & poor & right & $5,829.53$ \\
\hline LH-25-P & mud line & poor & left & $5,829.05$ & RH-25-P & debris line & poor & right & $5,829.77$ \\
\hline LH-33-F & wash line & fair & left & $5,828.74$ & RH-33-P & debris line & poor & right & $5,828.73$ \\
\hline LH-34-P & wash line & poor & left & $5,827.62$ & RH-34-P & debris line & poor & right & $5,828.56$ \\
\hline LH-35-F & debris line & fair & left & $5,827.43$ & RH-35-P & debris line & poor & right & $5,828.45$ \\
\hline LH-36-P & wash line & poor & left & $5,827.53$ & RH-36-P & debris line & poor & right & $5,827.38$ \\
\hline LH-37-F & debris line & fair & left & $5,827.60$ & RH-37-P & debris line & poor & right & $5,826.95$ \\
\hline LH-38-F & debris line & fair & left & $5,827.08$ & RH-38-P & debris line & poor & right & $5,827.30$ \\
\hline LH-39-F & debris line & fair & left & $5,827.65$ & RH-39-P & debris line & poor & right & $5,827.75$ \\
\hline LH-40-P & debris line & poor & left & $5,826.82$ & RH-41-P & debris line & poor & right & $5,828.54$ \\
\hline LH-41-F & debris line & fair & left & $5,827.46$ & RH-42-P & debris line & poor & right & $5,828.36$ \\
\hline LH-42-F & debris line & fair & left & $5,827.89$ & RH-43-P & debris line & poor & right & $5,827.77$ \\
\hline LH-43-F & debris line & fair & left & $5,827.73$ & RH-44-P & debris line & poor & right & $5,827.97$ \\
\hline LH-44-P & wash line & poor & left & $5,827.13$ & RH-45-P & debris line & poor & right & $5,827.97$ \\
\hline LH-45-F & wash line & fair & left & $5,827.33$ & RH-46-P & debris line & poor & right & $5,827.00$ \\
\hline LH-46-F & debris line & fair & left & $5,826.87$ & RH-47-P & debris line & poor & right & $5,826.66$ \\
\hline LH-47-P & wash line & poor & left & $5,827.29$ & RH-48-P & debris line & poor & right & $5,826.48$ \\
\hline
\end{tabular}


Table 3. Summary of the 102 high-water marks collected at Fountain Creek below US Highway 24 in Colorado Springs, Colo. and were used to determine the peak discharge for the August 29, 2016 flood.-Continued

[ID, identification; HWM, high-water mark from Koenig and others (2016); fair, \pm 0.20 foot; poor, \pm 0.40 foot; NAVD88, North American Vertical Datum of 1988; LH, left high-water mark; P, poor; F, fair; RH, right high-water mark]

\begin{tabular}{|c|c|c|c|c|c|c|c|c|c|}
\hline Point ID & Type & $\begin{array}{l}\text { HWM } \\
\text { rating }\end{array}$ & Bank & $\begin{array}{c}\text { Elevation, } \\
\text { in feet } \\
\text { (NAVD88) }\end{array}$ & Point ID & Type & $\begin{array}{l}\text { HWM } \\
\text { rating }\end{array}$ & Bank & $\begin{array}{c}\text { Elevation, } \\
\text { in feet } \\
\text { (NAVD88) }\end{array}$ \\
\hline LH-48-P & debris line & poor & left & $5,826.62$ & RH-49-P & debris line & poor & right & $5,825.99$ \\
\hline \multirow[t]{2}{*}{ LH-50-P } & debris line & poor & left & $5,826.61$ & RH-51-P & debris line & poor & right & $5,826.98$ \\
\hline & & & & & RH-52-P & debris line & poor & right & $5,826.48$ \\
\hline
\end{tabular}

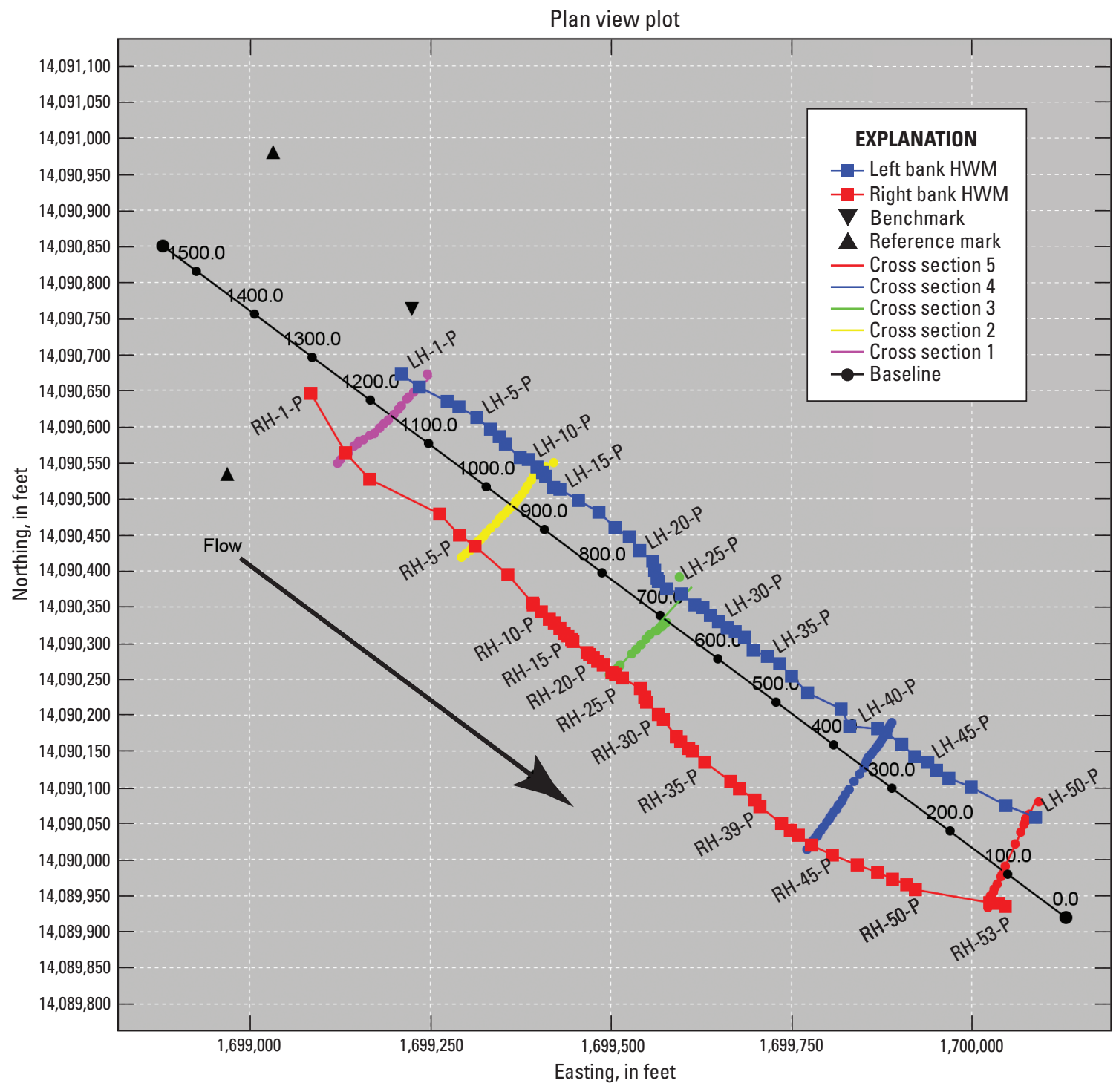

Figure 10. Plan view of the site showing the left and right bank high-water marks (HWMs) and cross sections for Fountain Creek below U.S. Highway 24 in Colorado Springs, Colorado; generated from the Slope-Area Computation Graphical User Interface. For readability, not all data points are labeled. 
Table 4. The Manning roughness coefficient and cross section conditon for all cross sections at Fountain Creek below U.S. Highway 24 in Colorado Springs, Colorado.

[n, Manning roughness coefficient]

\begin{tabular}{cccl}
$\begin{array}{c}\text { Cross } \\
\text { section }\end{array}$ & $\begin{array}{c}\text { Main channel } \\
\mathbf{n}\end{array}$ & $\begin{array}{c}\text { Left overbank } \\
\mathbf{n}\end{array}$ & \multicolumn{1}{c}{ Condition } \\
\hline 1 & 0.042 & 0.042 & Sand and gravel channel with minor shrubs at banks. \\
2 & 0.046 & 0.046 & Main channel; sand and gravel with grasses and trees along banks. \\
2 & 0.062 & 0.062 & Left overbank; grasses, willows, and small trees on sand and silt soil. \\
3 & 0.040 & 0.040 & Sand and gravel channel with shrubs and tall grass at banks. \\
4 & 0.048 & 0.048 & Main channel; sand and gravel with shrubs and trees along banks. \\
4 & 0.064 & 0.064 & Left overbank; willows and small trees on sand and silt soil. \\
5 & 0.047 & 0.047 & Sand and gravel channel with minor shrubs and small trees at banks. \\
\hline
\end{tabular}

\section{Hydraulic Modeling Results of Peak Discharge}

The high-water mark profiles used in the analysis included all 102 high-water marks and 5 cross sections that were surveyed. Because of substantial scatter among the marks, water-surface elevations for each cross section were estimated by fitting a multisegmented best-fit line to resolve the scatter in the high-water marks throughout the reach for the left and right banks. The average water-surface elevation from the left and right profiles at the location of each cross section was used to estimate the final water-surface elevation for each cross section (fig. 11). Manning roughness coefficients in table 4 were assigned to each cross section.

During the flood, fall in the water-surface profile was approximately $6.48 \mathrm{ft}$ over a reach length of $1,060 \mathrm{ft}$; both characteristics were adequate because they met the recommended criteria for fall (at least $0.5 \mathrm{ft}$ ) and reach length (at least 75 times the mean depth) (Dalrymple and Benson, 1968). The peak discharge of the August 29, 2016, flood at the Fountain Creek site was 5,970 $\mathrm{ft}^{3} / \mathrm{s}$ (using three significant figures). The SACGUI output summary for the Fountain Creek site is in figure 12.

\section{Evaluation and Uncertainty Analysis of Peak Discharge}

Computed 2-section subreach discharges (fig. 12), using three significant figures, ranged from 4,920 to $7,680 \mathrm{ft}^{3} / \mathrm{s}$ $(-17.6$ to +28.6 percent compared to the accepted 5 -section discharge). From the SACGUI output summary (fig.12), the spread (defined as the percent difference between discharge computed with no expansion loss and discharge computed with full expansion loss, divided by the discharge computed with full expansion loss) between cross sections 1 and 5 was 4 percent, indicating that expansion losses in this reach were a measurable, but relatively small, source of uncertainty in this measurement. The RC of 0.165 and the RX of -0.089 through the reach indicate minor hydraulic contraction and expansion (nonuniformity) (fig. 12); however, because the values of RC and RX were nearly zero, the minor expansion and contraction through the reach do not add significant uncertainty to the peak-discharge estimate. Average main-channel velocities for all five cross sections of 6.0-8.8 ft/s (fig. 12) are reasonable for a steep stream in an urban area with levees along both banks. All the cross sections have main channel and overbank Froude numbers of less than 0.70, which means the reach experienced subcritical flow. For more explanation about the measurement diagnostics cited in this section, see Fulford (1994).

Other than nonuniformity of the study reach, the largest sources for uncertainty in this measurement are the high-water marks used to estimate the water-surface elevation at each of the cross sections and the Manning roughness coefficients assigned to each of the cross sections. Sensitivity analyses for the high-water marks and Manning roughness coefficients were carried out to evaluate these uncertainties.

Computations assuming a range of scenarios for both main sources of uncertainty were made independently to evaluate the change in total discharge, which provides a sensitivity analysis for the measurement. Due to most of the high-water marks having a quality rating of poor (table 3), the uncertainty of the high-water marks was $\pm 0.40 \mathrm{ft}$ following table 2 of Koenig and others (2016). Thus, the average high-water mark profile was increased and decreased by $0.40 \mathrm{ft}$ at all cross sections, which resulted in peak discharge of $6,610 \mathrm{ft}^{3} / \mathrm{s}\left(+10.7\right.$ percent) and $5,360 \mathrm{ft}^{3} / \mathrm{s}(-10.2$ percent $)$, respectively. To quantify the uncertainty in the Manning roughness coefficients, following Kohn and others (2016) because the channel conditions and bank conditions indicated potentially large uncertainty in roughness, the Manning roughness coefficient was decreased and increased by 20 percent at all the cross sections, which resulted in peak discharge of $7,250 \mathrm{ft}^{3} / \mathrm{s}$ ( +21.4 percent) and $5,060 \mathrm{ft}^{3} / \mathrm{s}$ $(-15.3$ percent $)$, respectively.

Based on the results of the sensitivity analysis, the peak discharge of the August 29, 2016, flood at the Fountain Creek site was $5,970 \mathrm{ft}^{3} / \mathrm{s}$ with a measurement quality of poor (uncertainty \pm 25 percent or greater) based on the criteria established in Benson and Dalrymple (1967). 


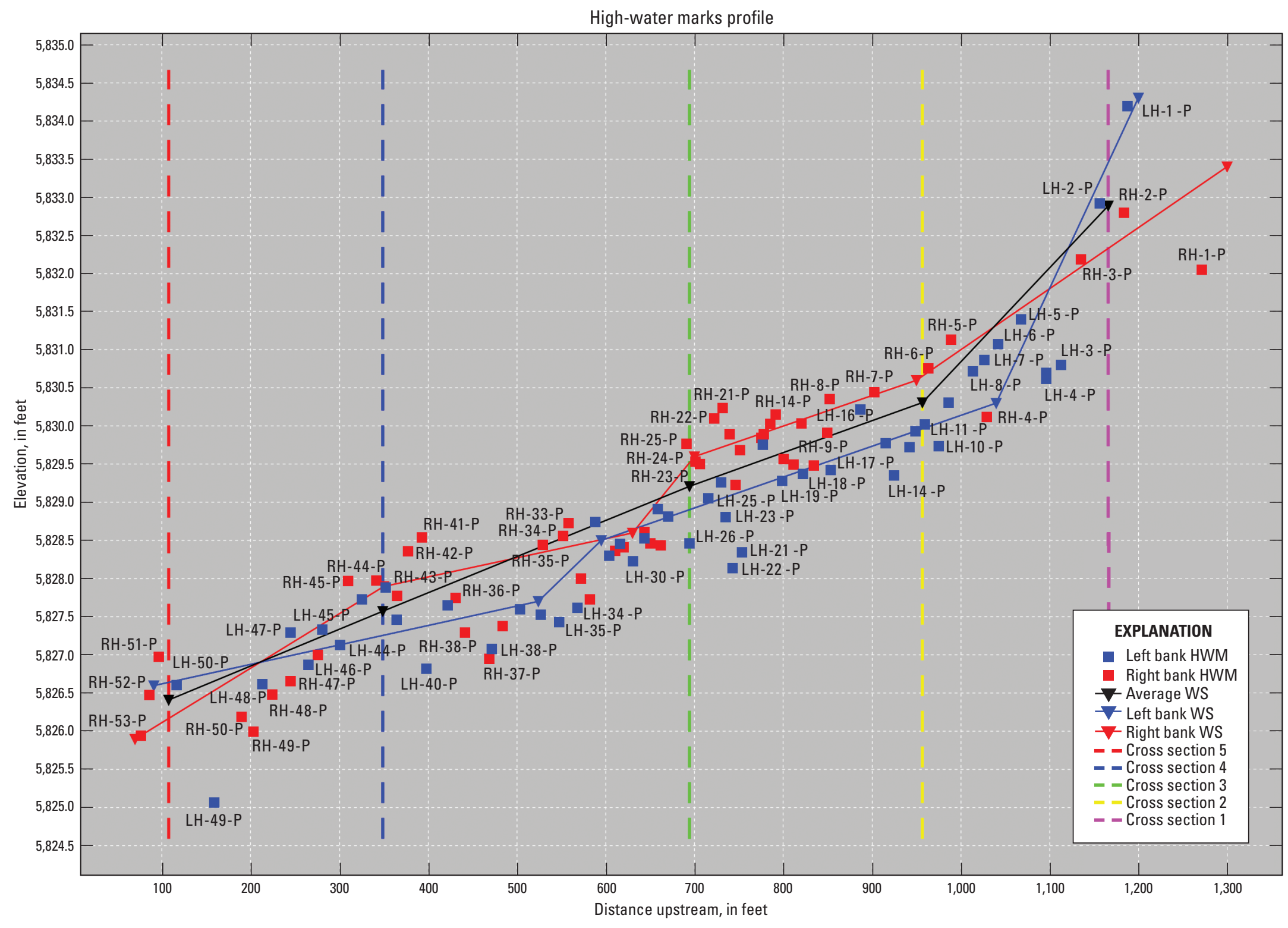

Figure 11. Profile view of the left and right bank high-water marks (HWMs) and cross sections for Fountain Creek below U.S. Highway 24 in Colorado Springs, Colorado; generated using the Slope-Area Computation Graphical User Interface. For readability, not all data points are labeled. [WS, water surface] 


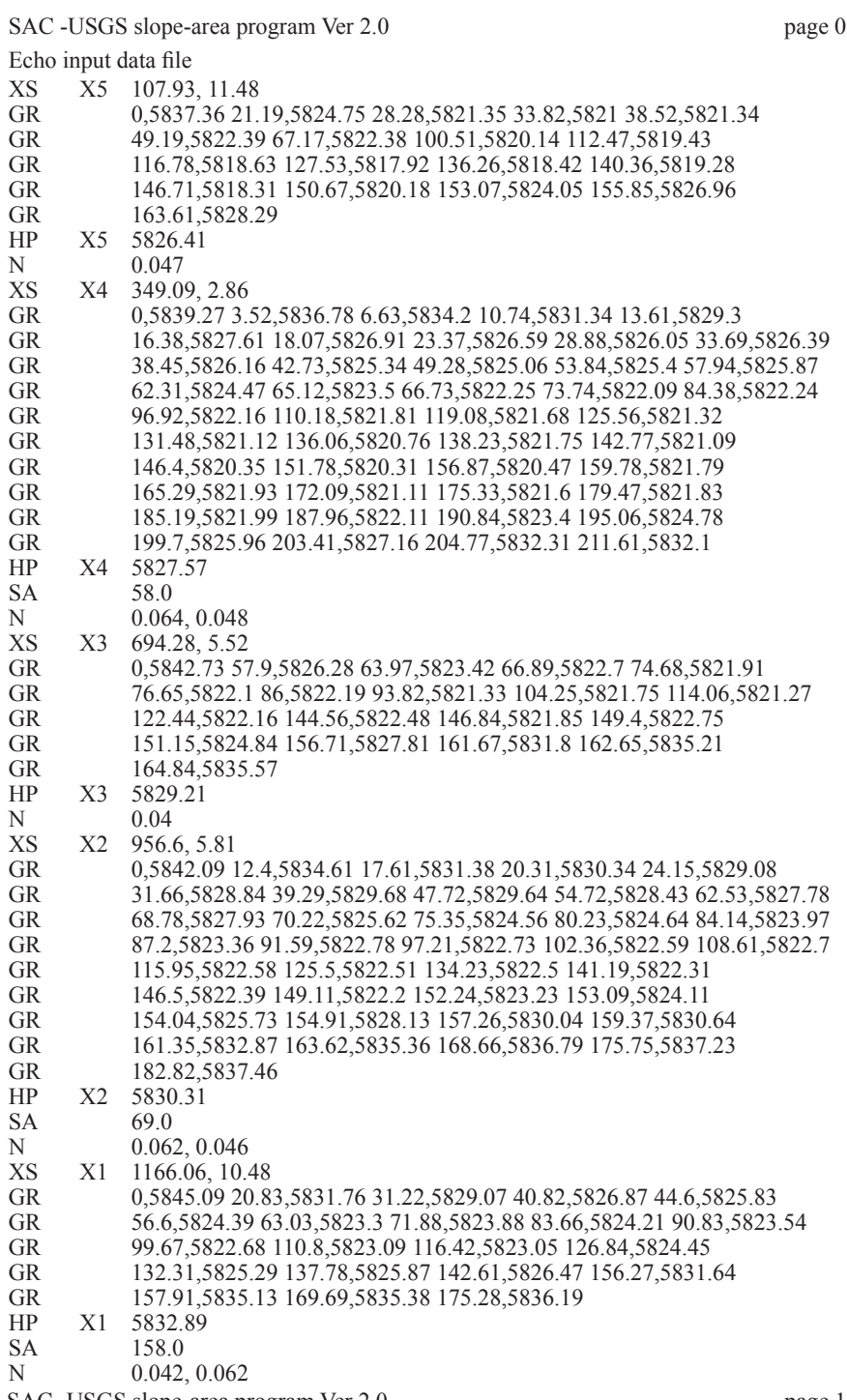

page 0

SAC -USGS slope-area program Ver 2.0

07105530 Reach

\section{DISCHARGE COMPUTATIONS}

dH,fall length Discharge Spread HF $\quad$ CX $\quad$ RC $\quad$ RX $\quad$ ER

$\begin{array}{lrrrrrrrrr} & & (\mathrm{ft}) & (\mathrm{ft}) & (\mathrm{cfs}) & (\%) & (\mathrm{ft}) & & & \\ \mathrm{X} 1 & -\mathrm{X} 2 & 2.58 & 210 . & 7684 . & 0 & 1.288 & 1.000 & 1.003 & 0.000 \\ \mathrm{X} 2 & -\mathrm{X} 3 & 1.10 & 262 . & 5139 . & 4 & 1.150 & 0.977 & 0.000 & -0.086 \\ \mathrm{X} 3 & -\mathrm{X} 4 & 1.64 & 345 . & 5818 . & 11 & 1.821 & 0.943 & 0.000 & -0.198 \\ \mathrm{X} 4 & -\mathrm{X} 5 & 1.16 & 241 . & 4922 . & 0 & 1.043 & 1.000 & 0.112 & 0.000 \\ \mathrm{X} 1 & -\mathrm{X} 3 & 3.68 & 472 . & 6566 . & 2 & 2.818 & 0.989 & 0.335 & -0.058 \\ \mathrm{X} 2 & -\mathrm{X} 4 & 2.74 & 608 . & 5515 . & 8 & 2.960 & 0.959 & 0.000 & -0.148 \\ \mathrm{X} 3 & -\mathrm{X} 5 & 2.80 & 586 . & 5392 . & 5 & 2.815 & 0.972 & 0.050 & -0.110 \\ \mathrm{X} 1 & -\mathrm{X} 4 & 5.32 & 817 . & 6306 . & 5 & 4.737 & 0.973 & 0.184 & -0.121 \\ \mathrm{X} 2 & -\mathrm{X} 5 & 3.90 & 849 . & 5317 . & 5 & 3.968 & 0.973 & 0.034 & -0.103 \\ \mathrm{X} 1 & -\mathrm{X} 5 & 6.48 & 1058 . & 5972 . & 4 & 5.785 & 0.980 & 0.165 & -0.089\end{array}$

Definitions:

Spread, the percent difference between discharge computed with no expansion loss $(\mathrm{k}=0)$ and discharge computed with full expansion loss $(\mathrm{k}=1.0)$, divided by the discharge computed with full expansion loss

$\mathrm{HF}$, friction head- $\mathrm{HF}=$ sum of $\mathrm{Q}^{*} \mathrm{Q} * \mathrm{~L} /\left(\mathrm{K} 1{ }^{*} \mathrm{~K} 2\right)$ over subreaches; $\mathrm{Q}$, discharge; $\mathrm{L}$, reach length; $\mathrm{K} 1$, upstream section conveyance; $\mathrm{K} 2$, downstream section conveyance

$\mathrm{CX}$, the computed discharge divided by the discharge computed with no expansion loss $(\mathrm{k}=0)$

RC, velocity head change in contracting section divided by friction head

$\mathrm{RX}$, velocity head change in expanding section divided by friction head

ER, warnings, *-fall <'0.5ft, @-conveyance ratio exceeded, \#-reach too short error, 1-negative or 0 fall

******, terms that can not be computed because' of strong expansion in reach

\begin{tabular}{|c|c|c|c|c|c|c|c|c|}
\hline \multicolumn{2}{|l|}{$\begin{array}{l}\text { I.D. } \quad \mathrm{X} 5 \\
\text { Ref.distance }\end{array}$} & \multirow{3}{*}{$\begin{array}{l}108 . \mathrm{ft} \\
\text { Area }\end{array}$} & \multicolumn{2}{|c|}{$\begin{array}{c}\text { Velocity head } \\
\text { Q/K }\end{array}$} & \multirow{3}{*}{$\begin{array}{c}0.99 \mathrm{ft} \\
0.0068 \\
\text { Hydraulic } \\
\text { radius }\end{array}$} & \multicolumn{3}{|c|}{$\begin{array}{c}\text { Discharge 5972.cfs } \\
\text { Alpha } 1.000\end{array}$} \\
\hline $\begin{array}{l}\text { Sub V } \\
\text { area su }\end{array}$ & $\mathrm{n}$ & & & & & & & F \\
\hline no. & & & & & & & & \\
\hline 587 & & & & & & 100 & 8.0 & \\
\hline otal 5826.41 & -- & 748. & 134. & 140 & 5.36 & 72.664100 . & 8.0 & 0.0 \\
\hline
\end{tabular}
Definitions:

n, Manning's coefficient of roughness $\mathrm{Q} / \mathrm{K}=$ discharge/conveyance

F, Froude number $\mathrm{F}=\mathrm{Ki} * \mathrm{Q} /\left(\mathrm{K}^{*} \mathrm{~A} \operatorname{sqrt}(\mathrm{g} *(\mathrm{Ai} / \mathrm{TWi})) ; \mathrm{Q}\right.$, discharge; $\mathrm{A}$, Total crosssection area; $\mathrm{g}$, acceleration of gravity; $\mathrm{Ai}$, sub-section area; $\mathrm{TW}$, sub- section top width

SAC -USGS slope-area program Ver 2.0

page 2

07105530

CROSS SECTION PROPERTIES

\begin{tabular}{|c|c|c|c|c|c|c|c|c|}
\hline $\begin{array}{l}\text { I.D. } \quad \text { X4 } \\
\text { Ref.distance }\end{array}$ & & 349.ft & \multicolumn{2}{|c|}{$\begin{array}{c}\text { Velocity head } \\
\text { Q/K }\end{array}$} & $\begin{array}{c}0.82 \mathrm{ft} \\
0.0060\end{array}$ & \multicolumn{3}{|c|}{$\begin{array}{c}\text { Discharge } 5972 . c f s \\
\text { Alpha } 1.085\end{array}$} \\
\hline $\begin{array}{l}\text { Sub Water } \\
\text { area surface } \\
\text { no. el.(ft) }\end{array}$ & $\mathrm{n}$ & $\begin{array}{l}\text { Area } \\
\text { (sq.ft) }\end{array}$ & $\begin{array}{l}\text { Top } \\
\text { width } \\
\text { (ft) }\end{array}$ & $\begin{array}{l}\text { Wetted } \\
\text { perimeter } \\
(\mathrm{ft})\end{array}$ & $\begin{array}{l}\text { Hydraulic } \\
\text { radius } \\
\text { (ft) }\end{array}$ & $\begin{array}{l}\text { Conveyance } \\
\text { x } 0.001 \\
(\mathrm{cfs}) \quad \%\end{array}$ & $\begin{array}{l}\text { Vel. } \\
\text { (fps) }\end{array}$ & F \\
\hline $1 \quad 5827.57$ & 0.064 & 66.4 & 41.5 & 41.8 & 159 & $2.103 \quad 3$. & 2.5 & 0.34 \\
\hline 5827 & 0.048 & 790.8 & & & & 75.01097. & 7.3 & \\
\hline Total 5827.57 & - & 857. & 87. & 190 & 4 & 77.113100 & 7.0 & 0.5 \\
\hline $\begin{array}{l}\text { D. } \quad \mathrm{X} \\
\text { Ref.distance }\end{array}$ & & 694.ft & & . & 0.0051 & $\begin{array}{l}\text { ischarge } \\
\text { Alpha }\end{array}$ & 000 & \\
\hline $\begin{array}{l}\text { Sub Water } \\
\text { area surface } \\
\text { no. el.(ft) }\end{array}$ & $\mathrm{n}$ & $\begin{array}{l}\text { Area } \\
\text { (sq.ft) }\end{array}$ & $\begin{array}{l}\text { Top } \\
\text { width } \\
\text { (ft) }\end{array}$ & $\begin{array}{c}\text { Wetted } \\
\text { perimeter } \\
(\mathrm{ft})\end{array}$ & $\begin{array}{l}\text { Hydraulic } \\
\text { radius } \\
\text { (ft) }\end{array}$ & $\begin{array}{l}\text { Conveyance } \\
\text { x } 0.001 \\
(\mathrm{cfs}) \%\end{array}$ & $\begin{array}{l}\text { Vel. } \\
\text { (fps) }\end{array}$ & F \\
\hline 5829.21 & 0.040 & 679.9 & 110.3 & & 5.96 & 83.234100 . & 8.8 & 0. \\
\hline Total 5829.21 & -- & 680. & 10. & 11 & 5.9 & $83.234 \quad 100$ & 8.8 & 0.6 \\
\hline $\begin{array}{l}\text { I.D. } \quad \mathrm{X} 2 \\
\text { Ref.distance }\end{array}$ & & 957.ft & & $\begin{array}{l}\text { city head } \\
Q / K\end{array}$ & .0068 & $\begin{array}{r}\text { Discharge } \\
\text { Alpha }\end{array}$ & $\begin{array}{r}597 \\
.133\end{array}$ & 72.ct \\
\hline $\begin{array}{l}\text { Sub Water } \\
\text { area surface } \\
\text { no. el.(ft) }\end{array}$ & $\mathrm{n}$ & $\begin{array}{l}\text { Area } \\
\text { (sq.ft) }\end{array}$ & $\begin{array}{l}\text { Top } \\
\text { width } \\
\text { (ft) }\end{array}$ & $\begin{array}{c}\text { Wetted } \\
\text { perimeter } \\
(\mathrm{ft})\end{array}$ & $\begin{array}{l}\text { Hydraulic } \\
\text { radius } \\
\text { (ft) }\end{array}$ & $\begin{array}{l}\text { Conveyance } \\
\text { x } 0.001 \\
\text { (cfs) } \%\end{array}$ & $\begin{array}{l}\text { Vel. } \\
\text { (fps) }\end{array}$ & F \\
\hline 5830.31 & 0.062 & 67.6 & 48.3 & 48. & 1.3 & 2.016 & 2.5 & 0.37 \\
\hline 5830 & 0.046 & 618.6 & 88. & & & 70.365 & 9.4 & 0. \\
\hline otal 5830.31 & $\cdots$ & 686. & 137. & 143. & 4.80 & $72.382 \quad 100$ & 8.7 & 0.69 \\
\hline
\end{tabular}

Definitions:

$\mathrm{n}$, Manning's coefficient of roughness $\mathrm{Q} / \mathrm{K}=$ discharge/conveyance

$\mathrm{F}, \quad$ Froude number $\mathrm{F}=\mathrm{Ki} * \mathrm{Q} /\left(\mathrm{K}^{*} \mathrm{~A}\right.$ sqrt $\left(\mathrm{g}^{*}(\mathrm{Ai} / \mathrm{TWi})\right)$; $\mathrm{Q}$, discharge; $\mathrm{A}$, Total crosssection area; $\mathrm{g}$, acceleration of gravity; $\mathrm{Ai}$, sub-section area; TWi, sub- section top width

SAC -USGS slope-area program Ver 2.0

page 3 07105530

\begin{tabular}{|c|c|c|c|c|c|c|c|c|c|}
\hline \multicolumn{10}{|c|}{ OSS SECTION PROPERTIES } \\
\hline \multicolumn{2}{|c|}{$\begin{array}{l}\text { I.D. X1 } \\
\text { Ref.distance }\end{array}$} & & $1166 . \mathrm{ft}$ & \multicolumn{2}{|c|}{$\begin{array}{c}\text { Velocity head } \\
\text { Q/K }\end{array}$} & $\begin{array}{c}0.55 \mathrm{ft} \\
0.0020\end{array}$ & \multicolumn{3}{|c|}{ Discharge 5972.cfs } \\
\hline $\begin{array}{l}\text { Sub } \\
\text { area }\end{array}$ & $\begin{array}{l}\text { Water } \\
\text { surface }\end{array}$ & $\mathrm{n}$ & & $\begin{array}{l}\text { Top } \\
\text { width }\end{array}$ & & $\begin{array}{l}\text { Hydraulic } \\
\text { radius }\end{array}$ & $\begin{array}{l}\mathrm{Co} \\
\mathrm{x} 0 .\end{array}$ & $\mathrm{Ve}$ & F \\
\hline no. & el (ft & & & (ft) & & & $\%$ & $(\mathrm{fps}$ & \\
\hline 1 & 5832.89 & 0.042 & 1001.6 & 135.5 & 138 & 7.2 & 132.659100. & 6.0 & 0.39 \\
\hline 2 & 0.00 & 0.000 & 0.0 & 0.0 & & $\mathrm{Na}$ & 0.000 & $* * * *$ & *** \\
\hline Total & 5832.89 & --- & 1002. & 135. & 139. & 7.21 & 132.659100. & 6.0 & 0.39 \\
\hline
\end{tabular}

Definitions:

n, Manning's coefficient of roughness $\mathrm{Q} / \mathrm{K}=$ discharge/conveyance

$\mathrm{F}, \quad$ Froude number $\mathrm{F}=\mathrm{Ki} * \mathrm{Q} /\left(\mathrm{K}^{*} \mathrm{~A} \operatorname{sqrt}\left(\mathrm{g}^{*}(\mathrm{Ai} / \mathrm{TWi})\right)\right.$; $\mathrm{Q}$, discharge; $\mathrm{A}$, Total crosssection area; $\mathrm{g}$, acceleration of gravity; $\mathrm{Ai}$, sub-section area; TWi, sub- section top width

Figure 12. The Slope-Area Computation Graphical User Interface (SACGUI) model output summary for Fountain Creek below U.S. Highway 24 in Colorado Springs, Colorado. 


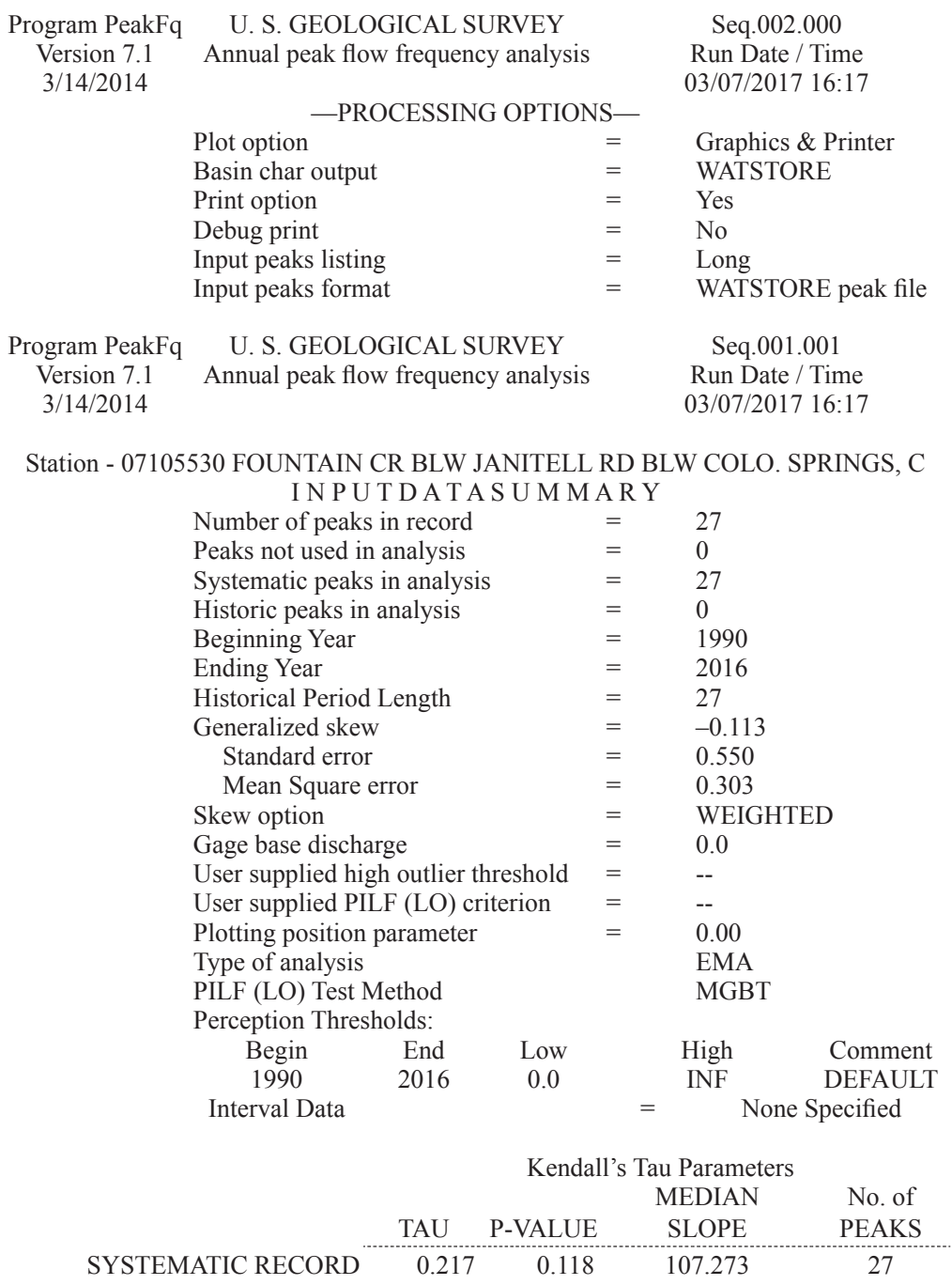

ANNUAL FREQUENCY CURVE PARAMETERS — LOG-PEARSON TYPE III

EMA W/O REG. INFO

EMA W/REG. INFO

EMA ESTIMATE OF MSE OF SKEW W/O REG. INFO (AT-SITE)

LOGARITHMIC

STANDARD

\begin{tabular}{ccc} 
& \multicolumn{3}{c}{ LOGARITHMIC } \\
MEAN & STANDARD & \\
\hline 3.7920 & DEVIATION & SKEW \\
3.7920 & 0.1861 & -0.399 \\
& 0.1861 & -0.279
\end{tabular}

EMA ESTIMATE OF MSE OF SKEW W/SYSTEMATIC ONLY (AT-SITE)

0.2194

0.2194
ANNUAL FREQUENCY CURVE—DISCHARGES AT SELECTED EXCEEDANCE PROBABILITIES

\begin{tabular}{cccccc} 
ANNUAL & EMA W/ & EMA W/O & \multicolumn{3}{c}{$<$ FOR EMA ESTIMATES $>$} \\
EXCEEDANCE & REG INFO & $\begin{array}{c}\text { REG INFO } \\
\text { PROBABILITY }\end{array}$ & $\begin{array}{c}\text { ESTIMATE } \\
\text { ESTIMATE }\end{array}$ & $\begin{array}{c}\text { OF EST. } \\
\text { ESTIM CONFIDENCE }\end{array}$ & $\begin{array}{c}\text { LOWER } \\
\text { INTERVALS } \\
\text { UPPER }\end{array}$ \\
0.9950 & 1837. & 1751. & 0.0116 & 734.0 & 2594.0 \\
0.9900 & 2096. & 2020. & 0.0088 & 972.5 & 2852.0 \\
0.9500 & 2964. & 2926. & 0.0041 & 1883.0 & 3739.0 \\
0.9000 & 3537. & 3523. & 0.0029 & 2513.0 & 4347.0 \\
0.8000 & 4349. & 4366. & 0.0020 & 3374.0 & 5235.0 \\
$\mathbf{0 . 6 6 6 7}$ & $\mathbf{5 2 3 8 .}$ & 5278. & $\mathbf{0 . 0 0 1 6}$ & 4256.0 & 6237.0 \\
$\mathbf{0 . 5 0 0 0}$ & $\mathbf{6 3 1 9 .}$ & 6373. & $\mathbf{0 . 0 0 1 4}$ & 5264.0 & 7497.0 \\
0.4292 & 6814. & 6869. & 0.0014 & 5710.0 & 8092.0 \\
0.2000 & 8925. & 8936. & 0.0015 & 7525.0 & 10880.0 \\
0.1000 & 10570. & 10500. & 0.0018 & 8870.0 & 13580.0 \\
0.0400 & 12570. & 12330. & 0.0027 & 10350.0 & 17680.0 \\
0.0200 & 13990. & 13590. & 0.0037 & 11260.0 & 21150.0 \\
0.0100 & 15360. & 14780. & 0.0049 & 12030.0 & 24990.0 \\
0.0050 & 16700. & 15910. & 0.0064 & 12690.0 & 29260.0 \\
0.0020 & 18420. & 17330. & 0.0088 & 13400.0 & 35740.0
\end{tabular}

Figure 13. The PeakF0 output summary for Fountain Creek below U.S. Highway 24 in Colorado Springs, Colorado. (Highlighted values indicate the annual exceedance probability [0.5000] that is greater than this flood event and the annual exceedance probability [0.667] that is less than this event.) 


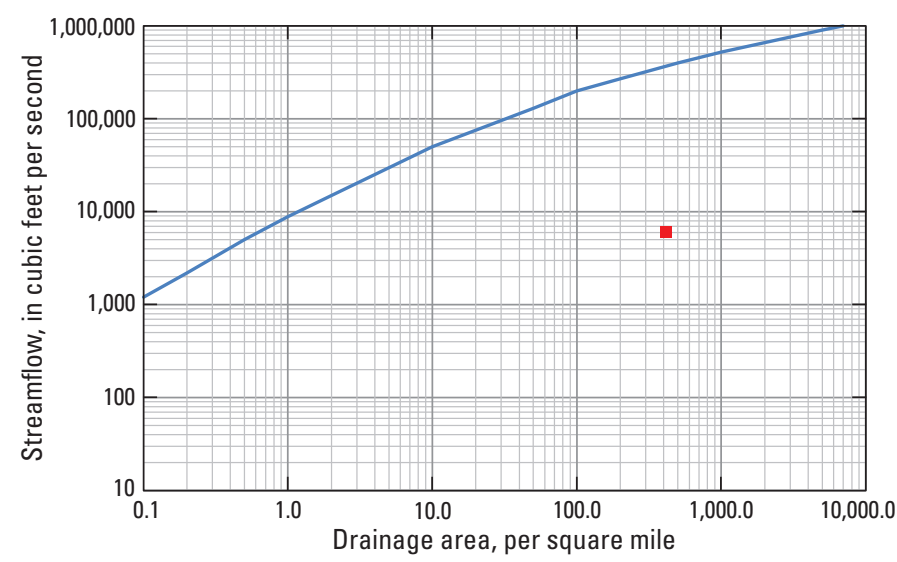

EXPLANATION

- Envelope curve for Region 12

- Fountain Creek below U.S. Highway 24

in Colorado Springs, Colorado

Figure 14. The envelope curve for Region 12 from Crippen and Bue (1977) with the flood of August 29, 2016, on Fountain Creek below U.S. Highway 24 in Colorado Springs, Colorado.

\section{Flood Frequency of Peak Discharge}

The annual exceedance probability discharge for the Fountain Creek site from PeakFQ is shown in figure 13. The 0.6667 annual exceedance probability discharge (1.5-year flood) is $5,240 \mathrm{ft}^{3} / \mathrm{s}$, using three significant figures, and the 0.5 annual exceedance probability discharge (2-year flood) is $6,320 \mathrm{ft}^{3} / \mathrm{s}$. From log-linear interpolation of PeakFQ floodfrequency output following Mason (2012), the August 29, 2016, flood at the Fountain Creek site had an estimated annual exceedance probability of 0.5505 (return period equal to the 1.8-year flood). Following Mason (2012), a 95-percent confidence interval for the true exceedance probability of this flood, the 16th largest flood in 27 years at USGS streamgage 07105530 , extends from 0.7452 to 0.3880 (return period from the 1.3-year flood to the 2.6-year flood).

Based on the at-site drainage area of $412 \mathrm{mi}^{2}$, the unit discharge for the August 29, 2016, flood at the Fountain Creek site was $14.5 \mathrm{ft}^{3} / \mathrm{s}$ per square mile. The August 29, 2016, flood at the Fountain Creek site relative to the envelope curve for Region 12 from Crippen and Bue (1977) is shown in figure 14. The flood-frequency analysis provides evidence that this was a common flood event and when plotted with the envelope curve for Region 12 by Crippen and Bue (1977), it plots almost two orders of magnitude below the envelope curve, confirming the high probability of a flood of this magnitude.

Figure 15 (following page). The current (2017) stage-discharge rating for the U.S. Geological Survey streamgage 07105530 with the August 29, 2016, flood at Fountain Creek below U.S. Highway 24 in Colorado Springs, Colorado. [GH, gage height; SV, site visit identification number; period, October 1, 2016 to March 6, 2017]

\section{Peak Stage}

Cross section 1 was located closest to the U.S. Highway 24 bridge so that location was used as the reference stage. Cross section 1 is located at 14,090,603.11 ft northing and $1,699,180.53 \mathrm{ft}$ easting, and the peak stage from figure 12 was $5,832.89 \mathrm{ft}$.

The USGS streamgage 07105530 , which is located approximately $370 \mathrm{ft}$ upstream from cross section 1, recorded a streamgage height of $13.88 \mathrm{ft}$ at 2:55 p.m. Mountain Daylight Time on August 29, 2016 (USGS, 2016b). From the survey of reference marks 5 and 10 at the USGS streamgage 07105530 , the streamgage datum elevation was $5,821.15 \mathrm{ft}$; therefore, the peak stage at USGS streamgage 07105530 was $5,835.03 \mathrm{ft}$.

At USGS streamgage 07105530, the USGS has developed a stage-discharge rating that is used to report discharge based on a real-time stage reading from a stage measurement at the streamgage. A stage-discharge rating is developed by plotting a number of measurements over a range of discharges and corresponding stages and applying a best-fit line (Rantz and others, 1982). The current stage-discharge rating for the USGS streamgage 07105530 is plotted with the August 29, 2016 , flood on figure 15. Based on the results of this measurement, the stage-discharge rating was revised and extended so that the current rating fits this measurement because this will be the largest recent measurement.

\section{Summary}

The U.S. Geological Survey (USGS), in cooperation with the Colorado Department of Transportation, determined the peak discharge, annual exceedance probability (flood frequency), and peak stage of two floods that took place on Big Cottonwood Creek at U.S. Highway 50 near Coaldale, Colorado (hereafter referred to as the "Big Cottonwood Creek site"), on August 23, 2016, and on Fountain Creek below U.S. Highway 24 in Colorado Springs, Colo. (hereafter referred to as the "Fountain Creek site"), on August 29, 2016. Collection and computation of flood data, such as peak discharge, annual exceedance probability, and peak stage at structures critical to Colorado's infrastructure are an important addition to the streamflow data collected annually by the USGS. A one-dimensional hydraulic model was used to estimate the peak discharge. To define the flood frequency of each flood, peak-streamflow regionalregression equations or statistical analyses of USGS streamgage record were used to estimate annual exceedance probability of the peak discharge. A survey of the high-water mark profile was used to determine the peak stage, and the limitations and accuracy of each component also are presented in this report. The Slope-Area Computation Graphical User Interface (SACGUI) was used to compute the peak discharge.

Hourly precipitation data provide evidence that the August 23, 2016, flood event at the Big Cottonwood Creek site was caused by a local storm 5 hours in duration. This storm 


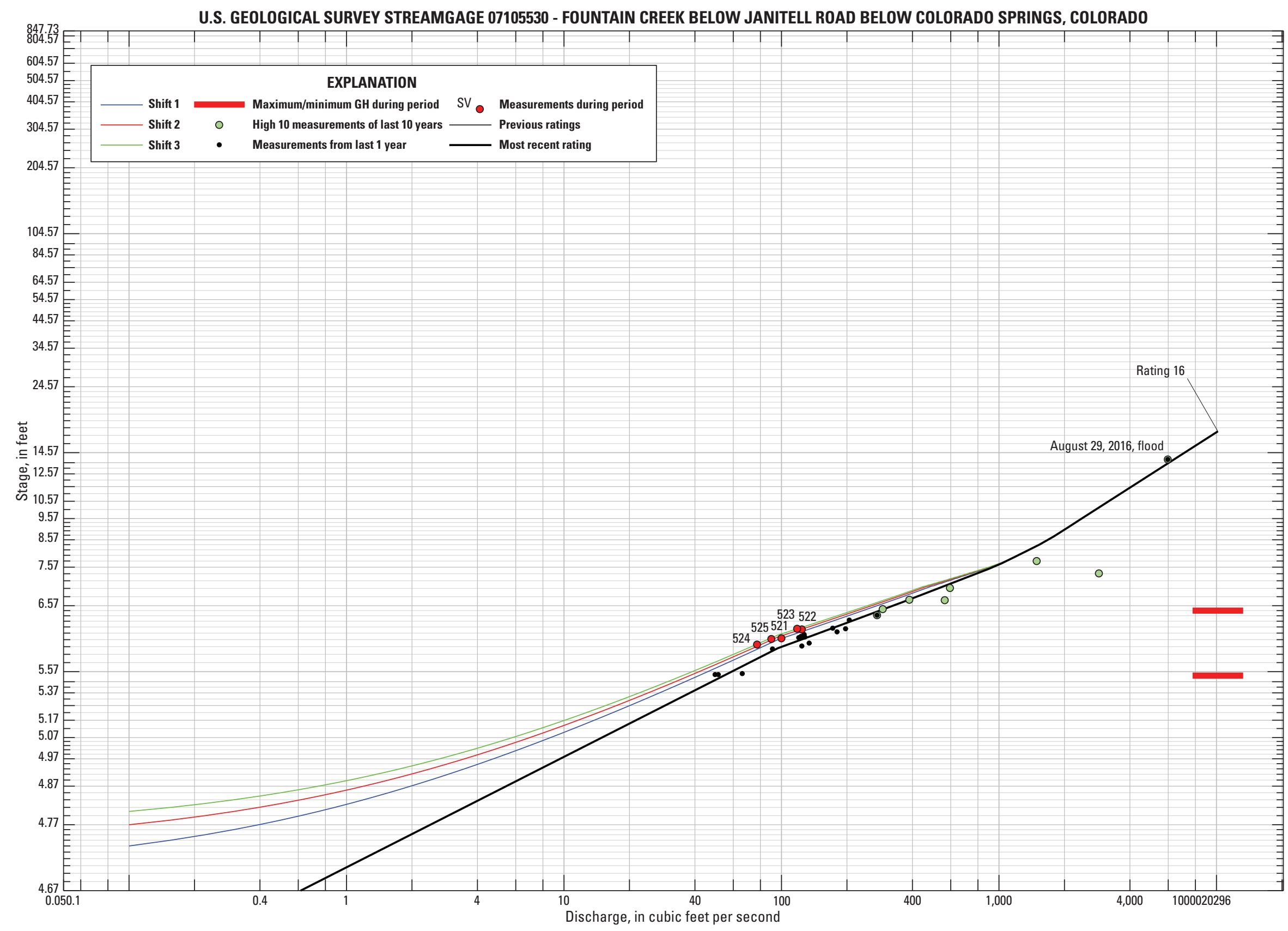


had an annual exceedance probability of 1.0 (1-year storm). The USGS personnel identified, flagged, and surveyed a total of 49 high-water marks at the Big Cottonwood Creek site. The USGS personnel documented the condition of each cross section and estimated the Manning roughness coefficients in the field for each cross section based on the Cowan method. A slope-area indirect discharge measurement for five cross sections was carried out at the Big Cottonwood Creek site to estimate the peak discharge of the August 23, 2016, flood.

The peak discharge of the August 23, 2016, flood at the Big Cottonwood Creek site was 917 cubic feet per second $\left(\mathrm{ft}^{3} / \mathrm{s}\right)$ with a measurement quality of poor (uncertainty plus or minus 25 percent or greater). The August 23, 2016, flood at the Big Cottonwood Creek site had an annual exceedance probability of less than 0.01 (return period greater than the 100-year flood) and greater than 0.005 (return period less than the 200-year flood). The Big Cottonwood Creek site is downstream from the Hayden Pass Fire burn area, which dramatically altered the hydrology of the watershed and caused this statistically rare (low probability) flood from a statistically common (high probability) storm. The peak stage at cross section 1, located nearest to the U.S. Highway 50 culvert, was 6,438.32 feet (ft).

Hourly precipitation data provide evidence that the August 29, 2016, flood event at the Fountain Creek site was caused by a local storm 11 hours in duration. This storm had an annual exceedance probability of 1.0 (1-year storm). The USGS personnel identified, flagged, and documented a total of 102 high-water marks at the Fountain Creek site on August 30-31, 2016, and September 21, 2016. The USGS personnel surveyed high-water marks and cross sections on September 21, 2016. The USGS personnel documented the condition of each cross section and estimated the Manning roughness coefficients in the field for each cross section based on the Cowan method. A slope-area indirect discharge measurement for five cross sections was carried out at the Fountain Creek site to estimate the peak discharge of the August 29, 2016, flood.

The peak discharge of the August 29, 2016, flood at the Fountain Creek site was 5,970 $\mathrm{ft}^{3} / \mathrm{s}$ with a measurement quality of poor (uncertainty plus or minus 25 percent or greater). The August 29, 2016, flood at the Fountain Creek site had an estimated annual exceedance probability of 0.5505 (return period equal to the 1.8-year flood). The peak stage at cross section 1 , which is nearest to the U.S. Highway 24 bridge, was $5,832.89 \mathrm{ft}$. The peak stage at USGS streamgage 07105530 was $5,835.03 \mathrm{ft}$.

\section{References Cited}

Benson, M.A., and Dalrymple, Tate, 1967, General field and office procedures for indirect discharge measurements: U.S. Geological Survey Techniques of Water-Resources Investigations, book 3, chap. A1, $30 \mathrm{p}$.

Bradley, D.N., 2012, Slope-area computation program graphical user interface 1.0-A preprocessing and postprocessing tool for estimating peak flood discharge using the slope-area method: U.S. Geological Survey Fact Sheet 2012-3112, 4 p.

Capesius, J.P., and Stephens, V.C., 2009, Regional regression equations for estimation of natural streamflow statistics in Colorado: U.S. Geological Survey Scientific Investigations Report 2009-5136, 46 p.

Chow, V.T., 1959, Open-channel hydraulics: New York, McGraw-Hill, $680 \mathrm{p}$.

Cowan, W.L., 1956, Estimating hydraulic roughness coefficients: Agricultural Engineering, v. 37, no. 7, p. 473-475.

Crippen, J.R., and Bue, C.D., 1977, Maximum floodflows in the conterminous United States: U.S. Geological Survey Water-Supply Paper 1887, 52 p.

Dalrymple, Tate, and Benson, M.A., 1968, Measurement of peak discharge by the slope-area method: U.S. Geological Survey Techniques of Water-Resources Investigations, book 3, chap. A2, 12 p.

Davidian, Jacob, 1984, Computation of water-surface profiles in open channels: U.S. Geological Survey Techniques of Water-Resources Investigations, book 3, chap. A15, 48 p.

Environmental Systems Research Institute, Inc. (Esri), 2016, ArcGIS - A complete integrated system: Redlands, Calif, Esri, accessed November 18, 2016, at http://www.esri.com/ software/arcgis/.

Fulford, J.M., 1994, User's guide to SAC, a computer program for computing discharge by slope-area method: U.S. Geological Survey Open-File Report 94-360, 31 p.

Interagency Advisory Committee on Water Data, 1982, Subcommittee on Hydrology, Hydrologic Frequency Analysis Work Group, Guidelines for determining flood flow frequency: Reston, Va., Hydrology Subcommittee Bulletin 17B, 28 p., and appendixes, accessed March 7, 2017, at https://water.usgs.gov/osw/bulletin17b/dl_flow.pdf. 
Interagency Advisory Committee on Water Data, 2014, Subcommittee on Hydrology, Hydrologic Frequency Analysis Work Group, Determining flood frequency using EMA, Frequently asked questions, accessed March 7, 2017, at https://acwi.gov/hydrology/Frequency/b17c/faqs-b17c.html.

Kimbrough, R.A., and Holmes, R.R., Jr., 2015, Flooding in the South Platte River and Fountain Creek Basins in eastern Colorado, September 9-18, 2013: U.S. Geological Survey Scientific Investigations Report 2015-5119, 33 p., accessed December 7, 2016, at http://dx.doi.org/10.3133/ $\operatorname{sir} 20155119$.

Koenig, T.A., Bruce, J.L., O’Connor, J.E., McGee, B.D., Holmes, R.R., Jr., Hollins, Ryan, Forbes, B.T., Kohn, M.S., Schellekens, M.F., Martin, Z.W., and Peppler, M.C., 2016, Identifying and preserving high-water mark data: U.S. Geological Survey Techniques and Methods, book 3, chap. A24, 47 p., accessed December 7, 2016, at http://dx.doi. org/10.3133/tm3A24.

Kohn, M.S., Fulton, J.W., Williams, C.A., and Stogner, R.W., Sr., 2014, Remediation scenarios for attenuating peak flows and reducing sediment transport in Fountain Creek, Colorado, 2013: U.S. Geological Survey Scientific Investigations Report 2014-5019, 62 p., accessed December 7, 2016, at http://dx.doi.org/10.3133/sir20145019.

Kohn, M.S., Stevens, M.R., Harden, T.M., Godaire, J.E., Klinger, R.E., and Mommandi, Amanullah, 2016, Paleoflood investigations to improve peak-streamflow regionalregression equations for natural streamflow in eastern Colorado, 2015: U.S. Geological Survey Scientific Investigations Report 2016-5099, 58 p., accessed December 7, 2016, at http://dx.doi.org/10.3133/sir20165099.

Mason, R.R., Jr., 2012, Computation of annual exceedance probability (AEP) for characterization of observed flood peaks: U.S. Geological Survey Scientific Office of Surface Water Technical Memorandum 2013.01, 7 p., accessed March 9, 2017, at https://water.usgs.gov/admin/memo/SW/ sw13.01.pdf.

National Weather Service, 2016, Advanced hydrologic prediction service hourly precipitation analysis website: accessed November 18, 2016, at http://www.srh.noaa.gov/ridge2/ RFC_Precip/.
Perica, S., Martin, D., Pavlovic, S., Roy, I., St. Laurent, M., Trypaluk, C., Unruh, D., Yekta, M., and Bonnin, G., 2013, Precipitation-frequency atlas of the United States: National Weather Service, National Oceanic and Atmospheric Administration Atlas 14, v. 8, version 2.0; Midwestern States (Colorado, Iowa, Kansas, Michigan, Minnesota, Missouri, Nebraska, North Dakota, Oklahoma, South Dakota, Wisconsin), accessed December 7, 2016, at http://www.nws. noaa.gov/oh/hdsc/PF_documents/Atlas14_Volume8.pdf.

Rantz, S.E., and others, 1982, Measurement and computation of streamflow, volume 2. Computation of discharge: U.S. Geological Survey Water-Supply Paper 2175.

Ries, K.G., III, Steeves, P.A., Coles, J.D., Rea, A.H., and Stewart, D.W., 2004, StreamStats-A U.S. Geological Survey Web application for stream information: U.S. Geological Survey Fact Sheet 2004-3115.

Rydlund, P.H., Jr., and Densmore, B.K., 2012, Methods of practice and guidelines for using survey-grade global navigation satellite systems (GNSS) to establish vertical datum in the United States Geological Survey: U.S. Geological Survey Techniques and Methods, book 11, chap. D1, 102 p. with appendixes.

Stogner, R.W., Sr., 2000, Trends in precipitation and streamflow and changes in stream morphology in the Fountain Creek watershed, Colorado, 1939-99: U.S. Geological Survey Water-Resources Investigations Report 00-4130, $43 \mathrm{p}$.

U.S. Geological Survey (USGS), 2016a, Hayden Pass Fire (Fremont County, CO): U.S. Geological Survey website, accessed December 7, 2016, at https://landslides.usgs.gov/ hazards/postfire_debrisflow/detail.php?objectid=64.

U.S. Geological Survey (USGS), 2016b, National Water Information System-Web Interface: accessed December 6, 2016, at https://dx.doi.org/10.5066/F7P55KJN.

U.S. Geological Survey (USGS), 2016c, The StreamStats program: U.S. Geological Survey website, accessed November 18, 2016, at https://water.usgs.gov/osw/streamstats/.

Veilleux, A.G., Cohn, T.A., Flynn, K.M., Mason, R.R., Jr., and Hummel, P.R., 2014, Estimating magnitude and frequency of floods using the PeakFQ 7.0 program: U.S. Geological Survey Fact Sheet 2013-3108, 2 p. 

Appendixes 
Appendix 1. Survey field Notes from Big Cottonwood Creek at U.S. Highway 50 near Coaldale, Colorado

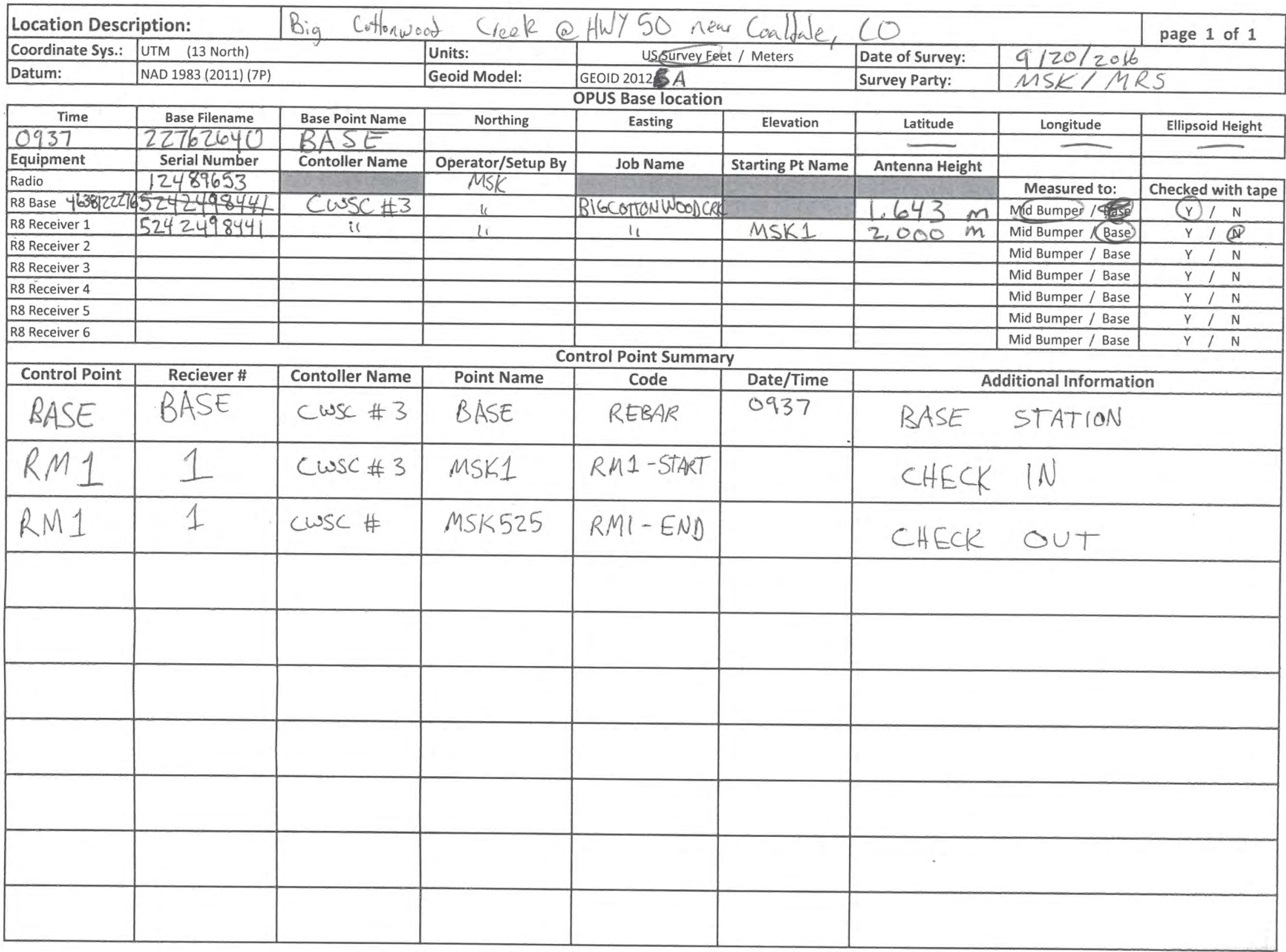

Figure 1-1. The field notes from the September 20, 2016, survey on Big Cottonwood Creek at U.S. Highway 50 near Coaldale, Colorado. 
Appendix 2. Photos of High-Water Marks from Big Cottonwood Creek at U.S. Highway $\mathbf{5 0}$ near Coaldale, Colorado Photos available @ https://doi.org/10.3133/sir20175107 
Appendix 3. Photos of Cross Sections from Big Cottonwood Creek at U.S. Highway $\mathbf{5 0}$ near Coaldale, Colorado Photos available @ https://doi.org/10.3133/sir20175107 


\section{Appendix 4. Manning Roughness Coefficient (n) Assignments and Channel Conditions for the Cross Sections on Big Cottonwood Creek at U.S. Highway 50 near Coaldale, Colorado}

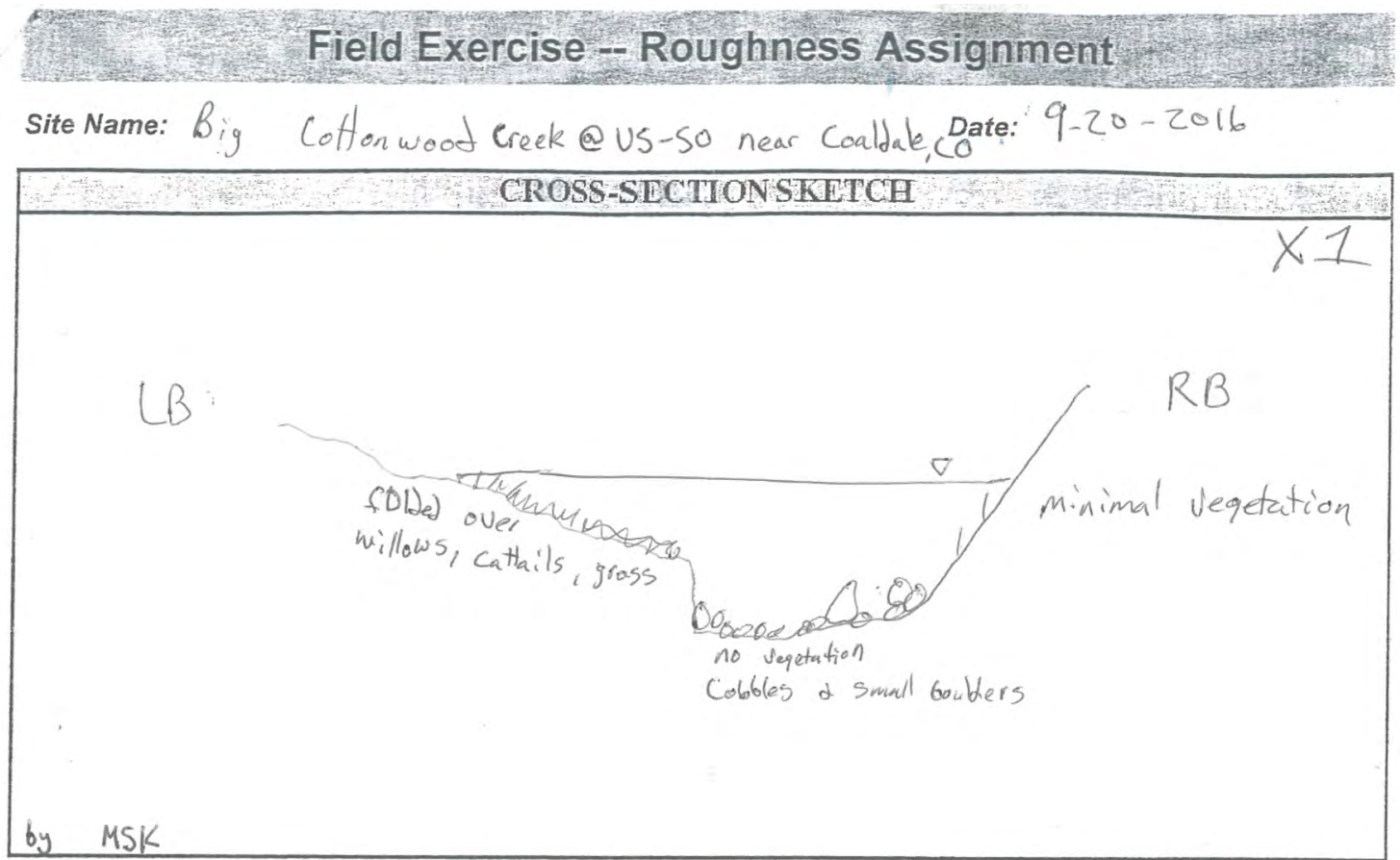

\begin{tabular}{|c|c|c|}
\hline \multicolumn{3}{|c|}{ Assign maintchannel roughness } \\
\hline Factor & Description & Roughness \\
\hline Base (no) & Cobbles a small boulders median size $0,25 \mathrm{~m}$ & 0.050 \\
\hline Irregularity (n1) & moderade irregularity the to Sloughed banks & 0.006 \\
\hline Variability (n2) & frequent cross section Variation & 0.010 \\
\hline Obstruction (n3) & minor obstructions - boublers & 0,005 \\
\hline Vegetation (n4) & Medium vegetation - willows a vegetution mostly & 0.012 \\
\hline Meandering (m) & Minor & 1,00 \\
\hline & Total $=$ & 0.083 \\
\hline
\end{tabular}

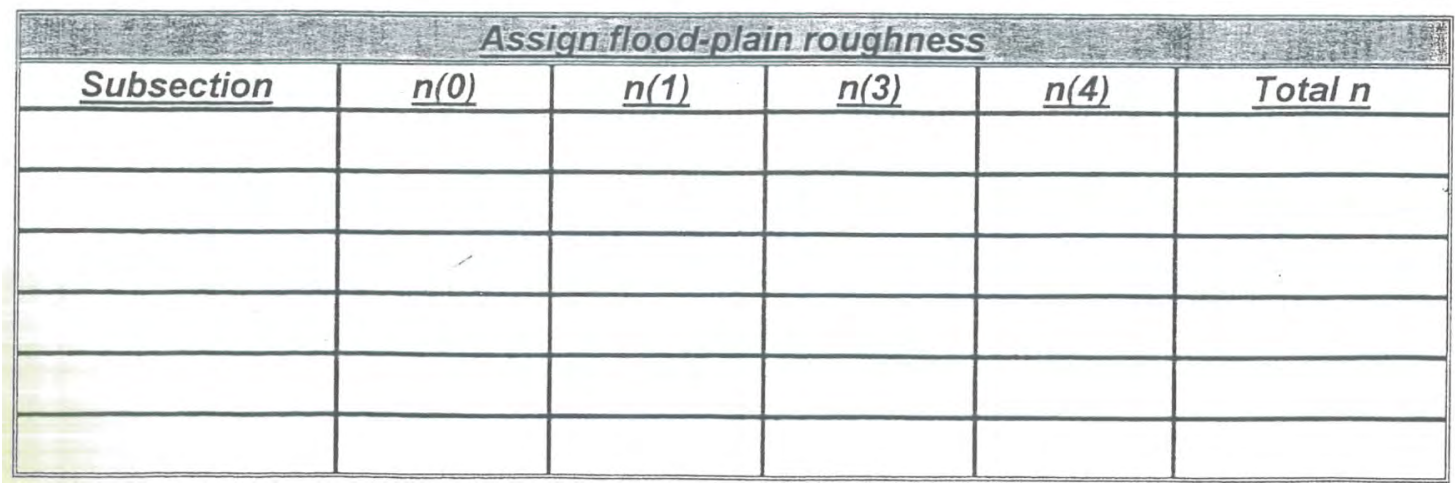

Figure 4-1. The Manning roughness coefficient (n) assignment for cross section 1 on Big Cottonwood Creek at U.S. Highway 50 near Coaldale, Colorado. 


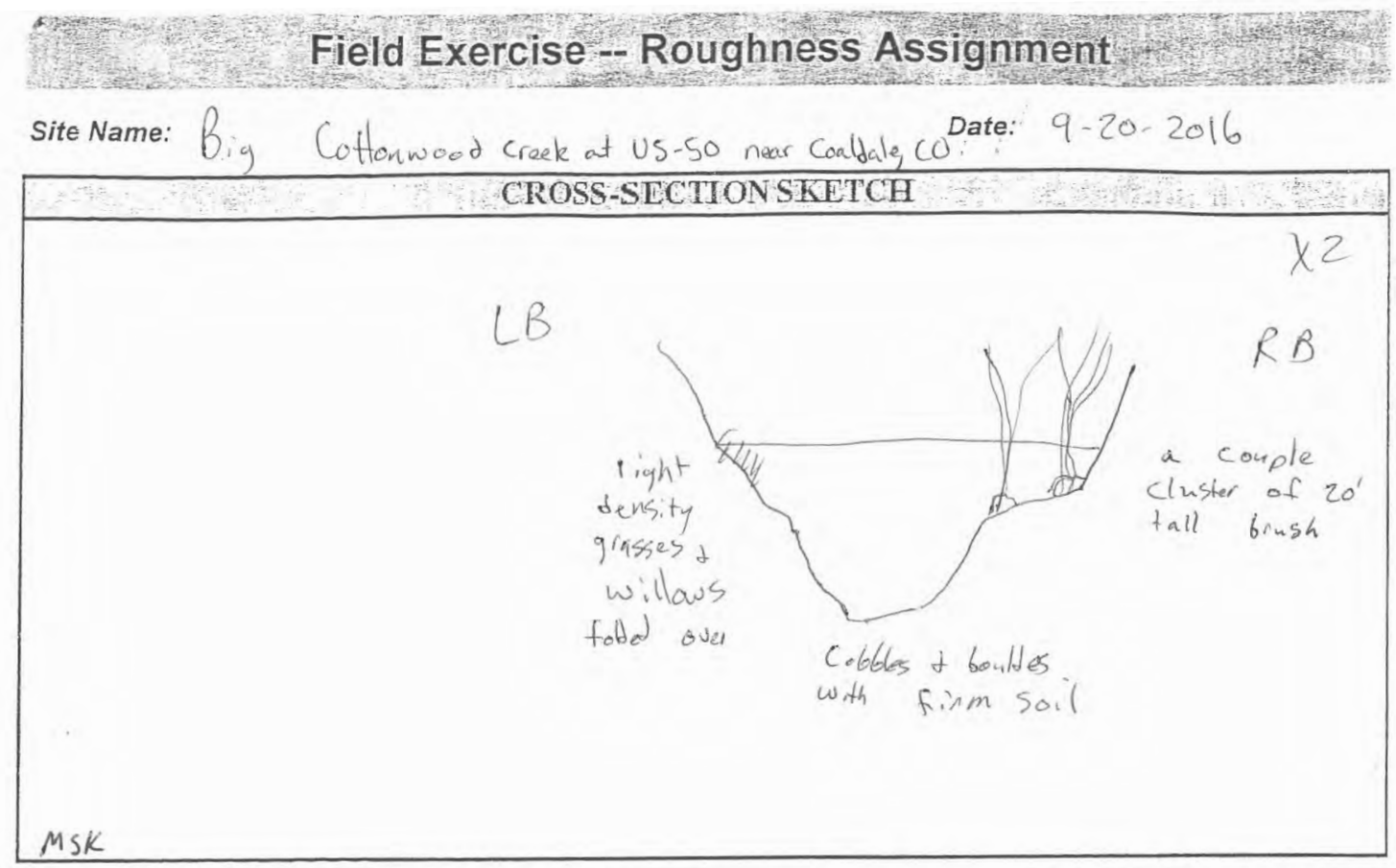

\begin{tabular}{|c|c|c|}
\hline \multicolumn{3}{|c|}{ MIJ Assign mainchannel roughness } \\
\hline Factor & Description & Rouahness \\
\hline Base $(\mathrm{n} 0)$ & Cubbles + boulders with firm soil & 0.0400 \\
\hline Irregularity (n1) & minor Channel irregularty so bank stoughing & 0.004 \\
\hline Variability $(\mathrm{n} 2)$ & high channel & 0.015 \\
\hline Obstruction (n3) & obstrations - debris ples on brush & 0.010 \\
\hline Vegetation (n4) & Vequtition - trush, willens grasses & 0.010 \\
\hline Meandering $(\mathrm{m})$ & Minor & 1,00 \\
\hline & Total $=$ & 0.079 \\
\hline
\end{tabular}

\begin{tabular}{|l|l|l|l|l|l|}
\hline \multicolumn{7}{|c|}{ Assign floodsplain roughness } \\
\hline \hline Subsection & $\underline{n(0)}$ & $\underline{n(1)}$ & $\underline{n}$ & $\underline{n(3)}$ & Total $n$ \\
\hline & & & & & \\
\hline & & & & & \\
\hline & & & & & \\
\hline & & & & & \\
\hline & & & & & \\
\hline & & & & & \\
\hline
\end{tabular}

Figure 4-2. The Manning roughness coefficient ( $\mathrm{n}$ ) assignment for cross section 2 on Big Cottonwood Creek at U.S. Highway 50 near Coaldale, Colorado. 


\section{Field Exercise - Roughness Assignment}

Site Name: Big near Coaldaled co Cleek ot US-50 Date: 9-20-2016

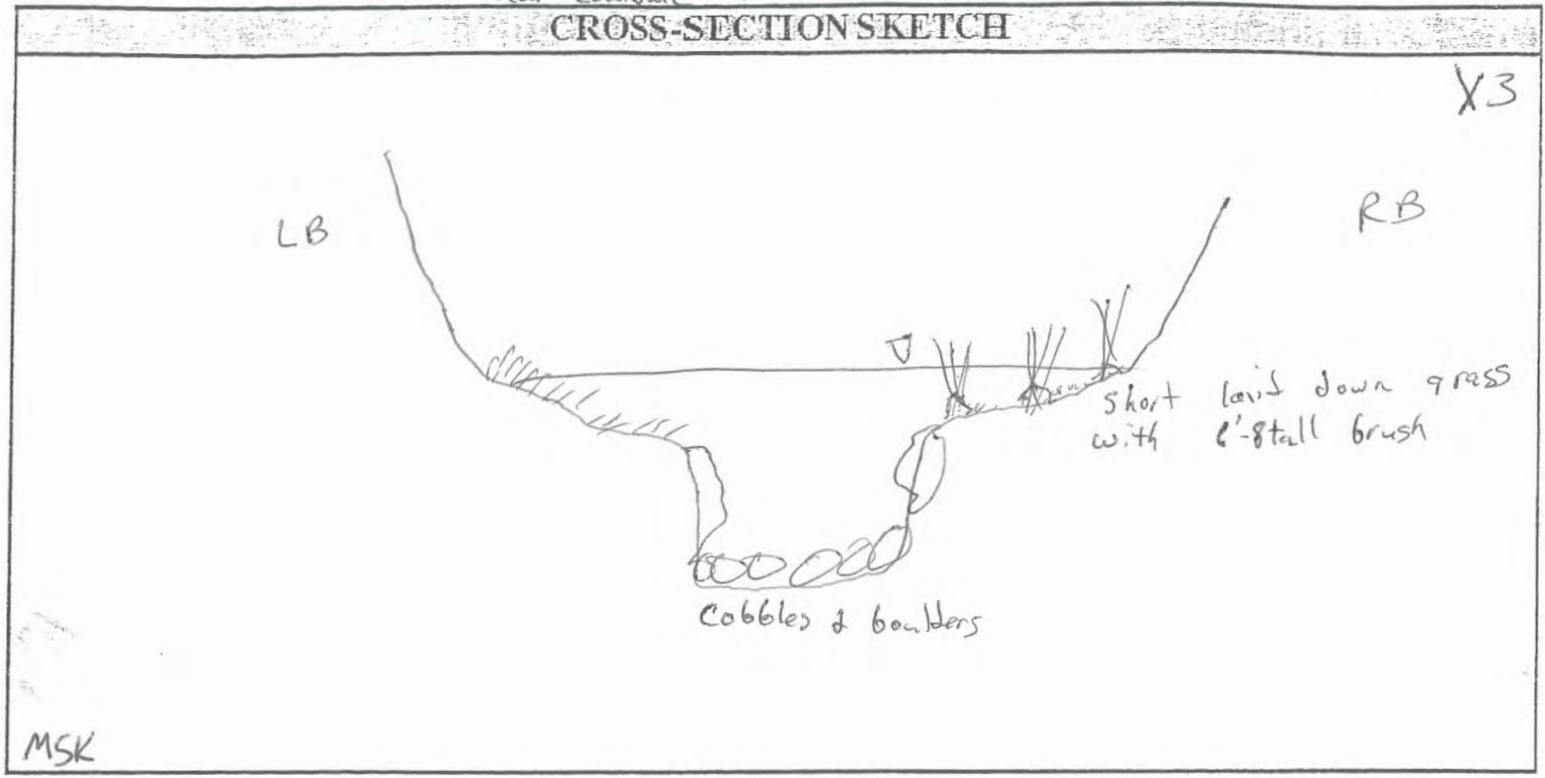

\begin{tabular}{|c|c|c|}
\hline 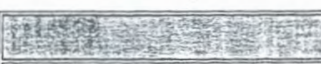 & \multicolumn{2}{|c|}{ Assign main channel roughness } \\
\hline Factor & Description & Roughness \\
\hline Base $(n 0)$ & Cobblos d boulders & 0.052 \\
\hline Irregularity (n1) & minos Channel irrecularity - Minor bank efoison & 0.004 \\
\hline Variability (n2) & frequeat changel variability due to qradient d Boulders & 0.010 \\
\hline Obstruction (n3) & mingr obstructions - debris piles on Grush & 0.010 \\
\hline Vegetation (n4) & Small vegetation - mostly small grassos loid down & 0.008 \\
\hline Meandering $(\mathrm{m})$ & minor &, 00 \\
\hline & Total $=$ & 0.084 \\
\hline
\end{tabular}

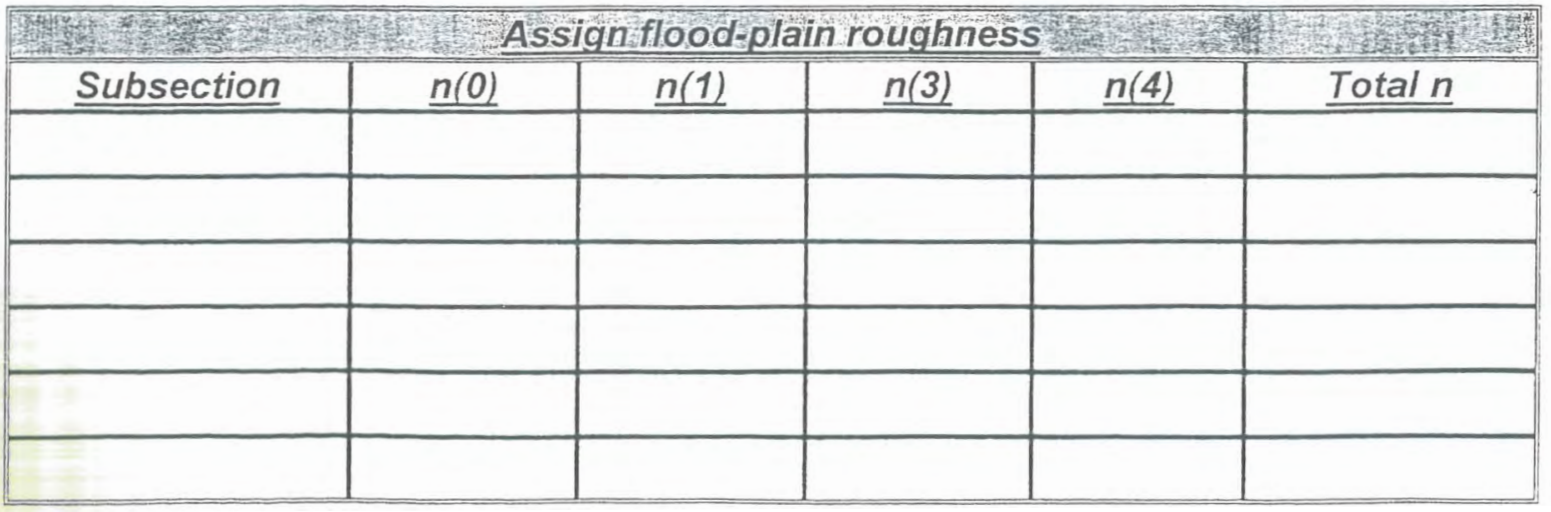

Figure 4-3. The Manning roughness coefficient ( $n$ ) assignment for cross section 3 on Big Cottonwood Creek at U.S. Highway 50 near Coaldale, Colorado. 


\section{Field Exercise - Roughness Assignment}

Site Name: Big Cutton woat creek at US-50 near Coablale; Date: $9.20-2016$

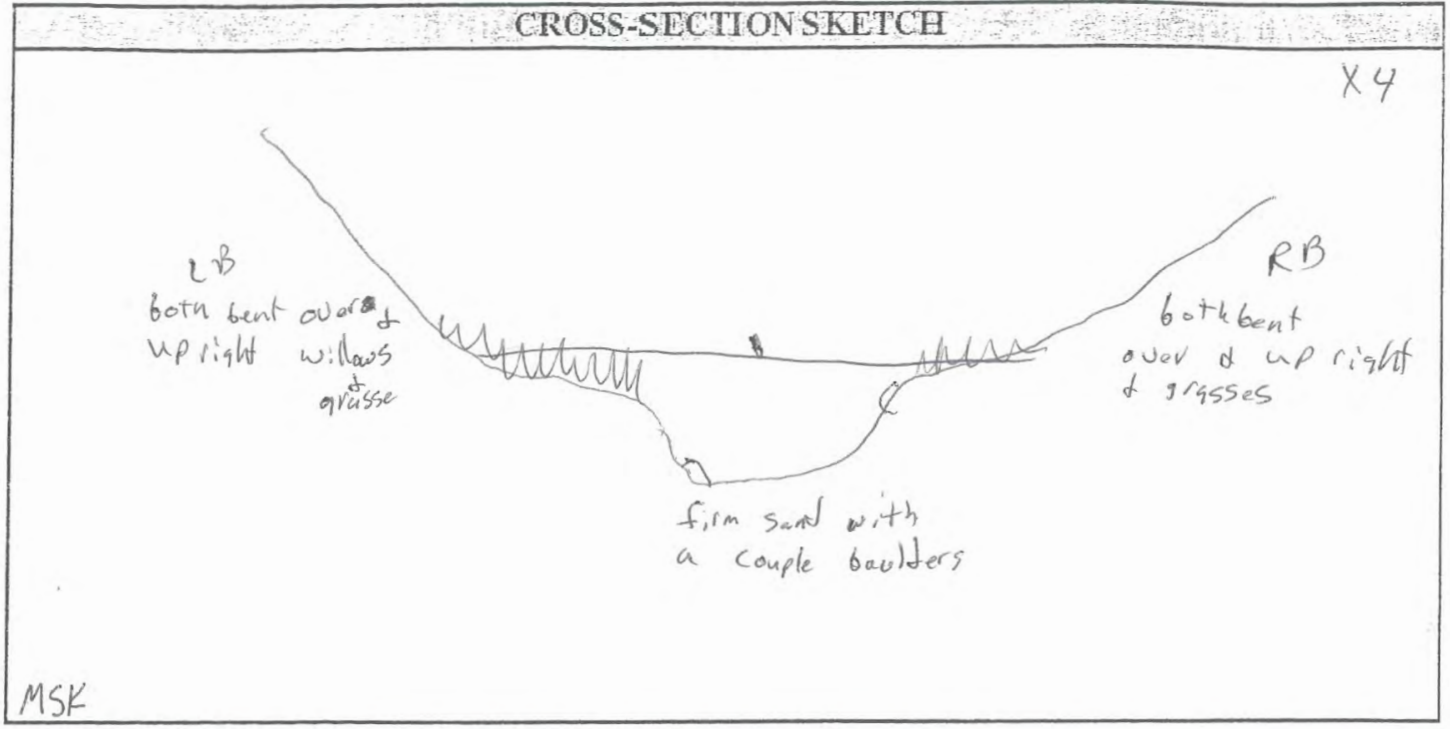

\begin{tabular}{|c|c|c|}
\hline Factor & Description & Roughness \\
\hline Base (no) & firm sund with a boulter occasionally & 0.050 \\
\hline Irregularity (n1) & very minor channel irreqularity & $0.00 \%$ \\
\hline Variability $(n 2)$ & minor cross section variability & 0.002 \\
\hline Obstruction (n3) & Some small tebris files at buse of cottonwoos & 0.010 \\
\hline Vegetation (n4) & willows I grass moderate to heavior density & 0.0201 \\
\hline Meandering $(\mathrm{m})$ & Minor & 1,00 \\
\hline & Total = & $0.08: 4$ \\
\hline
\end{tabular}

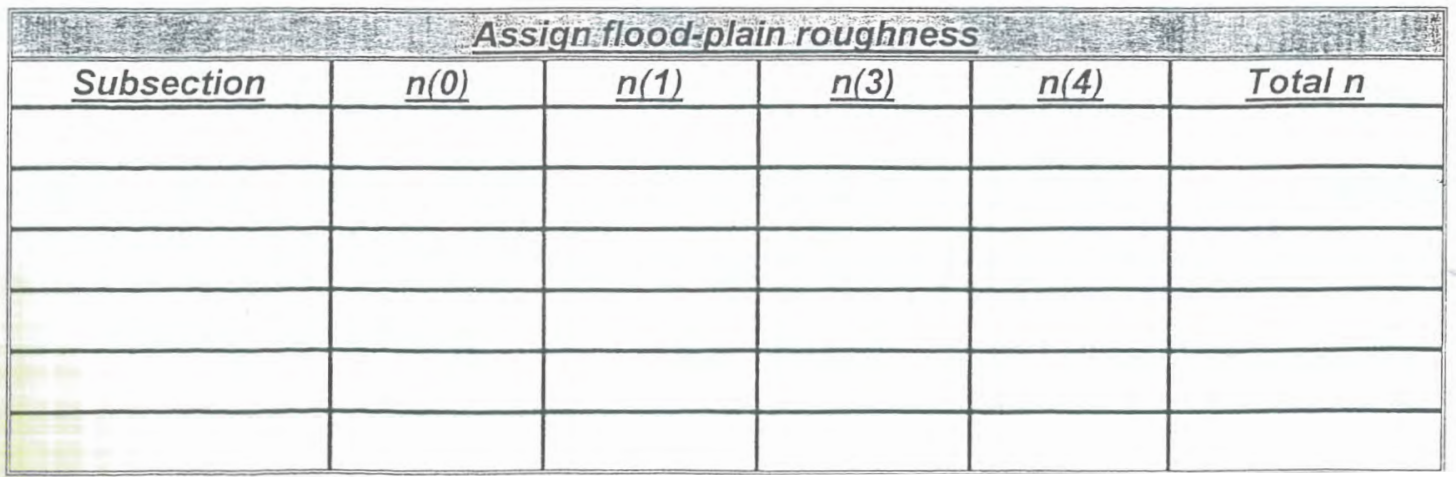

Figure 4-4. The Manning roughness coefficient (n) assignment for cross section 4 on Big Cottonwood Creek at U.S. Highway 50 near Coaldale, Colorado. 


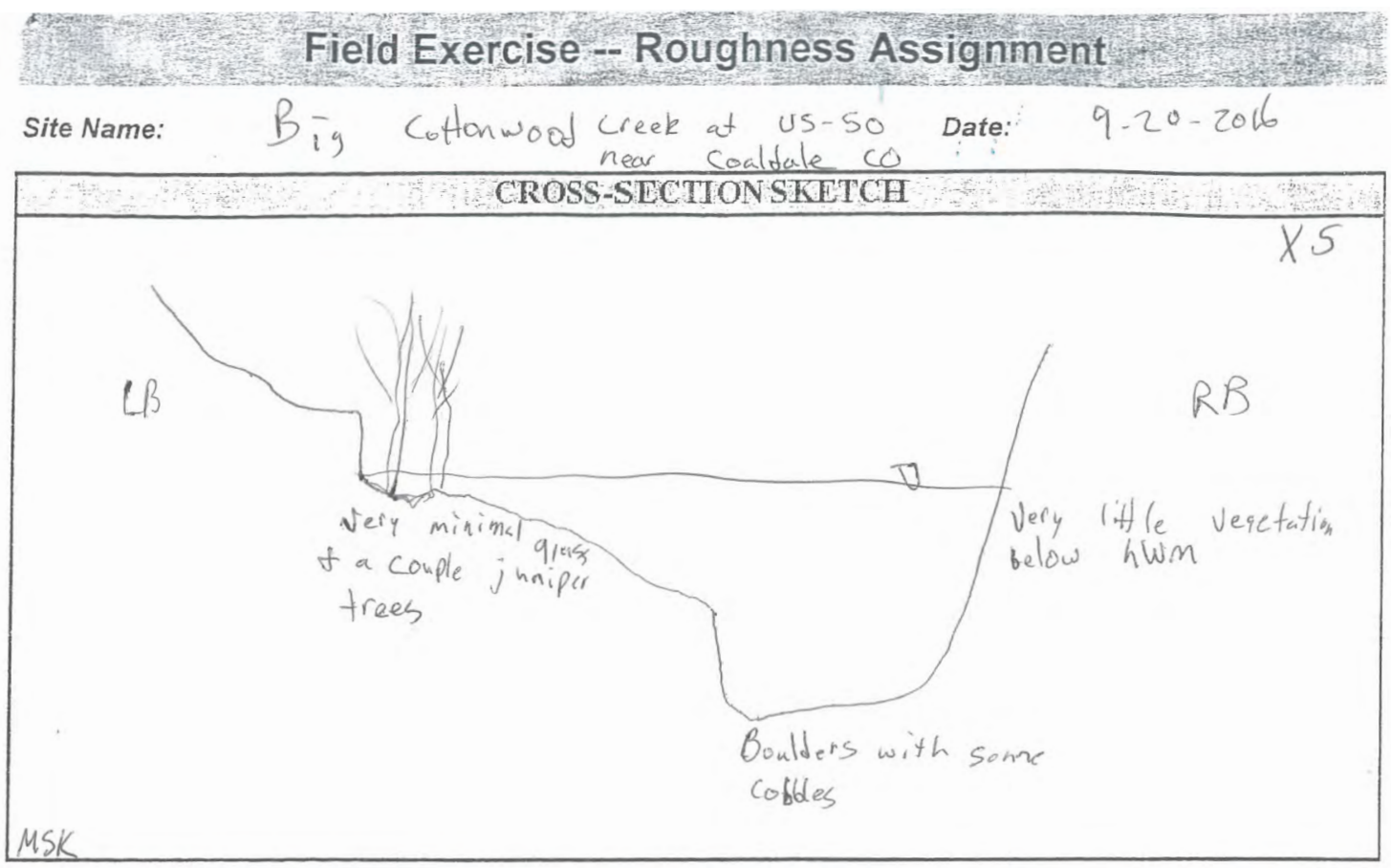

\begin{tabular}{|c|c|c|}
\hline 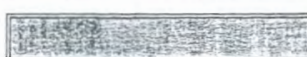 & Assign main-channel roughness & $\sqrt{19}$ \\
\hline Factor & Description & Roughness \\
\hline Base $(\mathrm{n} 0)$ & Boulder with Srme cobbles & 0,060 \\
\hline Irregularity (n1) & Minor channol irrecularidy-bunks scalloped & 0,005 \\
\hline Variability (n2) & Erequent chand vwiability tue to boulders & 0.010 \\
\hline Obstruction (n3) & obstruction & 0.005 \\
\hline Vegetation (n4) & grass bent over t a coude large iunipers & 0.008 \\
\hline Meandering (m) & Mingr & 1,00 \\
\hline & Total $=$ & 0.088 \\
\hline
\end{tabular}

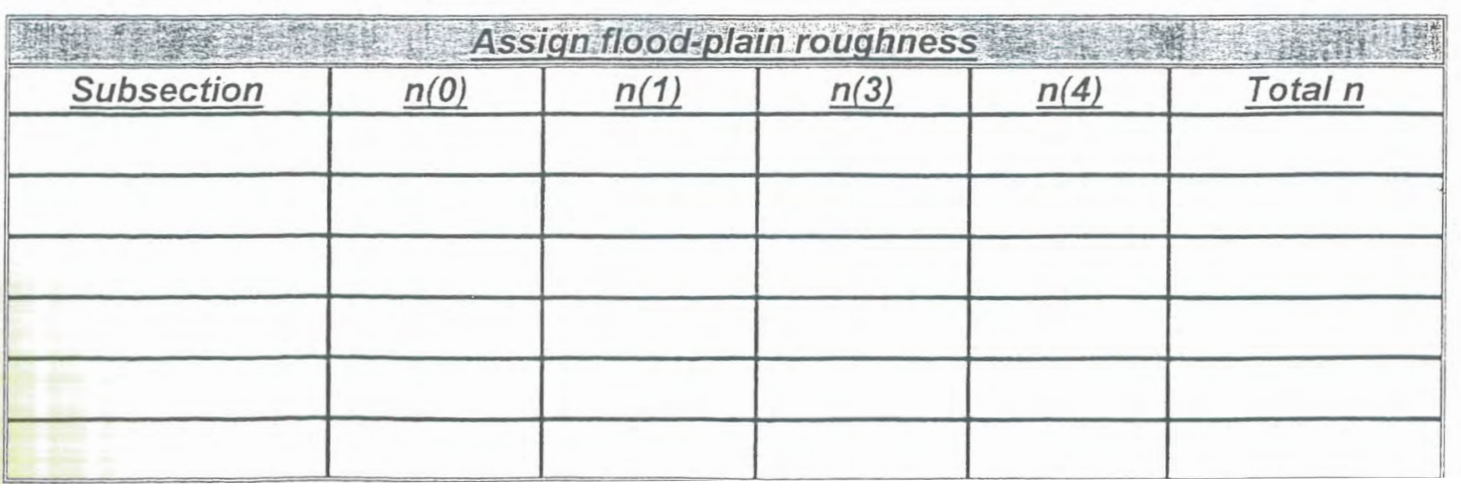

Figure 4-5. The Manning roughness coefficient ( $\mathrm{n}$ ) assignment for cross section 5 on Big Cottonwood Creek at U.S. Highway 50 near Coaldale, Colorado. 


\section{ROUGHNESS COEFFICIENTS$$
n=m(n 0+n 1+n 2+n 3+n 4)
$$

ASSIGN BASE ROUGHNESS (n0) VISUALIZE SIMPLE CHANNEL COMPOSED OF ONLY BED MATERIAL

\begin{tabular}{|c|c|c|c|}
\hline & & \multicolumn{2}{|c|}{ Base $n$ Value } \\
\hline Bed Material & $\begin{array}{l}\text { Median Size of bed material } \\
\text { (in millimeters) }\end{array}$ & Straight Uniform Channel & Smooth Channel \\
\hline \multicolumn{4}{|c|}{ Sand Channels } \\
\hline Sand $^{3}$ & $\begin{array}{l}0.2 \\
.3 \\
.4 \\
.5 \\
.6 \\
.8 \\
1.0\end{array}$ & $\begin{array}{l}0.012 \\
.017 \\
.020 \\
.022 \\
.023 \\
.025 \\
.026\end{array}$ & $\begin{array}{l}-- \\
-- \\
- \\
-- \\
-- \\
--\end{array}$ \\
\hline \multicolumn{4}{|c|}{ Stable Channels and Flood Plains } \\
\hline $\begin{array}{l}\text { Concrete } \\
\text { Rock Cut } \\
\text { Firm Soil } \\
\text { Coarse Sand } \\
\text { Fine Gravel } \\
\text { Gravel } \\
\text { Coarse Gravel } \\
\text { Cobble } \\
\text { Boulder }\end{array}$ & $\begin{array}{l}-- \\
-- \\
1-2 \\
-- \\
2-64 \\
- \\
64-256 \\
>256\end{array}$ & $\begin{array}{l}0.012-0.018 \\
= \\
0.025-0.032 \\
0.026-0.035 \\
= \\
0.028-0.035 \\
- \\
0.030-0.050 \\
0.040=0.070\end{array}$ & $\begin{array}{l}0.011 \\
.025 \\
.020 \\
. \\
.024 \\
. \\
.026 \\
. \\
-.\end{array}$ \\
\hline
\end{tabular}

ADJUST ROUGHNESS FOR CHANNEL IRREGULARITIES (n1)

\begin{tabular}{|l|l|l|}
\hline Channel Conditions & $n$ Value Adjustment & \multicolumn{1}{c|}{ Example } \\
\hline Degres of lregularity $\left(n_{1}\right)$ & 0.000 & $\begin{array}{l}\text { Compares to the smoothest channel attainable in a given bed } \\
\text { material. }\end{array}$ \\
\hline Smooth & $0.001-0.005$ & $\begin{array}{l}\text { Compares to carefully degraded channels in good condition but } \\
\text { having slightly eroded or scoured side slopes. }\end{array}$ \\
\hline Moderate & $\begin{array}{l}\text { Compares to dredged channels having moderate to } \\
\text { considerable bed roughness and moderately sloughed or } \\
\text { eroded side slopes. } \\
\text { s in rock. }\end{array}$ \\
\hline Severe & $\begin{array}{l}\text { Badly sloughed or scalloped banks of natural streams; badly } \\
\text { eroded or sloughed sides of canals or drainage channels; } \\
\text { unshaped, jagged, and irregular surfaces of channel }\end{array}$ \\
\hline
\end{tabular}

ADJUST ROUGHNESS FOR CROSS-SECTIONAL VARIATIONS (n2)

\begin{tabular}{|l|l|l|}
\hline Channel Conditions & $n$ Value Adjustment & \multicolumn{1}{c|}{ Example } \\
\hline Gradual & 0.000 & Size and shape of channel cross sections change gradually. \\
\hline Alternating occasionally & $0.001-0.005$ & $\begin{array}{l}\text { Large and small cross sections alternate occasionally, or the } \\
\text { main flow occasionally shifts from side to side owing to } \\
\text { changes in cross-sectional shape. }\end{array}$ \\
\hline Alternating frequently & $0.010-0.015$ & $\begin{array}{l}\text { Large and small cross sections alternate frequently, or } \\
\text { the main flow frequently shifts from side to side owing } \\
\text { to changes in cross-sectional shape. }\end{array}$ \\
\hline
\end{tabular}

Figure 4-6. The Manning roughness coefficient (n) assignment worksheet using the Cowan method, page 1 (Cowan, 1956). 
ADJUST ROUGHNESS FOR OBSTRUCTIONS ( $n 3$ )

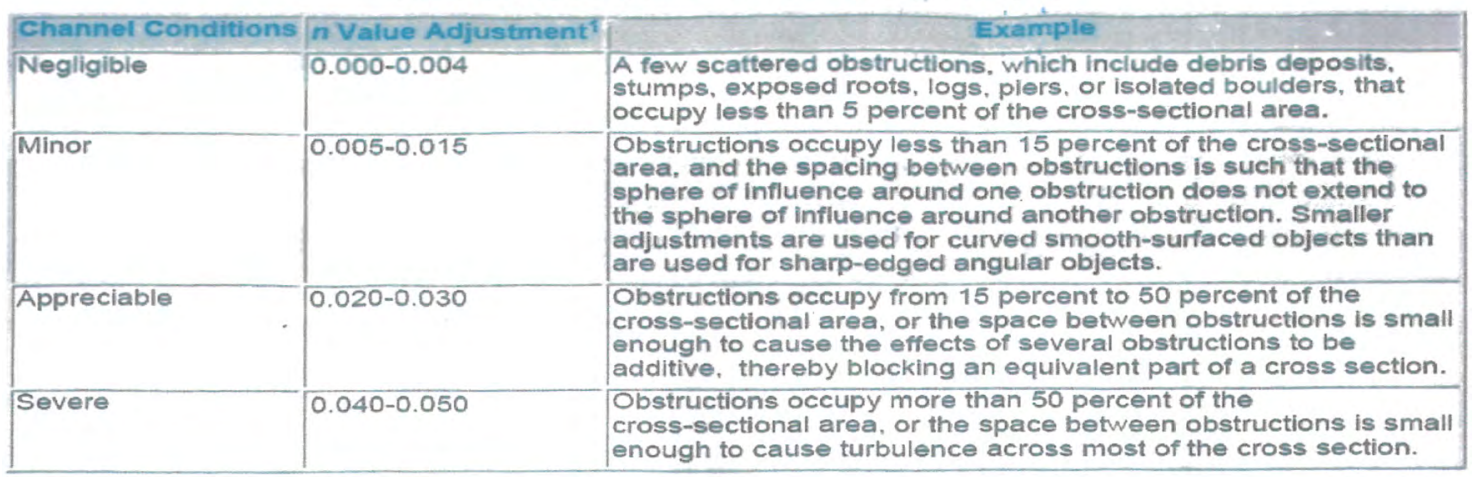

ADJUST ROUGHNESS FOR VEGETATION (n4)

\begin{tabular}{|c|c|c|}
\hline Channel Conditions & n Value Adjustment & Example \\
\hline Small & $0.002-0.010$ & $\begin{array}{l}\text { Dense growths of flexible turf grass, such as Bermuda, or } \\
\text { weeds growing where the average depth of flow is at least two } \\
\text { times the height of the vegetation; supple tree seedlings such } \\
\text { as willow, cottonwood, arrowhead, or saltcedar growing where } \\
\text { the average depth of flow is at least three times the height of the } \\
\text { vegetation. }\end{array}$ \\
\hline Medium & $0.010-0.025$ & $\begin{array}{l}\text { Turf grass growing where the average depth of flow is from one } \\
\text { to two times the height of the vegetation; moderately dense } \\
\text { stemy grass, weeds, or tree seedlings growing where the } \\
\text { average depth of flow is from two to three times the height of } \\
\text { the vegetation; brushy, moderately dense vegetation, similar to } \\
1 \text {-to-2-year-old willow trees in the dormant season, growing } \\
\text { along the banks, and no significant vegetation is evident along } \\
\text { the channel bottoms where the hydraulic radius exceeds } 0.61 \\
\text { meters. }\end{array}$ \\
\hline Large & $0.025-0.050$ & $\begin{array}{l}\text { Turf grass growing where the average depth of flow is about } \\
\text { equal to the height of the vegetation; } 8 \text {-to-10-years-old willow or } \\
\text { cottonwood trees intergrown with some weeds and brush (none } \\
\text { of the vegetation in foliage) where the hydraulic radius } \\
\text { exceeds0.60 m; bushy willows about } 1 \text { year old intergrown with } \\
\text { some weeds along side slopes (all vegetation in full foliage), } \\
\text { and no significant vegetation exists along channel bottoms } \\
\text { where the hydraulic radius is greater than } 0.61 \text { meters. }\end{array}$ \\
\hline Very Large & $0.050-0.100$ & $\begin{array}{l}\text { Turf grass growing where the average depth of flow is less than } \\
\text { half the height of the vegetation; bushy willow trees about } 1 \\
\text { year old intergrown with weeds along side slopes } C \text { all } \\
\text { vegetation in full foliage), or dense cattails growing } \\
\text { along channel bottom; trees intergrow with weeds and brush } \\
\text { (all vegetation in full follage). }\end{array}$ \\
\hline
\end{tabular}

ADJUST ROUGHNESS FOR MEANDERING $(m)$

\begin{tabular}{|c|c|c|}
\hline Channel Conditions & n Value Adjustment & Example \\
\hline Minor & 1.00 & $\begin{array}{l}\text { Ratio of the channel length } \\
\text { to valley length is } 1.0 \text { to } 1.2 \text {. }\end{array}$ \\
\hline Appreciable & 1.15 & $\begin{array}{l}\text { Ratio of the channel length } \\
\text { to valley length is } 1.2 \text { to } 1.5 \text {. }\end{array}$ \\
\hline Severe & 1.30 & $\begin{array}{l}\text { Ratio of the channel length } \\
\text { to valley length is greater } \\
\text { than } 1.5 \text {. }\end{array}$ \\
\hline
\end{tabular}

Figure 4-7. The Manning roughness coefficient (n) assignment worksheet using the Cowan method, page 2 (Cowan, 1956). 
Appendix 5. Plots Showing the Cross Sections with Manning Roughness Coefficients (n) Assignments for Big Cottonwood Creek at U.S. Highway 50 near Coaldale, Colorado Photos available @ https://doi.org/10.3133/sir20175107 


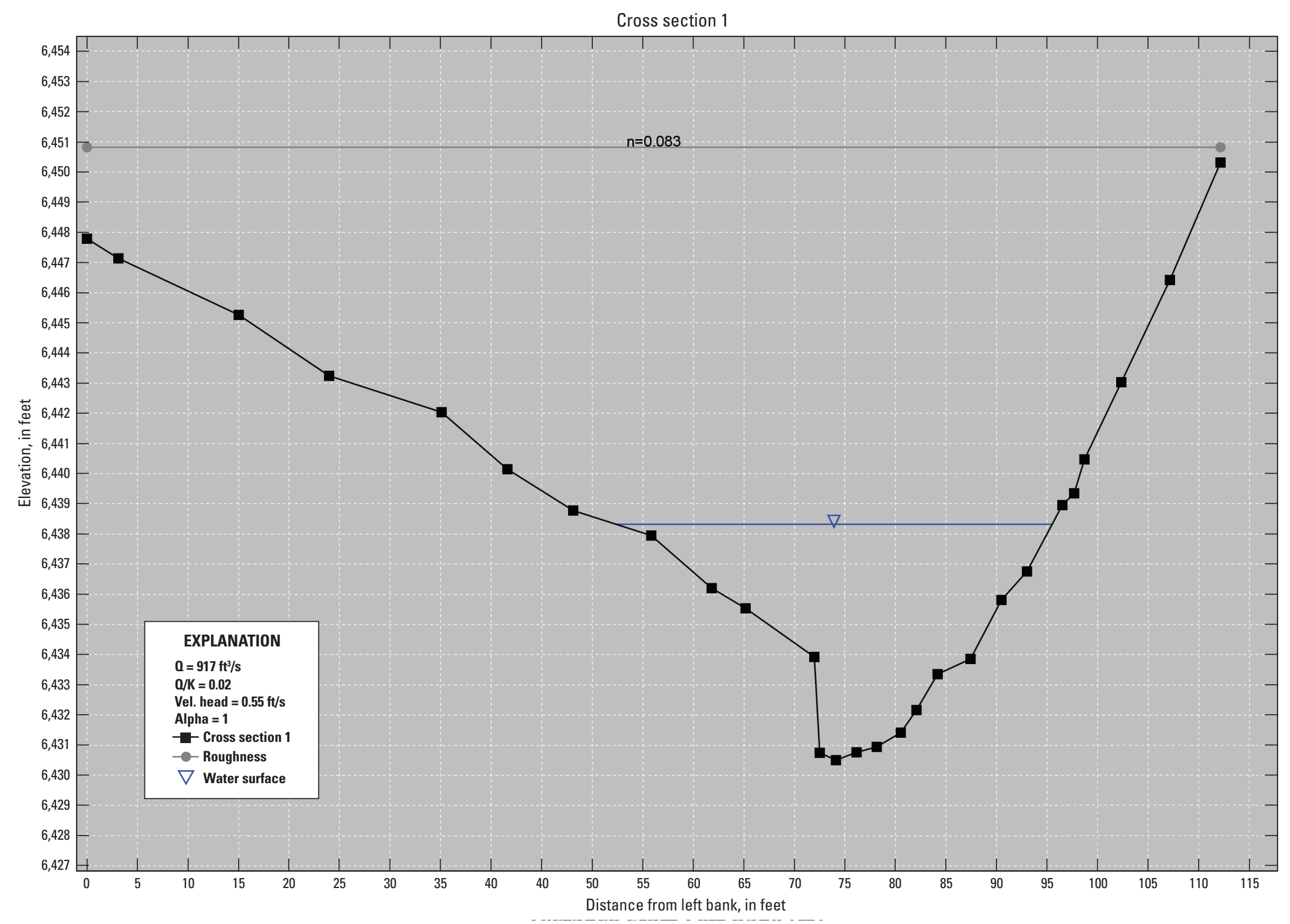

Figure 5-1. Cross section 1 with the Manning roughness coefficient (n) assignment for Big Cottonwood Creek at U.S. Highway 50 near Coaldale, Colorado; generated from the Slope-Area Computation Graphical User Interface. [X1, cross section 1; 0 , discharge; f $\mathrm{t}^{3} \mathrm{~s}$, cubic foot per second; $\mathrm{K}$, conveyance; Vel., velocity; ft/s, foot per second] 


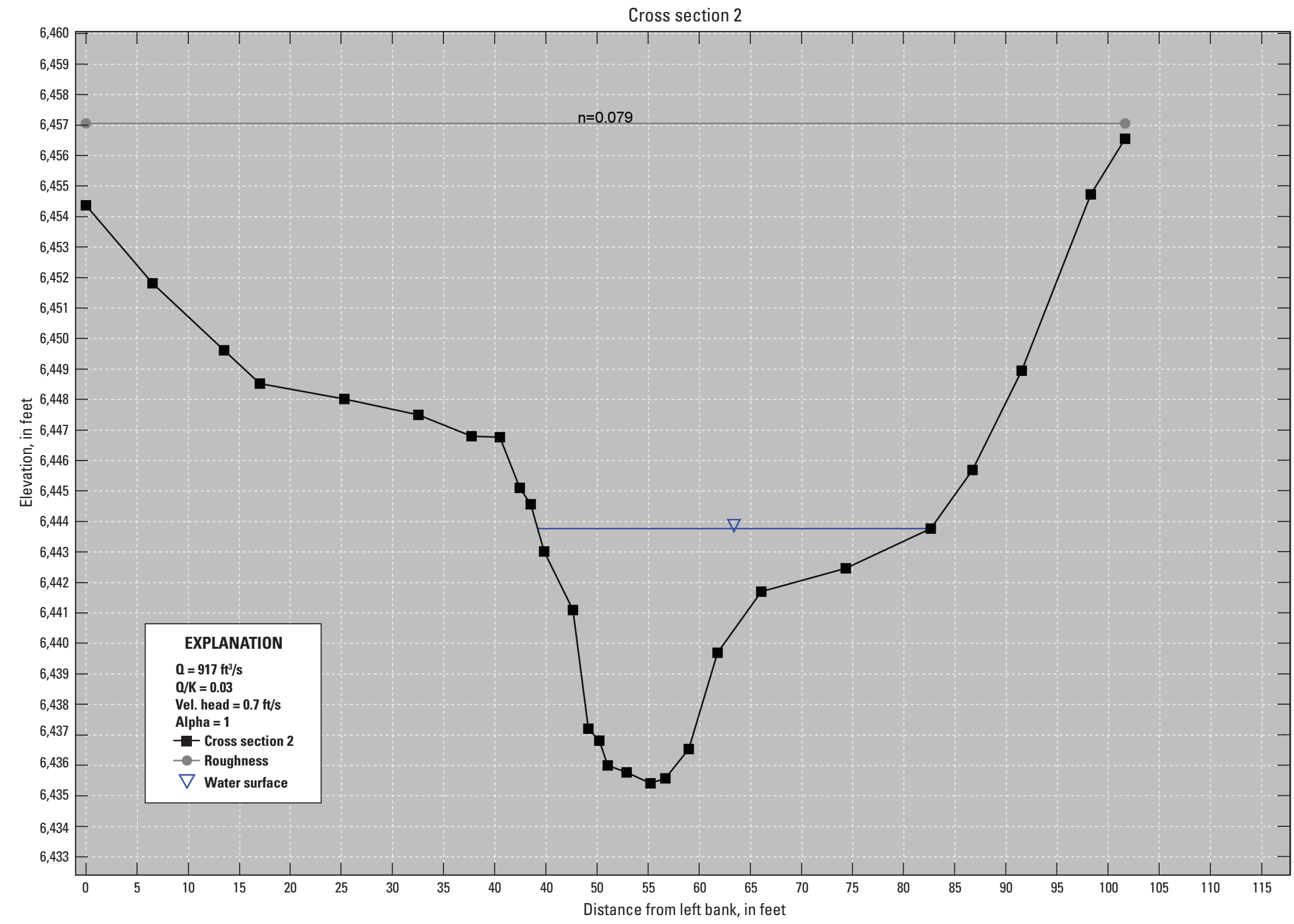

Figure 5-2. Cross section 2 with the Manning roughness coefficient (n) assignment for Big Cottonwood Creek at U.S. Highway 50 near Coaldale, Colorado; generated from the Slope-Area Computation Graphical User Interface. [X2, cross section 2; $\mathrm{Q}$, discharge; $\mathrm{ft}^{3} / \mathrm{s}$, cubic foot per second; $\mathrm{K}$, conveyance; Vel., velocity; ft/s, foot per second] 


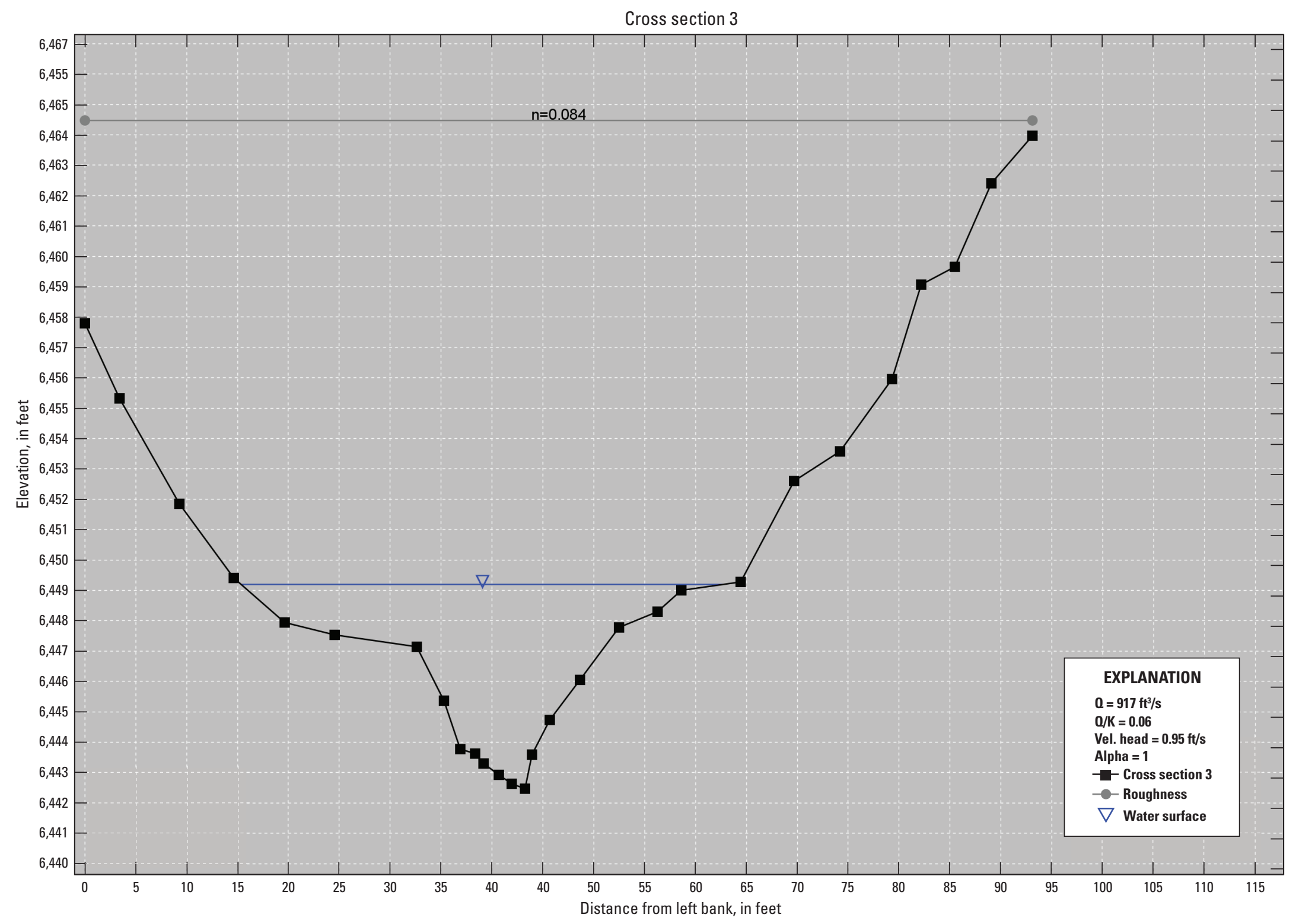

Figure 5-3. Cross section 3 with the Manning roughness coefficient ( $\mathrm{n}$ ) assignment for Big Cottonwood Creek at U.S. Highway 50 near Coaldale, Colorado; generated from the Slope-Area Computation Graphical User Interface. [X3, cross section 3; 0, discharge; $\mathrm{ft}^{3} / \mathrm{s}$, cubic foot per second; $\mathrm{K}$, conveyance; Vel., velocity; ft/s, foot per second] 
Cross section 4

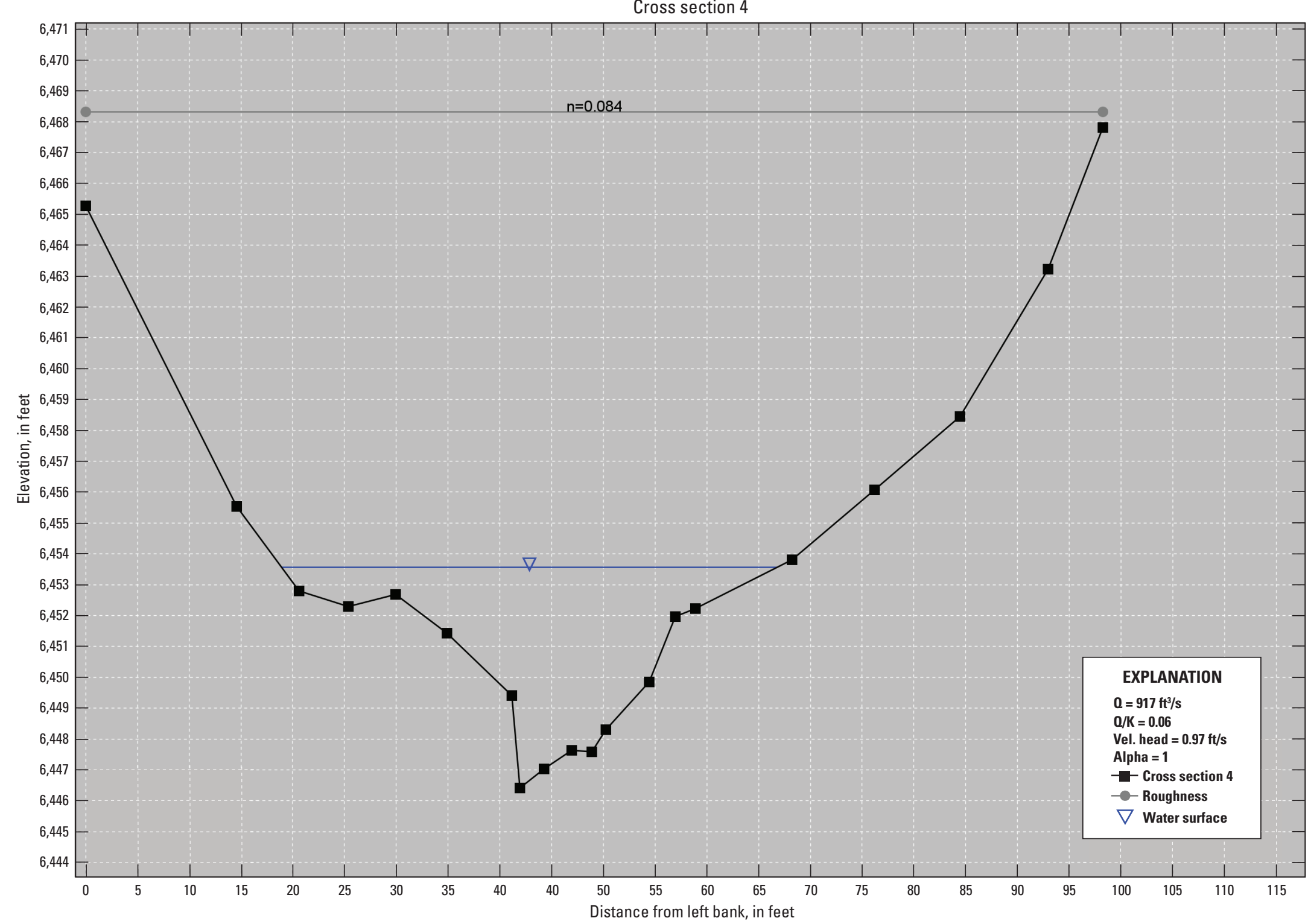

Figure 5-4. Cross section 4 with the Manning roughness coefficient (n) assignment for Big Cottonwood Creek at U.S. Highway 50 near Coaldale, Colorado generated from the Slope-Area Computation Graphical User Interface. [X4, cross section 4; 0, discharge; $\mathrm{ft}^{3} / \mathrm{s}$, cubic foot per second; K, conveyance; Vel., velocity; ft/s, foot per second] 


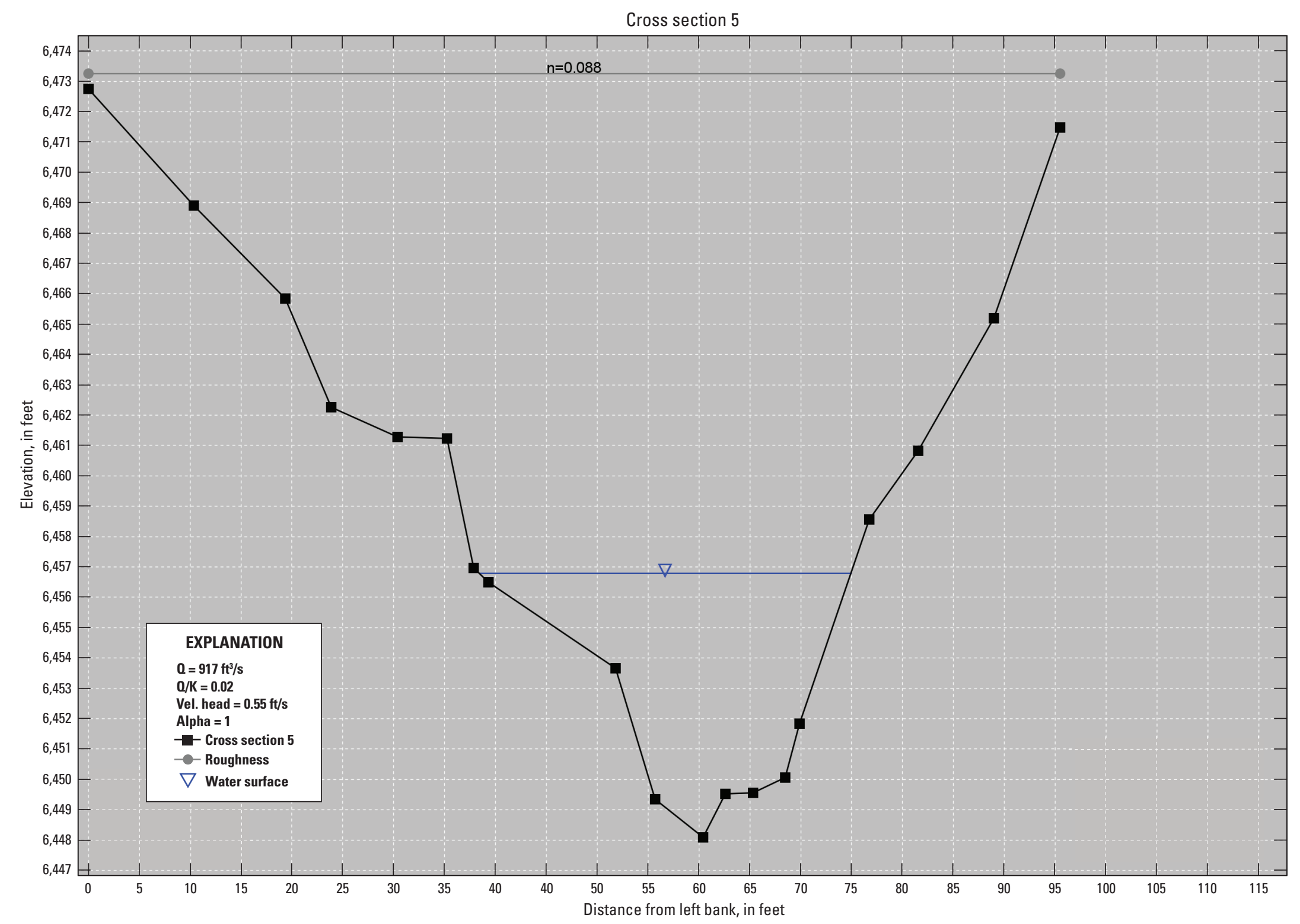

Figure 5-5. Cross section 5 with the Manning roughness coefficient ( $\mathrm{n}$ ) assignment for Big Cottonwood Creek at U.S. Highway 50 near Coaldale, Colorado; generated from the Slope-Area Computation Graphical User Interface. [X5, cross section 5; 0 , discharge; $\mathrm{ft}^{3} / \mathrm{s}$, cubic foot per second; K, conveyance; Vel., velocity; ft/s, foot per second] 
Appendix 6. Survey Field Notes from Fountain Creek below U.S. Highway 24 in Colorado Springs,

Colorado

\begin{tabular}{|c|c|c|c|c|c|c|c|c|}
\hline \multicolumn{2}{|c|}{ Location Description: } & 07105530 & Fountain & & \multicolumn{2}{|c|}{ BWW Colardo spings CO } & \multirow[t]{2}{*}{ page 1 of 1} \\
\hline Coordinate Sys.: & \multicolumn{2}{|l|}{ UTM (13 North) } & Units: & \multicolumn{2}{|c|}{ Us gurvey Feet / Meters } & Date of Survey: & $9 / 21 / 2016$ & \\
\hline Datum: & \multicolumn{2}{|l|}{ NAD 1983 (2011) (7P) } & Geoid Model: & \multirow{2}{*}{\multicolumn{2}{|c|}{$\begin{array}{l}\text { GEOID } 2012 \mathrm{~A} \\
\text { OPUS Base location }\end{array}$}} & Survey Party: & \multirow{2}{*}{\multicolumn{2}{|c|}{ MSK/MRS/IGV/ELR/WEP }} \\
\hline \multicolumn{4}{|l|}{ - } & & & & & \\
\hline Time & Base Filename & Base Point Name & Northing & Easting & Elevation & Latitude & Longitude & Ellipsoid Height \\
\hline $095 i$ & 22762650 & BASE & & & & & & + \\
\hline Equipment & Serial Number & Contoller Name & Operator/Setup By & Job Name & Starting Pt Name & Antenna Height & & \\
\hline Radio & 12489653 & & MSK & & & & Measured to: & Checked with tape \\
\hline R8 Base & 4638122276 & $\operatorname{cossc} \# 3$ & $M S K$ & 67105530 & & 1.015 & Mid Bumper / Base & (v) $/ \mathrm{N}$ \\
\hline R8 Receiver 1 & 5242498441 & 11 & MSK & ii & MSKI & $2.000 \mathrm{~m}$ & Mid Bumper / Besse & $Y, \mathbb{Q}$ \\
\hline R8 Receiver 2 & 4638122169 & cusc $\#$ & MSK & $07105530-$ MRS & MRSO01 & $2.000 \mathrm{~m}$ & Mid Bumper / Basse & Y 10 \\
\hline R8 Receiver 3 & & & & & & & Mid Bumper / Base & $\mathrm{Y} / \mathrm{N}$ \\
\hline R8 Receiver 4 & & & & & & & Mid Bumper / Base & $\mathrm{Y} / \mathrm{N}$ \\
\hline R8 Receiver 5 & & & & & & & Mid Bumper / Base & $\mathrm{Y} / \mathrm{N}$ \\
\hline R8 Receiver 6 & & & & & & & Mid Bumper / Base & Y I N \\
\hline \multicolumn{9}{|c|}{ Control Point Summary } \\
\hline Control Point & Reciever \# & Contoller Name & Point Name & Code & Date/Time & \multicolumn{3}{|c|}{ Additional Information } \\
\hline b & BASE & $\operatorname{cosc} \# 3$ & BASE & $\begin{array}{l}\text { REAAR IN } \\
\text { CONKRETE } \\
\text { BARRIER } \\
\end{array}$ & 0951 & \multicolumn{3}{|c|}{ STATION } \\
\hline RM 10 & 1 & cuse \#3 & MSK1 & RMIO-START & & \multicolumn{3}{|c|}{ CHECK IN } \\
\hline RM 10 & 1 & cusc $\# 3$ & 16059 & RMIO-END & & \multicolumn{3}{|c|}{ CHECK OUT } \\
\hline & & & & & & & & \\
\hline & & & & & & & & \\
\hline & & & & & & & & \\
\hline & & & & & & & & \\
\hline & & & & & & & & \\
\hline & & & & & & & & \\
\hline & & & & & & & & \\
\hline
\end{tabular}

Figure 6-1. The field notes from the September 21, 2016, survey for Fountain Creek below U.S. Highway 24 in Colorado Springs, Colorado. 
Appendix 7. Photos of High-Water Marks from Fountain Creek below U.S. Highway 24 in Colorado Springs, Colorado Photos available @ https://doi.org/10.3133/sir20175107 


\section{Appendix 8. Photos of Cross Sections from Fountain Creek below U.S.}

Highway 24 in Colorado Springs, Colorado Photos available @ https://doi.org/10.3133/sir20175107 


\section{Appendix 9. Manning Roughness Coefficient (n) Assignments and Channel Conditions for the Cross Sections on Fountain Creek below U.S. Highway 24 in Colorado Springs, Colorado}

\section{Field Exercise - Roughness Assignment}

Site Name: Fountain Creek Janitell Ad CoSprgs Date: 9-21- 2016

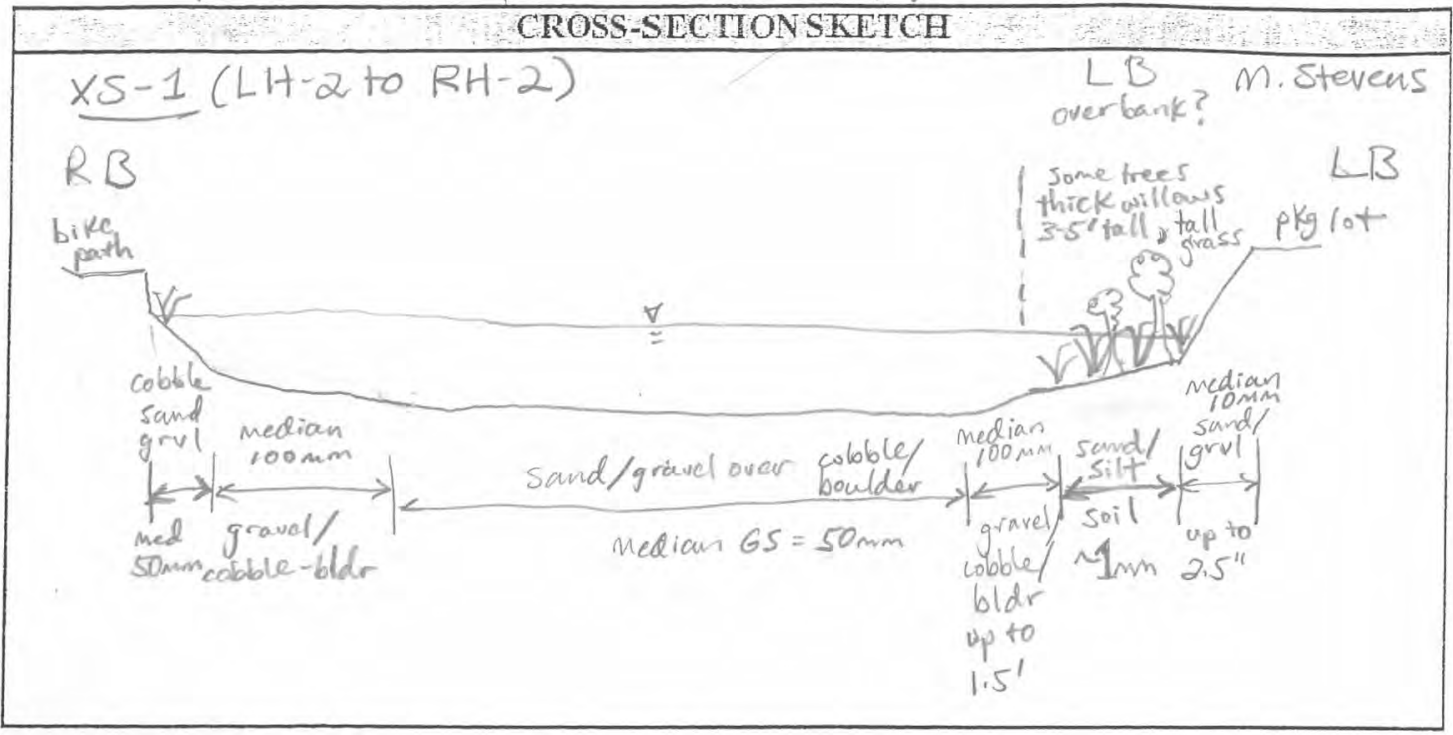

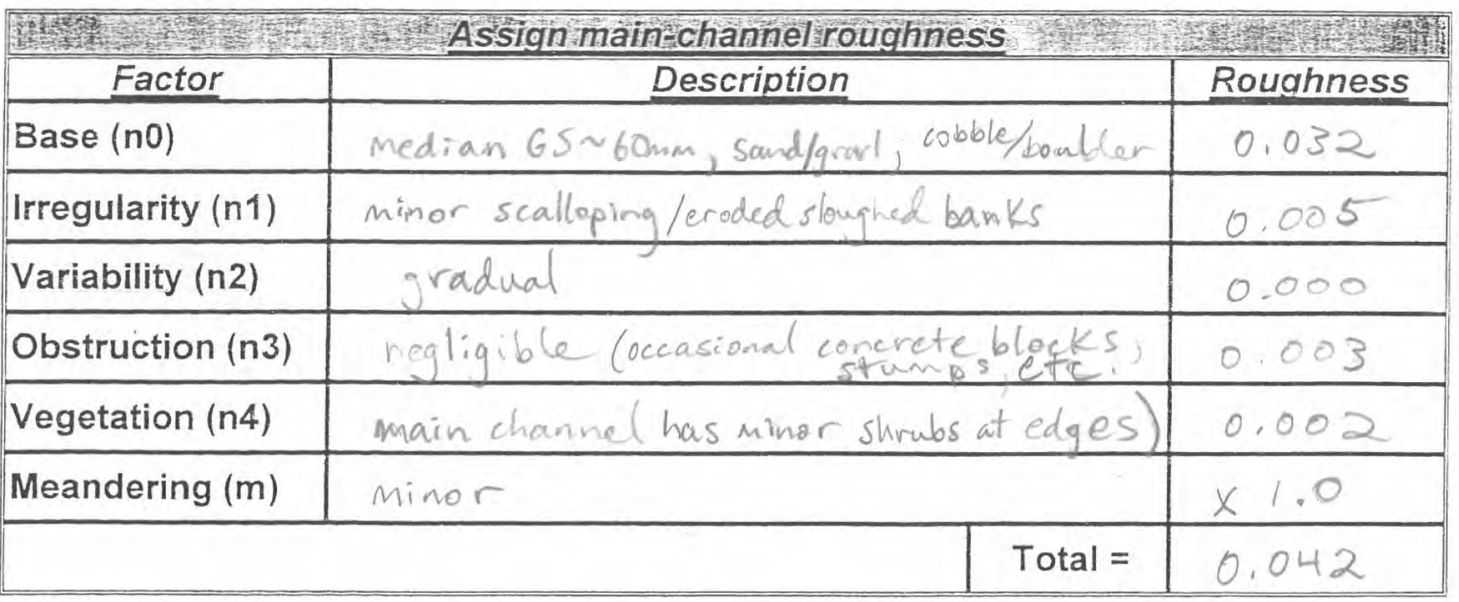

\begin{tabular}{|l|c|c|c|c|c|}
\hline \multicolumn{7}{|c|}{ Assign flood-plain roughness } \\
\hline \hline Subsection & $\underline{n(0)}$ & $\underline{n(1)}$ & $\underline{n(3)}$ & $\underline{n(4)}$ & $\underline{\text { Total } n}$ \\
\hline LB & 0.025 & 0.006 & 0.010 & 0.030 & 0.062 \\
\hline & & & & & \\
\hline & & & & & \\
\hline & & & & & \\
\hline & & & & & \\
\hline
\end{tabular}

Figure 9-1. The Manning roughness coefficient (n) assignments for cross section 1 on Fountain Creek below U.S. Highway 24 in Colorado Springs, Colorado. 


\section{Field Exercise - Roughness Assignment}

Site Name: Fountain Cr Janitell Rd, cosprgs Date: 9-21-2016

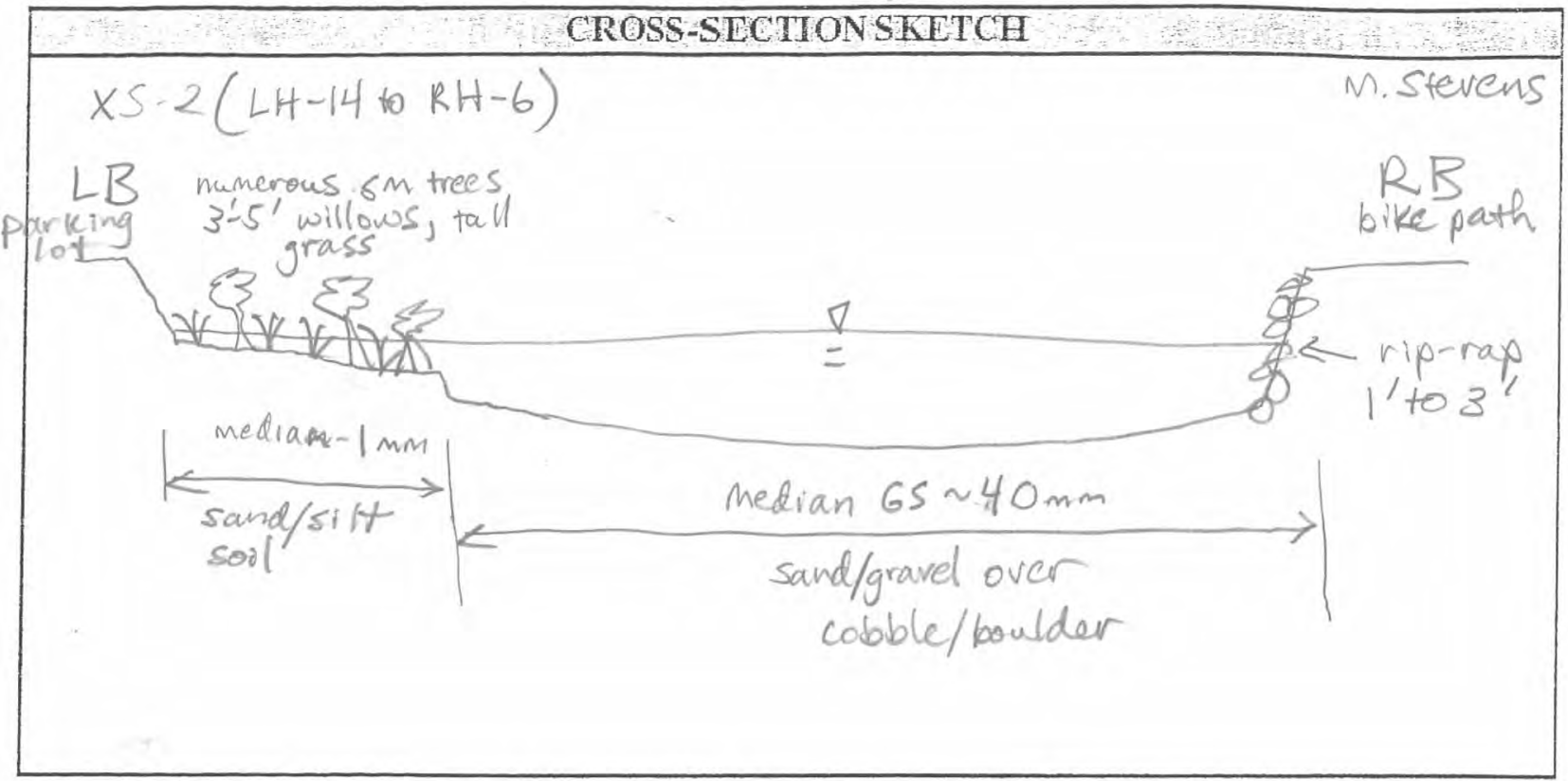

\begin{tabular}{|c|c|c|}
\hline \multicolumn{2}{|c|}{ 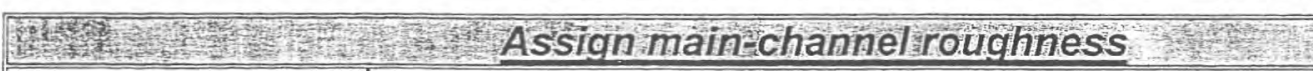 } & \multirow{2}{*}{ Rouahness } \\
\hline Factor & Description & \\
\hline Base $(\mathrm{n} 0)$ & median G.S. $\sim 40 \mathrm{~mm}$, sand/grul over cobble/ & 0.028 \\
\hline Irregularity (n1) & moderate scalloping /eroded banks & 0.010 \\
\hline Variability (n2) & gradual & 0.000 \\
\hline Obstruction (n3) & negligible (occasional concrete blocks, & 0.004 \\
\hline Vegetation (n4) & main channel: (20\% grass/weeds, some trees) & 0.004 \\
\hline Meandering $(\mathrm{m})$ & minor & $\times 1.0$ \\
\hline & Total $=$ & 0.046 \\
\hline
\end{tabular}

\begin{tabular}{|c|c|c|c|c|c|}
\hline 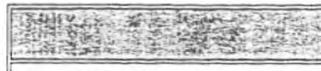 & Fis & flood & roughi & (1) & 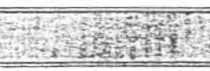 \\
\hline Subsection & $\underline{n(0)}$ & $n(1)$ & $n(3)$ & $n(4)$ & Total $n$ \\
\hline$\angle B$ & 0.025 & 0.006 & 0,010 & 0.030 & 0.062 \\
\hline & & & & & \\
\hline & & & & & \\
\hline & & & & & \\
\hline & & & & & \\
\hline & & & & & \\
\hline
\end{tabular}

Figure 9-2. The Manning roughness coefficient (n) assignments for cross section 2 on Fountain Creek below U.S. Highway 24 in Colorado Springs, Colorado. 


\section{Field Exercise - Roughness Assignment}

Site Name: Fountain Cr Janitell Rd, CO Sprgs Date: $9-21-2016$

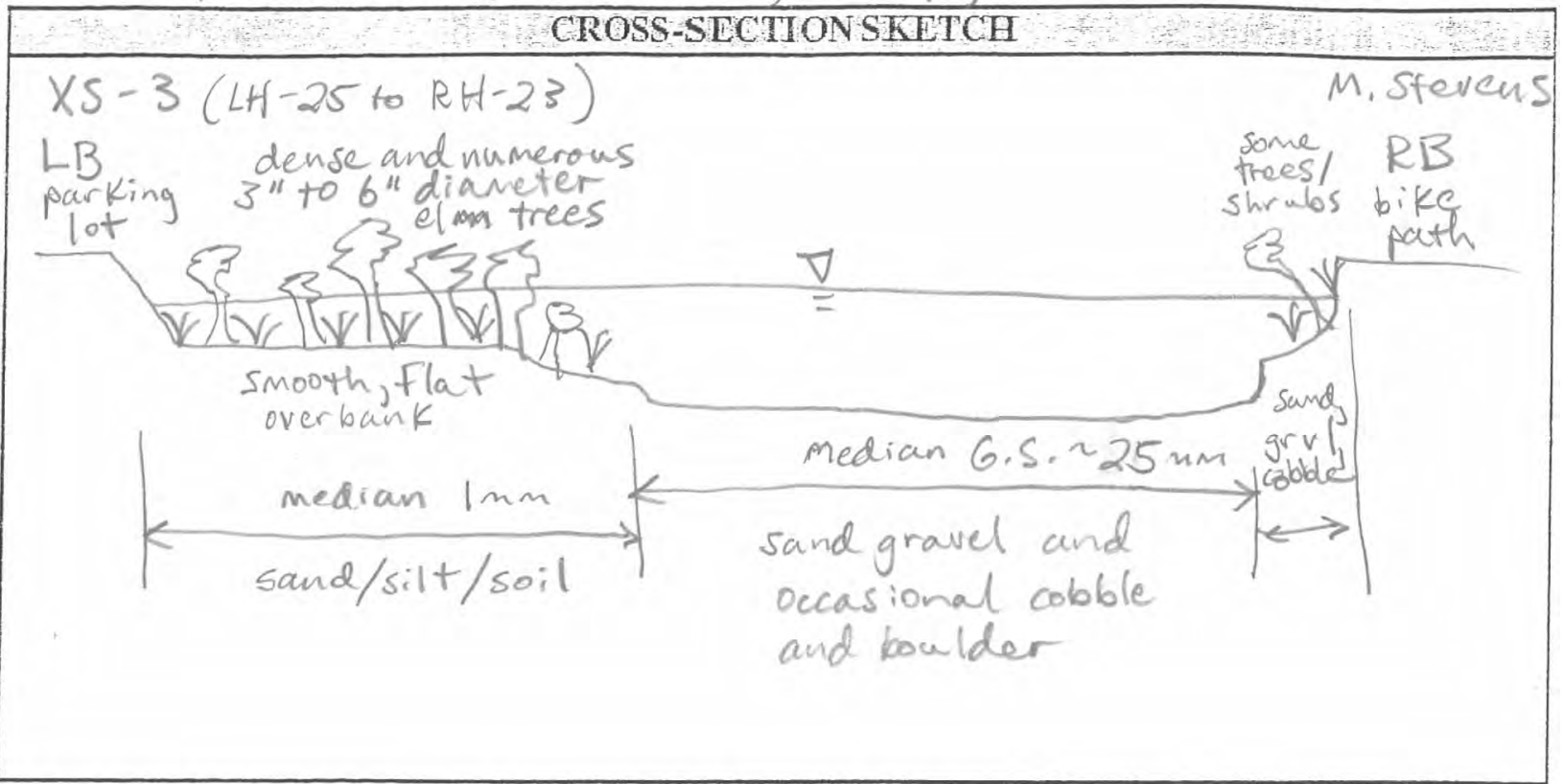

\begin{tabular}{|c|c|c|}
\hline 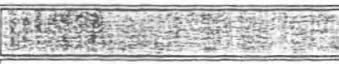 & Nef Assign main channel roughness & 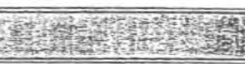 \\
\hline Factor & Description & Roughness \\
\hline Base $(\mathrm{n} 0)$ & Median 6.5. $25 \mathrm{~mm}$, sand/gravel & 0.026 \\
\hline Irregularity (n1) & minor scalloping/eroded banks & 0.008 \\
\hline Variability (n2) & gradual & 0.000 \\
\hline Obstruction (n3) & negligible stumps, concrete block's & 0.002 \\
\hline Vegetation (n4) & main channe( $20 \%$ shrubs/tall grass & 0.004 \\
\hline Meandering $(\mathrm{m})$ & Minor & $x 1.0$ \\
\hline & Total $=$ & 0.040 \\
\hline
\end{tabular}

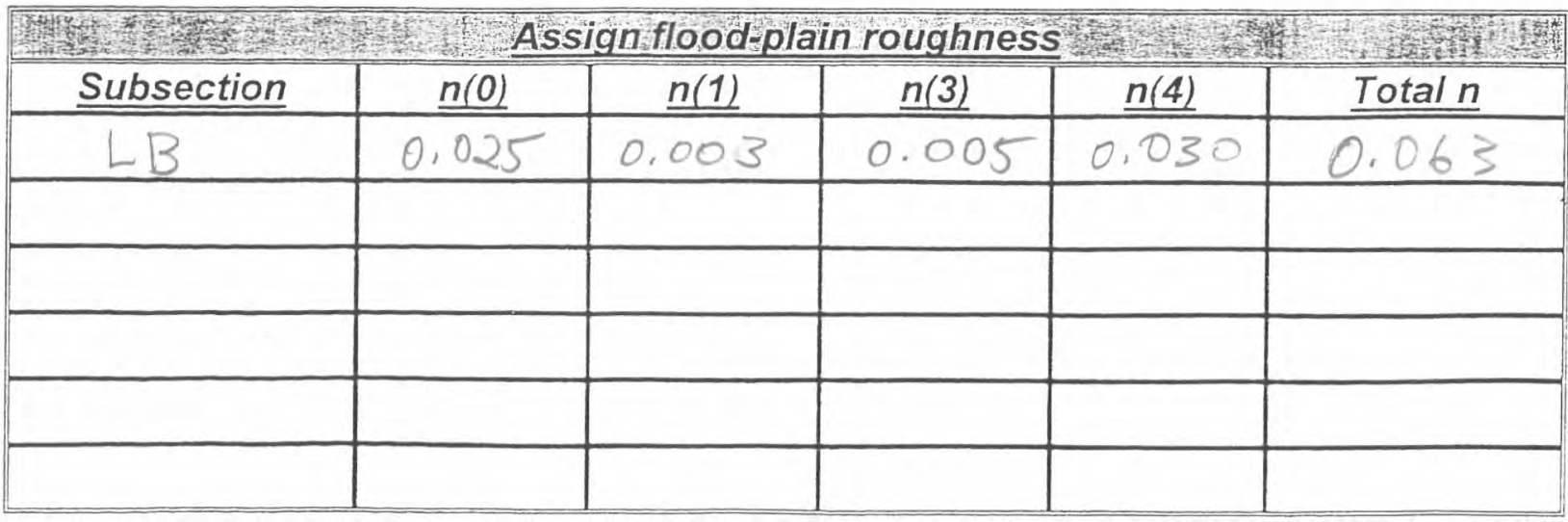

Figure 9-3. The Manning roughness coefficient (n) assignments for cross section 3 on Fountain Creek below U.S. Highway 24 in Colorado Springs, Colorado. 


\section{Field Exercise - Roughness Assignment}

Site Name: Fountain Cr Janitell Rd COSpigs Date: $9-21-2016$

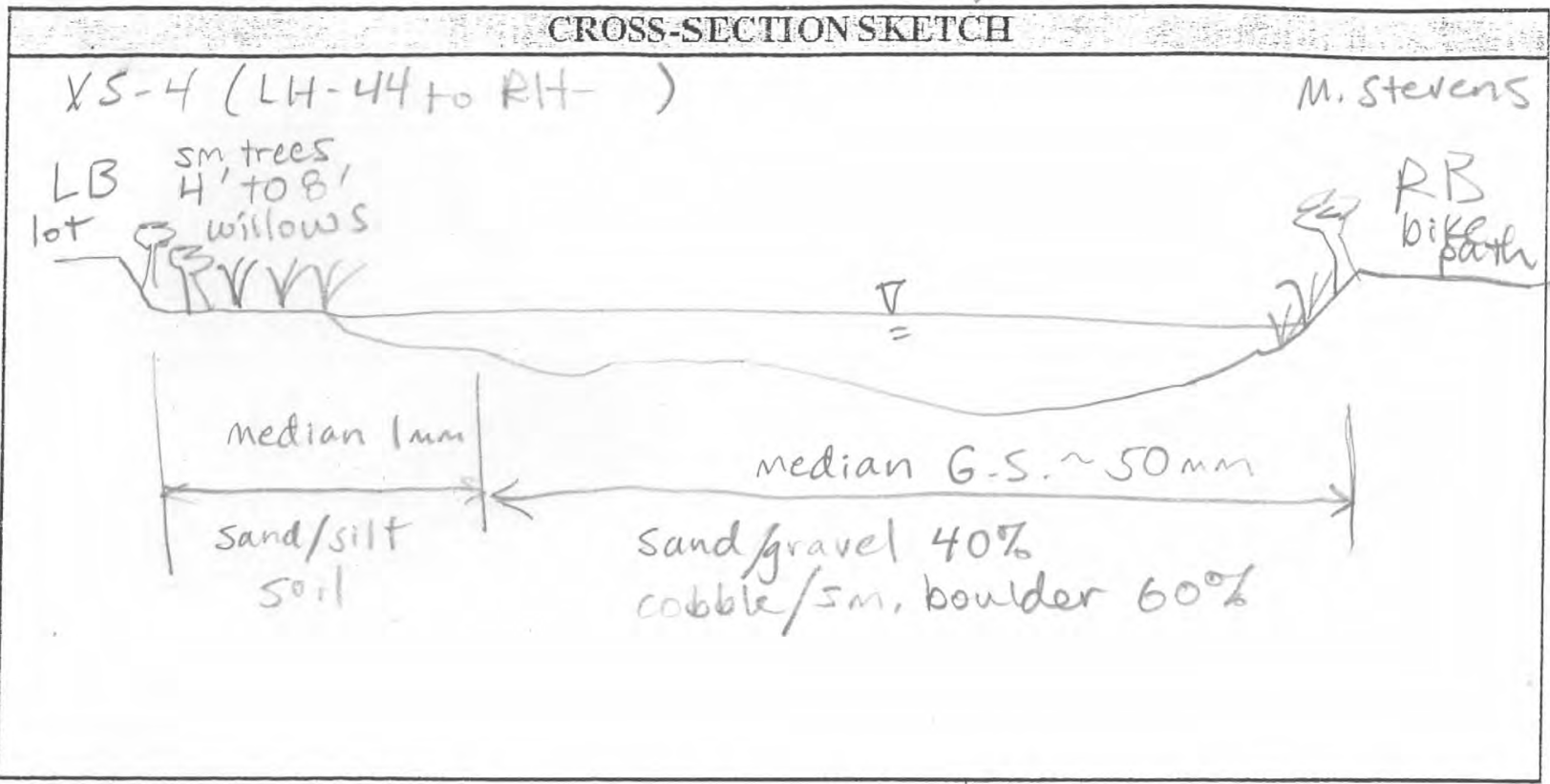

\begin{tabular}{|c|c|c|}
\hline Platers & A Assign main channel roughness & 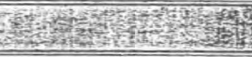 \\
\hline Factor & Description & Rouahness \\
\hline Base $(\mathrm{n} 0)$ & median 6.5. $\sim 50 \mathrm{~mm}$ & 0,032 \\
\hline Irregularity (n1) & moderate scalloping, eroded banks & 0,010 \\
\hline Variability (n2) & gradual & 0.000 \\
\hline Obstruction (n3) & negligible, sturpes/logs & 0.004 \\
\hline Vegetation (n4) & main channel $10 \%$ shrubs/smitrees & 0,002 \\
\hline Meandering (m) & minor & $\times 1.0$ \\
\hline & Total $=$ & 0.048 \\
\hline
\end{tabular}

\begin{tabular}{|c|c|c|c|c|c|}
\hline Shy & Ass & In flood-P & rough & What & Wis \\
\hline Subsection & $n(0)$ & $n(1)$ & $\underline{n(3)}$ & $n(4)$ & Total $n$ \\
\hline$\angle B$ & 0.025 & 0,004 & 0.005 & 0.030 & 0,064 \\
\hline & & & & & \\
\hline & & & & & \\
\hline & & & & & \\
\hline & & & & & \\
\hline & & & & & \\
\hline
\end{tabular}

Figure 9-4. The Manning roughness coefficient (n) assignments for cross section 4 on Fountain Creek below U.S. Highway 24 in Colorado Springs, Colorado. 


\section{Field Exercise - Roughness Assignment}

Site Name: Fountain Cr Janitell Rd, CO sprgs Date: $9-21-2016$

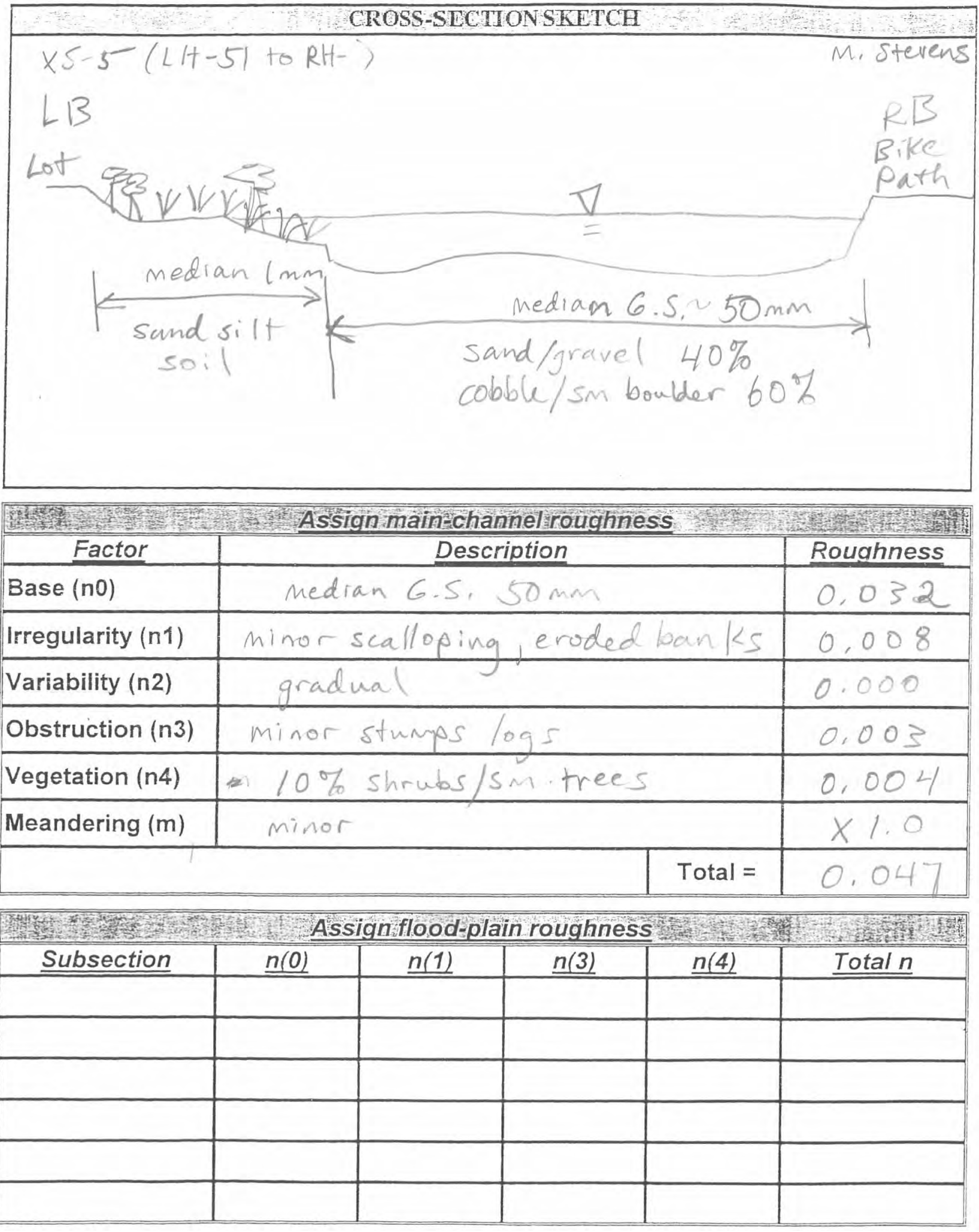

Figure 9-5. The Manning roughness coefficient (n) assignment for cross section 5 on Fountain Creek below U.S. Highway 24 in Colorado Springs, Colorado. 


\section{ROUGHNESS COEFFICIENTS \\ $n=m(n 0+n 1+n 2+n 3+n 4)$}

ASSIGN BASE ROUGHNESS (n0) VISUALIZE SIMPLE CHANNEL COMPOSED OF ONLY BED MATERIAL

\begin{tabular}{|c|c|c|c|}
\hline & & \multicolumn{2}{|c|}{ Base $n$ Value } \\
\hline Bed Material & $\begin{array}{l}\text { Median Size of bed material } \\
\text { (in millimeters) }\end{array}$ & Straight Uniform Channel & Smooth Channel \\
\hline \multicolumn{4}{|c|}{ Sand Channels } \\
\hline Sand ${ }^{3}$ & $\begin{array}{l}0.2 \\
.3 \\
.4 \\
.5 \\
.6 \\
.8 \\
1.0\end{array}$ & $\begin{array}{l}0.012 \\
.017 \\
.020 \\
.022 \\
.023 \\
.025 \\
.026\end{array}$ & $\begin{array}{l}-- \\
-- \\
-- \\
-- \\
--\end{array}$ \\
\hline \multicolumn{4}{|c|}{ Stable Channels and Flood Plains } \\
\hline $\begin{array}{l}\text { Concrete } \\
\text { Rock Cut } \\
\text { Firm Soil } \\
\text { Coarse Sand } \\
\text { Fine Gravel } \\
\text { Gravel } \\
\text { Coarse Gravel } \\
\text { Cobble } \\
\text { Boulder }\end{array}$ & $\begin{array}{l}-- \\
- \\
- \\
1-2 \\
- \\
2-64 \\
- \\
64-256 \\
>256\end{array}$ & $\begin{array}{l}0.012-0.018 \\
- \\
0.025-0.032 \\
0.026-0.035 \\
- \\
0.028-0.035 \\
- \\
0.030-0.050 \\
0.040-0.070\end{array}$ & $\begin{array}{l}0.011 \\
.025 \\
.020 \\
=- \\
.024 \\
-. \\
.026 \\
--\end{array}$ \\
\hline
\end{tabular}

ADJUST ROUGHNESS FOR CHANNEL IRREGULARITIES (n1)

\begin{tabular}{|l|l|l|}
\hline Channel Conditions & $n$ Value Adjustment & \multicolumn{1}{c|}{ Example } \\
\hline Degreb of Irregularity $\left(n_{1}\right)$ & 0.000 & $\begin{array}{l}\text { Compares to the smoothest channel attainable in a given bed } \\
\text { material. }\end{array}$ \\
\hline Smooth & $0.001-0.005$ & $\begin{array}{l}\text { Compares to carefully degraded channels in good condition but } \\
\text { having slightly eroded or scoured side slopes. }\end{array}$ \\
\hline Minor & $0.006-0.010$ & $\begin{array}{l}\text { Compares to dredged channels having moderate to } \\
\text { considerable bed roughness and moderately sloughed or } \\
\text { eroded side slopes. } \\
\text { sin rock. }\end{array}$ \\
\hline Severe & $\begin{array}{l}\text { Badly sloughed or scalloped banks of natural streams; badly } \\
\text { eroded or sloughed sides of canals or drainage channels; } \\
\text { unshaped, jagged, and irregular surfaces of channel }\end{array}$ \\
\hline
\end{tabular}

ADJUST ROUGHNESS FOR CROSS-SECTIONAL VARIATIONS (n2)

\begin{tabular}{|l|l|l|}
\hline Channel Conditions & $n$ Value Adjustment & \multicolumn{1}{c|}{ Example } \\
\hline Gradual & 0.000 & Size and shape of channel cross sections change gradually. \\
\hline Alternating occasionally & $0.001-0.005$ & $\begin{array}{l}\text { Large and small cross sections alternate occasionally, or the } \\
\text { main flow occasionally shifts from side to side owing to } \\
\text { changes in cross-sectional shape. }\end{array}$ \\
\hline Alternating frequently & $0.010-0.015$ & $\begin{array}{l}\text { Large and small cross sections alternate frequently, or } \\
\text { the main flow frequently shifts from side to side owing } \\
\text { to changes in cross-sectional shape. }\end{array}$ \\
\hline
\end{tabular}

Figure 9-6. The Manning roughness coefficient (n) assignment worksheet using the Cowan method, page 1 (Cowan, 1956). 
ADJUST ROUGHNESS FOR OBSTRUCTIONS (n3):

\begin{tabular}{|c|c|c|}
\hline Channel Conditions & nValue Adjustment & Example \\
\hline Negligible. & $0.000-0.004$ & $\begin{array}{l}\text { A few scattered obstructions, which include debris deposits, } \\
\text { stumps, exposed roots, logs, piers, or isolated boulders, that } \\
\text { occupy less than } 5 \text { percent of the cross-sectional area. }\end{array}$ \\
\hline Minor & $0.005-0.015$ & $\begin{array}{l}\text { Obstructions occupy less than } 15 \text { percent of the cross-sectional } \\
\text { area, and the spacing between obstructions is such that the } \\
\text { sphere of influence around one obstruction does not extend to } \\
\text { the sphere of influence around another obstruction. Smaller } \\
\text { adjustments are used for curved smooth-surfaced objects than } \\
\text { are used for sharp-edged angular objects. }\end{array}$ \\
\hline Appreciable & $0.020-0.030$ & $\begin{array}{l}\text { Obstructions occupy from } 15 \text { percent to } 50 \text { percent of the } \\
\text { cross-sectional area, or the space between obstructions is small } \\
\text { enough to cause the effects of several obstructions to be } \\
\text { additive, thereby blocking an equivalent part of a cross section. }\end{array}$ \\
\hline Severe & $0.040-0.050$ & $\begin{array}{l}\text { Obstructions occupy more than } 50 \text { percent of the } \\
\text { cross-sectional area, or the space between obstructions is small } \\
\text { enough to cause turbulence across most of the cross section. }\end{array}$ \\
\hline
\end{tabular}

ADJUST ROUGHNESS FOR VEGETATION (n4)

\begin{tabular}{|c|c|c|}
\hline Channel Conditions & n Value Adjustment & Example \\
\hline Small & $0.002-0.010$ & $\begin{array}{l}\text { Dense growths of flexible turf grass, such as Bermuda, or } \\
\text { weeds growing where the average depth of flow is at least two } \\
\text { times the height of the vegetation; supple tree seedlings such } \\
\text { as willow, cottonwood, arrowhead, or saltcedar growing where } \\
\text { the average depth of flow is at least three times the height of the } \\
\text { vegetation. }\end{array}$ \\
\hline Medium & $0.010-0.025$ & $\begin{array}{l}\text { Turf grass growing where the average depth of flow is from one } \\
\text { to two times the height of the vegetation; moderately dense } \\
\text { stemy grass, weeds, or tree seedlings growing where the } \\
\text { average depth of flow is from two to three times the height of } \\
\text { the vegetation; brushy, moderately dense vegetation, similar to } \\
1 \text {-to-2-year-old willow trees in the dormant season, growing } \\
\text { along the banks, and no significant vegetation is evident along } \\
\text { the channel bottoms where the hydraulic radius exceeds } 0.61 \\
\text { meters. }\end{array}$ \\
\hline Large & $0.025-0.050$ & $\begin{array}{l}\text { Turf grass growing where the average depth of flow is about } \\
\text { equal to the height of the vegetation; } 8 \text {-to-10-years-old willow or } \\
\text { cottonwood trees intergrown with some weeds and brush (none } \\
\text { of the vegetation in foliage) where the hydraulic radius } \\
\text { exceedso.60 m; bushy willows about } 1 \text { year old intergrown with } \\
\text { some weeds along side slopes (all vegetation in full foliage), } \\
\text { and no significant vegetation exists along channel bottoms } \\
\text { where the hydraulic radius is greater than } 0.61 \text { meters. }\end{array}$ \\
\hline Very Large & $0.050-0.100$ & $\begin{array}{l}\text { Turf grass growing where the average depth of flow is less than } \\
\text { half the height of the vegetation; bushy willow trees about } 1 \\
\text { year old intergrown with weeds along side slopes C all } \\
\text { vegetation in full foliage). or dense cattails growing } \\
\text { along channel bottom; trees intergrow with weeds and brush } \\
\text { (all vegetation in full follage). }\end{array}$ \\
\hline
\end{tabular}

ADJUST ROUGHNESS FOR MEANDERING (m)

\begin{tabular}{|c|c|c|}
\hline Channel Conditions & n Value Adjustment & Example \\
\hline Minor & 1.00 & $\begin{array}{l}\text { Ratio of the channel length } \\
\text { to valley length is } 1.0 \text { to } 1.2 \text {. }\end{array}$ \\
\hline Appreciable & 1.15 & $\begin{array}{l}\text { Ratio of the channel length } \\
\text { to valley length is } 1.2 \text { to } 1.5 \text {. }\end{array}$ \\
\hline Severe & 1.30 & $\begin{array}{l}\text { Ratio of the channel length } \\
\text { to valley length is greater } \\
\text { than } 1.5 \text {. }\end{array}$ \\
\hline
\end{tabular}

Figure 9-7. The Manning roughness coefficient (n) assignment worksheet using the Cowan method, page 2 (Cowan, 1956). 
Appendix 10. Plots Showing the Cross Sections with Manning Roughness Coefficients (n) Assignments for Fountain Creek below U.S. Highway 24 in Colorado Springs, Colorado

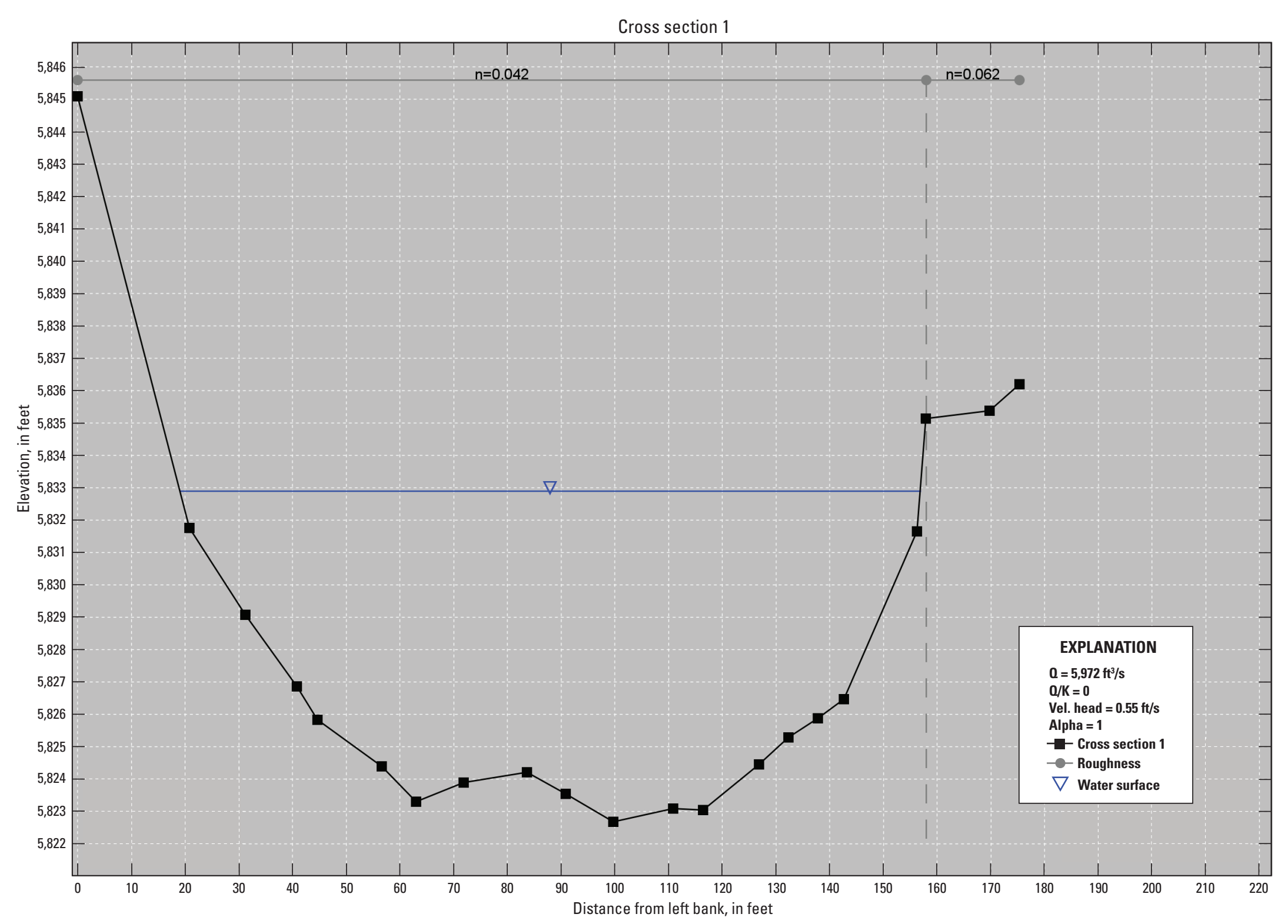

Figure 10-1. Cross section 1 with the Manning roughness coefficient (n) assignment for Fountain Creek below U.S. Highway 24 in Colorado Springs, Colorado; generated from the Slope-Area Computation Graphical User Interface. [X1, cross section 1; 0, discharge; ft3/s, cubic foot per second; K, conveyance; Vel., velocity; ft/s, foot per second] 


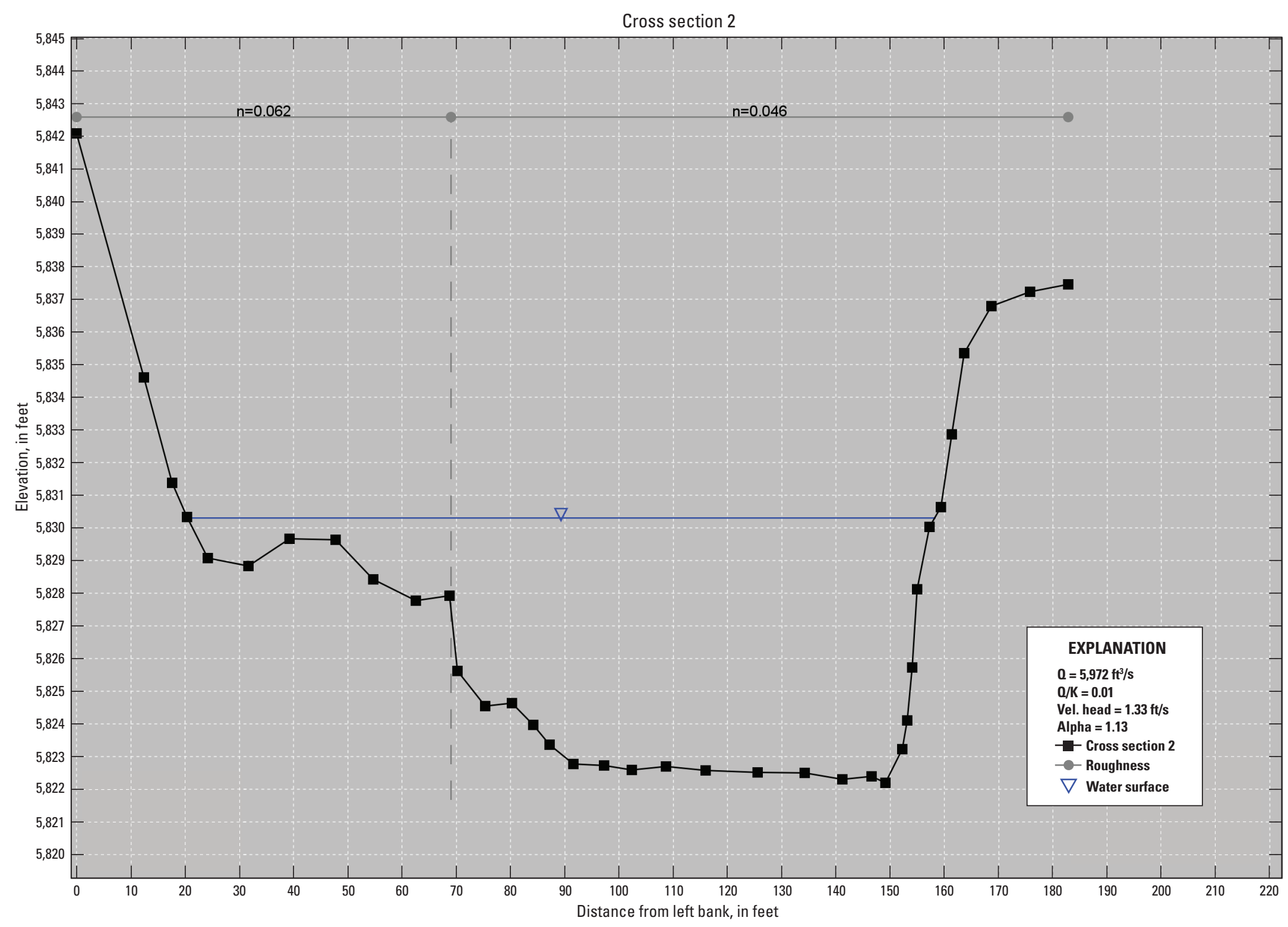

Figure 10-2. Cross section 2 with the Manning roughness coefficient ( $\mathrm{n}$ ) assignment for Fountain Creek below U.S. Highway 24 in Colorado Springs, Colorado; generated from the Slope-Area Computation Graphical User Interface. [X2, cross section 2; 0, discharge; $\mathrm{ft}^{3} / \mathrm{s}$, cubic foot per second; $\mathrm{K}$, conveyance; Vel., velocity; $\mathrm{ft} / \mathrm{s}$, foot per second] 


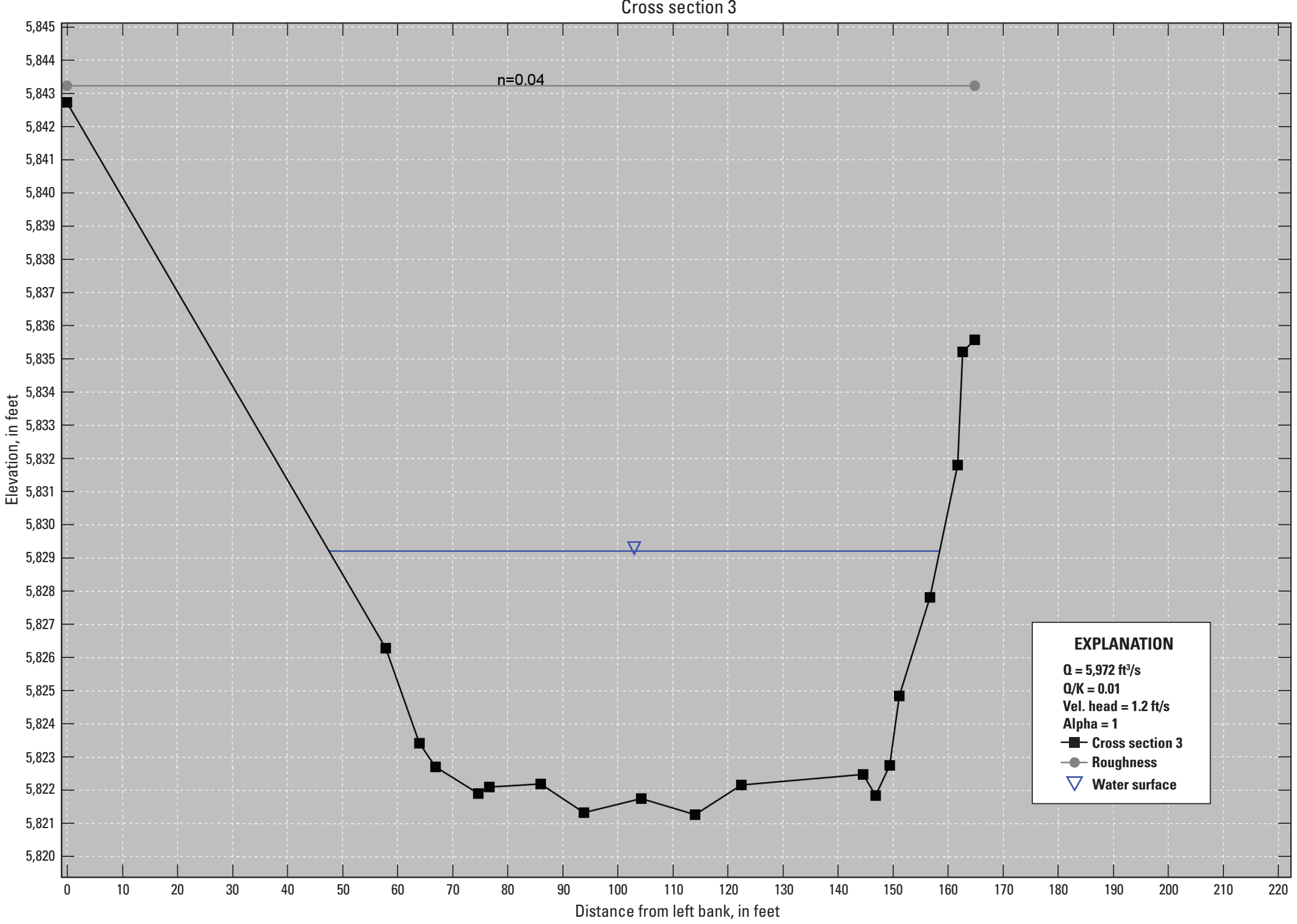

Figure 10-3. Cross section 3 with the Manning roughness coefficient (n) assignment for Fountain Creek below U.S. Highway 24 in Colorado Springs, Colorado; generated from the Slope-Area Computation Graphical User Interface. [X3, cross section 3; 0, discharge; ft3/s, cubic foot per second; $\mathrm{K}$, conveyance; Vel., velocity; ft/s, foot per second] 


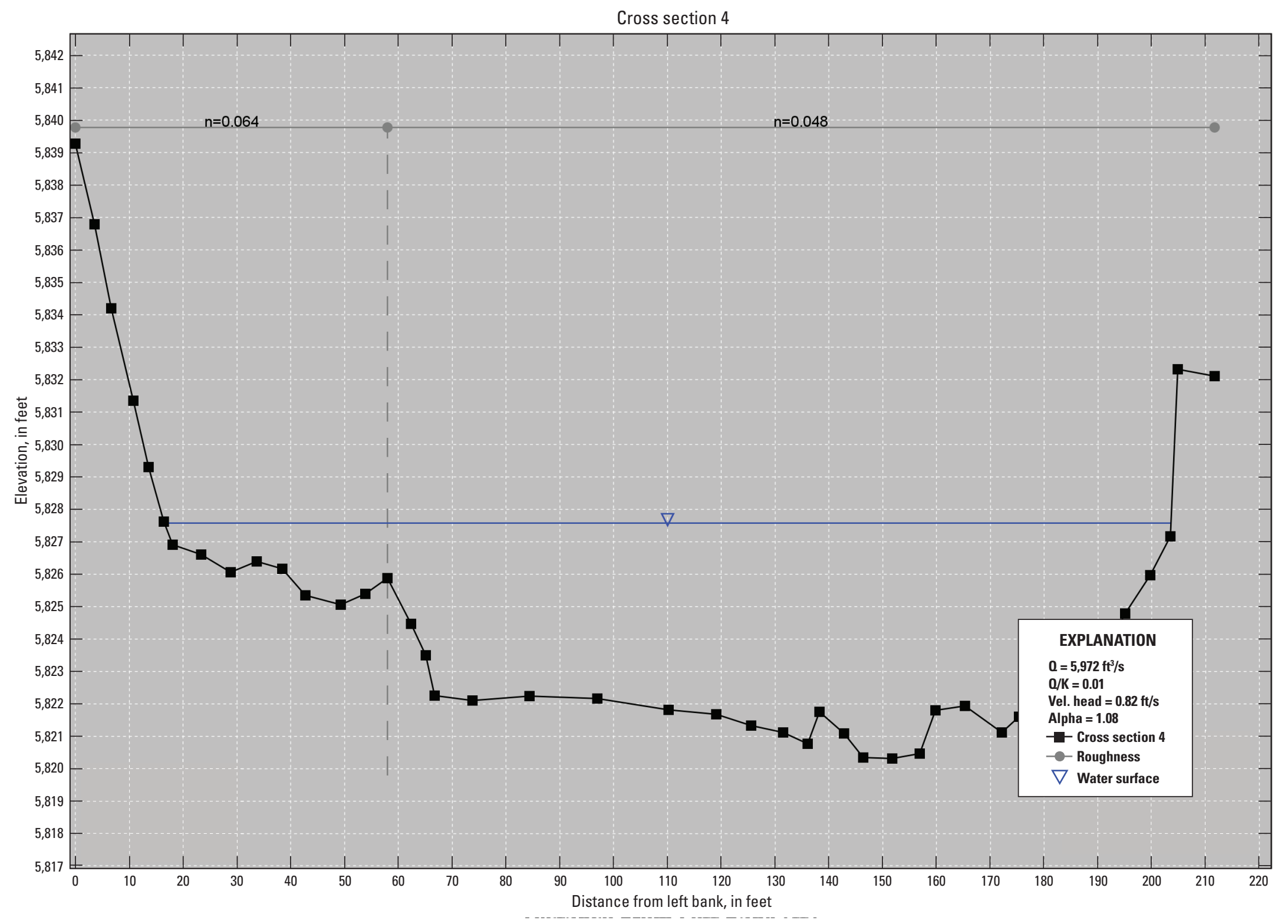

Figure 10-4. Cross section 4 with the Manning roughness coefficient ( $\mathrm{n}$ ) assignment for Fountain Creek below U.S. Highway 24 in Colorado Springs, Colorado; generated from the Slope-Area Computation Graphical User Interface. [X4, cross section 4; Q, discharge; fts/s, cubic foot per second; K, conveyance; Vel., velocity; ft/s, foot per second] 


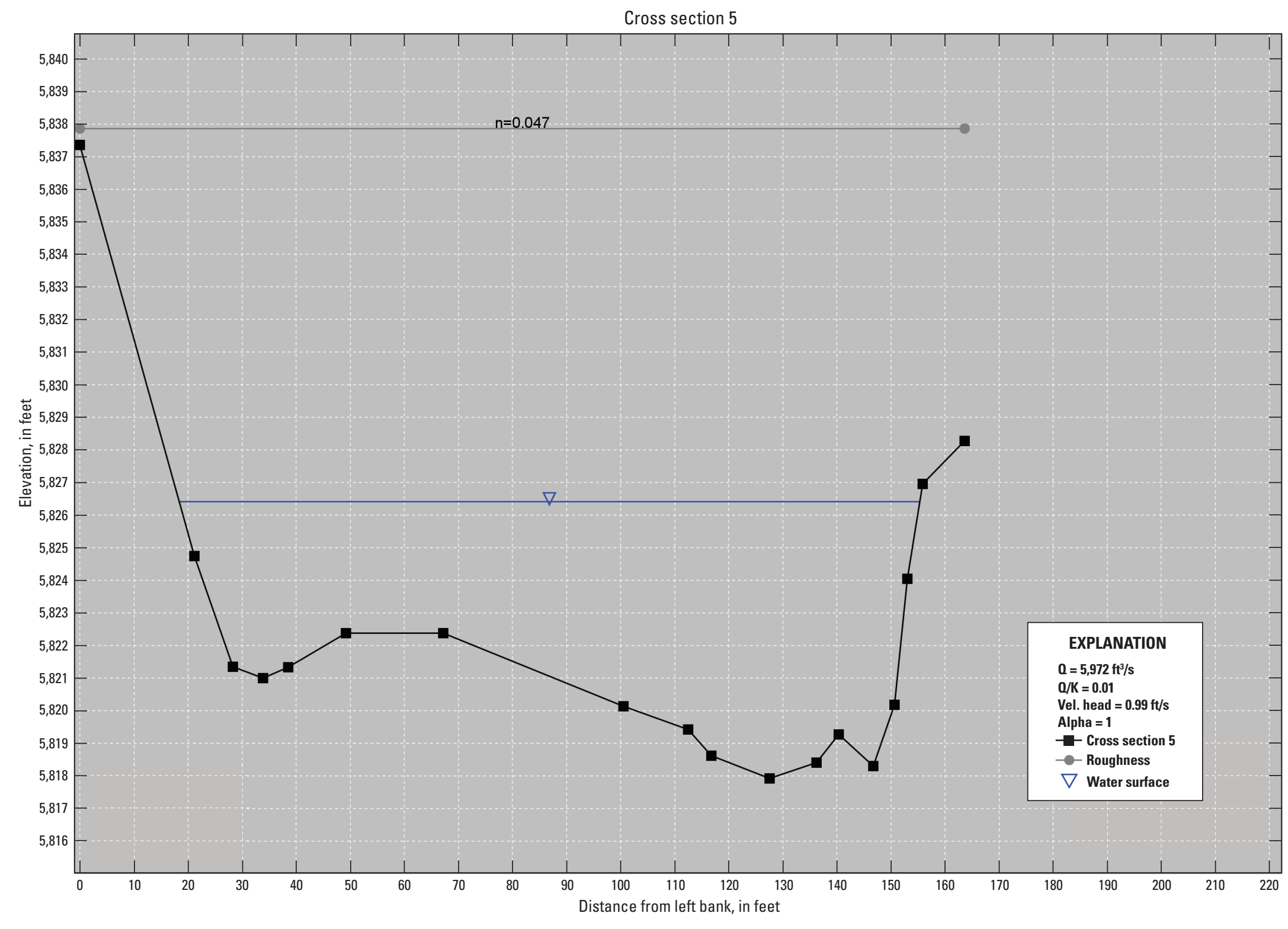

Figure 10-5. Cross section 5 with the Manning roughness coefficient (n) assignment for Fountain Creek below U.S. Highway 24 in Colorado Springs, Colorado; generated from the Slope-Area Computation Graphical User Interface. [X5, cross section 5; 0 , discharge; ft3/s, cubic foot per second; $\mathrm{K}$, conveyance; Vel., velocity; ft/s, foot per second] 
Publishing support provided by Denver Publishing Service Center

For more information concerning this publication, contact Director, USGS Colorado Water Science Center

Box 25046, Mail Stop 415

Denver, CO 80225

(303) 236-4882

Or visit the Colorado Water Science Center website at https://co.water.usgs.gov/ 


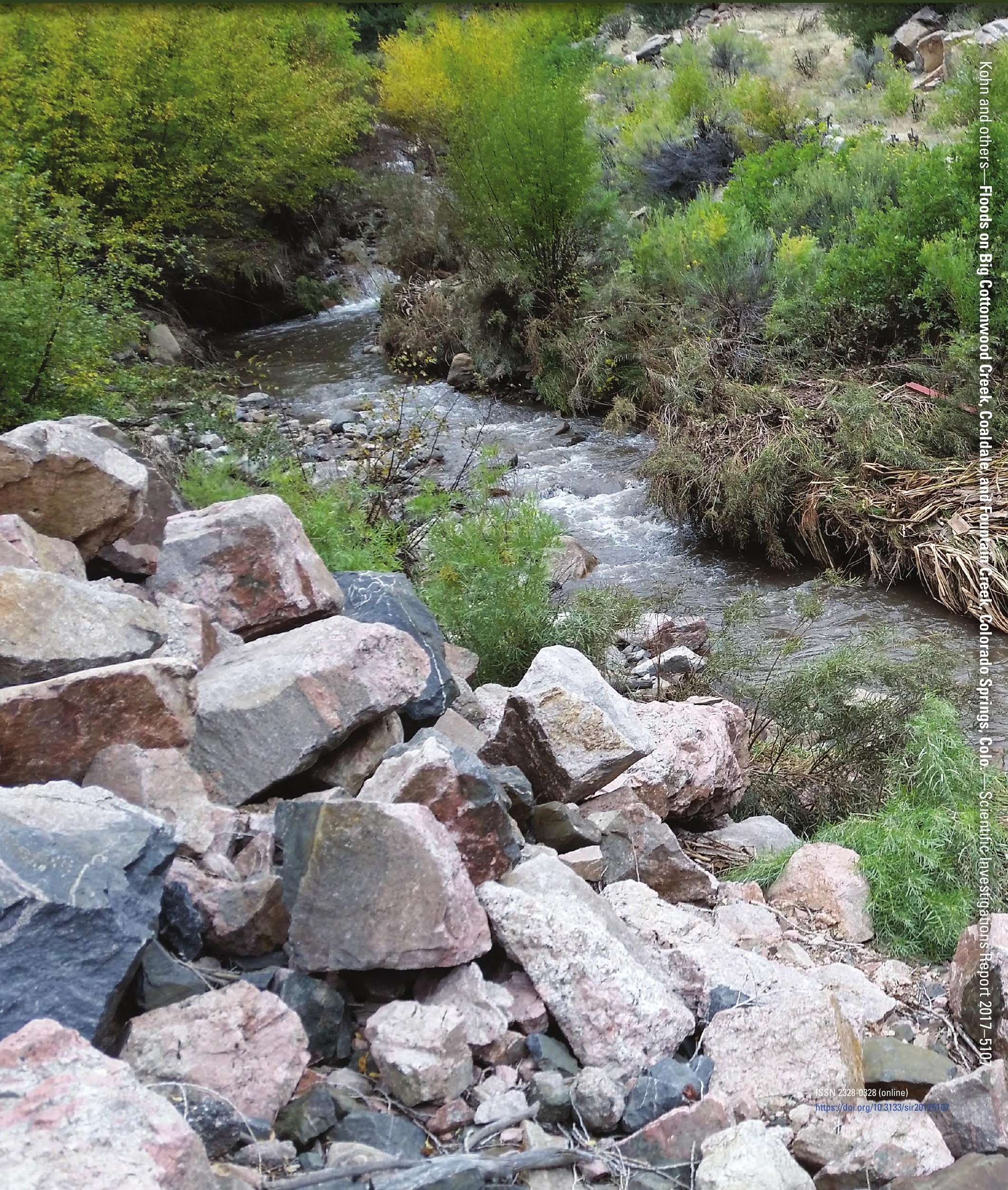

